\title{
THE STRATIGRAPHY OF THE MONTANA GROUP, WITH SPECIAL REFERENCE TO THE POSITION AND AGE OF THE JUDITH RIVER FORMATION IN NORTH-CENTRAL MONTANA.
}

By C. F. Bowen.

\section{INTRODUCTION.}

The differences of opinion which have arisen regarding the stratigraphic position and age of the Judith River formation led the writer to undertake a study of the Montana group in order to determine, if possible, the stratigraphic relation of this formation. Stanton and Hatcher had previously announced that the Judith River formation is of Cretaceous age. Although at first this conclusion was generally accepted, doubt has since arisen as to its correctness. The investigations of the writer were therefore begun in an area where the formations are well exposed and where the stratigraphic succession can be established beyond doubt. From this area the formations were traced northward to Missouri River in the type locality of the Judith River formation. This study has demonstrated the correctness of Stanton and Hatcher's views and forms the basis of the present paper.

The area here discussed lies east of the Big Snowy and Judith mountains and extends from Musselshell, on Musselshell River, to Judith, on Missouri River, Mont. The geographic location of the area is shown by the key map on Plate X.

The investigation, which was of a reconnaissance character, was undertaken to ascertain the coal resources of this area and to make a special study of the stratigraphy of the formations of Montana age which are exposed in this part of the State. In this work the writer was assisted by Harvey Bassler, T. K. Harnsberger, and J. R. Jaquet. The economic results of the investigation have already been published. ${ }^{1}$

In the preparation of this paper the writer has made free use of all previously published information, for which credit is given in the proper places. He is especially indebted to Messrs. C. W. Gilmore, J. W. Gidley, O. P. Hay, F. H. Knowlton, and T. W. Stanton for assistance rendered in the preparation and arrangement of the paleontologic data. Inasmuch as the writer is not a paleontologist, it is proper to state here that the remarks regarding the synonymy and the validity of the determination of certain of the species of vertebrates have been extracted largely from the writings of E. D. Cope, J. B. Hatcher, O. P. Hay, L. M. Lambe, R. S. Lull, and H. F. Osborn and have been approved by C. W. Gilmore.

\section{PREVIOUS WORK.}

Since 1853, when Hayden did his first work on the upper part of Missouri River, many observers have contributed to the discussion of the stratigraphic position of the Judith River and underlying formations. Most of these early observers, including Hayden, Meek, Cope, C. A. White, and Peale, studied the section along Missouri River but did not attempt detailed mapping of the individual formations. In recent years more detailed work has been done in this and adjacent areas by Stanton and Hatcher, ${ }^{2}$ Calvert, ${ }^{3}$ and Lupton. ${ }^{4}$

\footnotetext{
${ }^{1}$ Bowen, C. F., Coal discovered in a reconnaissance survey between Musselshell and Judith, Montana: U. S. Geol. Survey Bull. 541, pp. 329337,1914 .

2 Stanton, T. W., and Hateher, J. B., Geology and paleontology of the Judith River beds: U. S. Geol. Survey Bull. 257, 1905.

3 Calvert, W. R., Geology of the Lewistown coal field, Montana: U. S. Geol. Survey Bull. 390, 1909.

${ }^{4}$ Lupton, C. T., The eastern part of the Bull Mountain coal field, Montana: U. S. Geol. Survey Bull. 431, pp. 163-189, 1911.
} 


\section{BASE MAP AND FIELD METHOD.}

The United States Geological Survey is preparing a map of the United States for publication on a scale of about 16 miles to the inch. Part of this map was enlarged to a scale of 4 miles to the inch and used as the base for the geologic map (Pl. X). The land lines and the drainage on this map are fairly accurate. The slight discrepancies which occur are so small that they do not appreciably affect the accuracy of the map on the scale on which it is here published, and therefore no adjustments were made.

Horizontal control for the geologic mapping was based on township surveys of the General Land Office. A main stadia traverse tied to land corners, generally not less than once in each township, was carried throughout the area, this part of the work being done with a Johnson plane table and a Gale telescopic alidade. Side lines, tied to the main traverse and to land corners, were made by horse pacing and by triangulation, with a 15-inch plane table and an open-sight alidade. By these methods the structure was platted and the boundaries of the formations were mapped. On the map thus prepared (Pl. X) the portions of the boundaries that were located with considerable accuracy are represented by solid lines and the portions that were located only approximately are represented by broken lines.

\section{STRATIGRAPHY.}

GENERAL SECTION.

The formations represented in the area here considered are the Colorado shale, Eagle sandstone, Claggett formation, Judith River formation, and Bearpaw shale, of Upper Cretaceous age, and the Lance formation, of Tertiary (?) age. The geologic age and stratigraphic relations of the Eagle, Claggett, Judith River, and Bearpaw formations in north-central Montana were worked out by Stanton and Hatcher ${ }^{1}$ in 1903 , but Peale ${ }^{2}$ in a recent article dissents from the conclusions they reached. The sequence, thickness, and characteristics of these formations, as determined by the studies of the writer in this field, are shown in the following generalized section:

Generalized section of the sedimentary rocks in the area between Judith and Musselshell, Mont.

\begin{tabular}{|c|c|c|c|c|}
\hline $\begin{array}{l}\text { System and } \\
\text { series. }\end{array}$ & Group. & Formation. & Characteristics. & $\begin{array}{l}\text { Thickness } \\
\text { (feet). }\end{array}$ \\
\hline $\begin{array}{l}\text { Tertiary(?), Eo- } \\
\text { cene(?). }\end{array}$ & & $\begin{array}{l}\text { Lance forma- } \\
\text { tion. }\end{array}$ & Alternating gray sandstone and clay shale, with thin beds of coal near the top. $a$ & $700-800$ \\
\hline \multirow{4}{*}{$\begin{array}{l}\text { Cretaceous (Up- } \\
\text { per Cretace- } \\
\text { ous). }\end{array}$} & \multirow{4}{*}{ Montana. } & $\begin{array}{l}\text { B e arp a w } \\
\text { shale. }\end{array}$ & $\begin{array}{l}\text { Marine shale, dark gray to black in upper part but with greenish tinge in lower } \\
\text { part in southern portion of the field; contains numerous calcareous concre- } \\
\text { tions which yield Baculites ovatus, Baculites compressus, Scaphites nodosus, } \\
\text { Inoceramus barabini, and other species characteristic of the Pierre shale. }\end{array}$ & $1,100 \pm$ \\
\hline & & $\begin{array}{l}\text { Judith River } \\
\text { formation. }\end{array}$ & $\begin{array}{l}\text { Alternating beds of sandstone, clay, and shale, including carbonaceous mem- } \\
\text { bers, mainly of brackish or fresh water origin. In the northern part of the } \\
\text { area a more or less persistent coal bed occurs near the top of the formation } \\
\text { and is in most places overlain by a bed of marl or breccia, containing great } \\
\text { numbers of Ostrea subtrigonalis. The formation also contains bones of verte- } \\
\text { brates, fragments of leaves and stems, and much silicified wood. }\end{array}$ & $250-500$ \\
\hline & & \multirow[t]{2}{*}{$\begin{array}{l}\text { Claggett for- } \\
\text { mation. }\end{array}$} & $\begin{array}{l}\text { An upper division consisting of alternating beds of sandstone and shale, becom- } \\
\text { ing predominantly sandstone at top. Marine fossils occur in these sandstones } \\
\text { along Missouri and Judith rivers but have not yet been found in the south- } \\
\text { ern part of the area. The common forms are Tancredia americana, Cardium } \\
\text { speciosum, Mactra formosa, Mactra alta, and other species formerly considered } \\
\text { as characteristic of the Fox Hills sandstone. }\end{array}$ & $200 \pm$ \\
\hline & & & $\begin{array}{l}\text { A lower division of dark marine shale which can not be easily distinguished } \\
\text { lithologically or paleontologically from the Bearpaw shale. The most com- } \\
\text { mon fossils are Baculites ovatus, Baculites compressus, Gervillia borealis, Ino- } \\
\text { ceramus barabini, and Leda evansi-species characteristic of the Pierre shale. }\end{array}$ & $500 \pm$ \\
\hline
\end{tabular}

$a$ Lupton, C. T., The eastern part of the Bull Mountain coal field, Montana: U. S. Geol. Survey Bull. 431, pp. 169-170, 1911.

1 Op. cit., p. 63.

2 Peale, A. C., On the stratigraphic position and age of the Judith River formation: Jour. Geology, vol. 20, pp. 530-549, 640-652, 738-757, 1912. 
Generalized section of the sedimentary rocks in the area between Judith and Musselshell, Mont.-Continued.

\begin{tabular}{|c|c|c|c|c|}
\hline $\begin{array}{l}\text { System and } \\
\text { series. }\end{array}$ & Group. & Formation. & Characteristics. & $\begin{array}{l}\text { Thickness } \\
\text { (feet). }\end{array}$ \\
\hline \multirow{3}{*}{$\begin{array}{l}\text { Cretaceous } \\
\text { (Upper Cre- } \\
\text { taceous)- } \\
\text { Continued. }\end{array}$} & \multirow{2}{*}{$\begin{array}{l}\text { Montana-Con- } \\
\text { tinued. }\end{array}$} & \multirow{2}{*}{$\begin{array}{l}\text { Eagle s a n d - } \\
\text { stone. }\end{array}$} & $\begin{array}{l}\text { In the northern part of the field the upper member of the Eagle sandstone con- } \\
\text { sists of thin-bedded sandstone with some interbedded shale, and the middle } \\
\text { member consists principally of dark-colored shale in which there are a few } \\
\text { thin beds of carbonaceous shale, coal, and sandstone. In the southern part } \\
\text { of the field the middle member consists of thin-bedded shaly sandstone and } \\
\text { contains no coal or carbonaceous beds. }\end{array}$ & $100-180$ \\
\hline & & & $\begin{array}{l}\text { Virgelle sandstone member, a massive to heavy bedded sandstone which is } \\
\text { highly cross-bedded in some places. In the northern part of the field it is } \\
\text { prevailingly of a white color and contains numerous small rusty concretions. } \\
\text { In the southern part of the field the color is gray to light brown. It forms } \\
\text { conspicuous ledges or hogback ridges wherever exposed. }\end{array}$ & $100-120$ \\
\hline & & $\begin{array}{l}\text { C o l or a d o } \\
\text { shale. }\end{array}$ & $\begin{array}{l}\text { In its upper part the Colorado is a black marine shale, alternating with thin } \\
\text { beds of sandy shale and sandstone. At one locality examined a calcareous } \\
\text { fossiliferous sandstone occurs in the upper part of the formation. The lower } \\
\text { part of the formation was not studied. Baculites sp., Dosinia orbiculata, } \\
\text { Gyrodes conradi, Inoceramus deformis, Inoceramus labiatus, Scaphites ventri- } \\
\text { cosus, and other forms were obtained from this formation. }\end{array}$ & Not measured. \\
\hline
\end{tabular}

\section{CRETACEOUS SYSTEM.}

COLORADO SHALE.

Position and character.-Conformably beneath the Montana group lies black laminated shale in which are thin beds of arenaceous material. The shale at several localities has yielded fossils which T. W. Stanton has pronounced of Colorado age.

Distribution and topographic expression.-The Colorado shale is somewhat widely distributed to the west and south of the area mapped, where it is exposed around the anticline of the Big Snowy Mountains. From Willow Creek, in the southern part of this field, to the North Moccasin Mountains the shale is well exposed immediately beneath the Montana group, and at two localities it occurs as an inlier, brought up by subordinate folds, within the area occupied by the younger rocks. Because of its slightly resistant character the shale is easily eroded and occupies valleys bordered by the more resistant beds of overlying sandstone.

Relation to overlying formations.-The Colorado shale lies conformably beneath the Eagle sandstone and is separated from the typical sandstone by a transitional zone of sandy shale. The boundary between the two formations was drawn at the top of the transitional'zone, because this horizon marks the most abrupt lithologic change and is most easily recognized in the field.

\section{EAGLE SANDSTONE.}

Definition.-The name Eagle sandstone was given by Weed ${ }^{1}$ to the formation overlying the Colorado shale in north-central Montana and typically exposed on Missouri River at the mouth of Eagle Creek, 40 miles below Fort Benton. In the type locality the formation as defined by Weed consists of three more or less distinct units, comprising an upper member of thin-bedded sandstone, a middle member of shale, and a lower member of massive ledge-making sandstone. This lower member is so persistent and characteristic over a large area in northcentral Montana, even where the other divisions of the formation are not recognizable, that it seems desirable for purposes of description and correlation to give it a name. It is well exposed along Missouri River from the town of Virgelle, a few miles below Fort Benton, eastward, and the name Virgelle sandstone member of the Eagle sandstone has therefore been adopted by the United States Geological Survey for this division of the formation. The Virgelle sandstone member is the lower massive ledge-making sandstone of the Eagle sandstone as defined by Weed.

According to Stanton and Hatcher, the Eagle sandstone constitutes the lowest formation of the Montana group, and the fossils collected from it by the writer have been determined by Mr. Stanton to be of Montana age. 
Character and thickness.-In the southern part of the field the Virgelle sandstone member of the Eagle consists of a dull-gray to brownish massive, ledge-making sandstone about 100 feet thick; the middle division of the Eagle is a thin-bedded shaly sandstone; and the upper division is a thick-bedded, resistant sandstone in which large rusty-brown concretions are locally very numerous. As the formation is traced northward a change in the lithologic character may be noted about 12 miles east of Black Butte, where carbonaceous beds and thin streaks of coal begin to appear in the middle division of the formation. From Black Butte westward thin beds of carbonaceous shale and coal occur in this part of the formation at several places, and near Deerfield (about 8 miles southwest of the area mapped on Pl. X) coal is being mined from a bed which, according to descriptions given by residents, overlies the Virgelle sandstone member. On Missouri River the formation shows still further changes in lithology; the Virgelle sandstone member is glistening white to dull white in color, the middle division of the formation has changed to dark shale containing several thin beds of coal, and the upper division consists of thin-bedded sandstone and sandy shale.

The total thickness of the Eagle sandstone ranges from 200 feet in the southern part of the field to 250 or 300 feet on Missouri River.

Distribution and topographic expression.-The Eagle sandstone occupies a narrow belt overlying the Colorado shale from Willow Creek to the North Moccasin Mountains. West of these mountains (beyond the area mapped) it is more widespread, because of the decrease in the dip of the beds. The formation is also exposed at several places on Judith and Missouri rivers north of Fullerton. In these places it has been brought up by faulting.

From Willow Creek north to Boxelder Creek the Eagle sandstone forms ledges 25 to 100 feet high. Throughout the rest of the area the beds are inclined at angles of $20^{\circ}$ to $70^{\circ}$ and the formation produces narrow ridges with sandstone ribs along their crests. A characteristic topographic feature of the Eagle is a double ridge, formed by the sandstones of the upper and lower divisions of the formation, separated by a shallow depression that is occupied by the more easily eroded beds of the middle division.

Because of its ledge-making habit, the Eagle sandstone is well exposed and easily traced throughout the area, except on the north side of the Judith and North Moccasin mountains, where it is partly obscured by gravel washed down from the mountains.

Relation to Claggett formation and correlation.-The Eagle is conformable with the overlying Claggett formation, from which it is distinguished by its lithologic character. The correlation of the Eagle on Missouri River with that mapped from the North Moccasin Mountains to the south side of the field is rendered certain because of its stratigraphic position, between the Colorado shale below and the shale of the Claggett formation above.

\section{CLAGGETT FORMATION.}

The name Claggett was given by Stanton and Hatcher ${ }^{1}$ to the formation overlying the Eagle sandstone because the formation is well exposed in the neighborhood of Judith (old Fort Claggett), on Missouri River, which therefore becomes the type locality. As originally defined, the Claggett is separable into two divisions-a lower one of shale and an upper one consisting predominantly of sandstone. This definition will be followed in the present paper, though the writer believes that the upper division belongs more naturally to the Judith River formation.

Character and thickness.- The lower division of the Claggett consists of dark marine shale similar both lithologically and paleontologically to the Bearpaw shale, which will be described later. It is about 750 feet thick in the southern part of the field, as determined by stadia measurement. Just north of Fullerton, on Judith River, an aneroid measurement gave a thickness of about 500 feet, and at this locality the upper division is about 120 feet thick.

The upper division consists of alternating beds of sandstone and shale, becoming predominantly sandstone in the upper part. At the top there is a bed of massive rusty-brown sandstone ranging from 1 foot to 20 feet in thickness. These beds were included in the Claggett by Stanton and Hatcher because they contain a marine fauna.

1 Stanton, T. W., and Hatcher, J. B., Geology and paleontology of the Judith River beds: U. S. Geol. Survey Bull. 257, p. 13, 1905. 
The dark shale constituting the lower division of the Claggett contains Baculites ovatus, Baculites compressus, Inoceramus barabini, Leda evansi, and other forms characteristic of the Pierre shale, most of which also occur in the Bearpaw shale. At the type locality of the Claggett its upper division contains Cardium speciosum, Mactra alta, Mactra formosa, Tancredia americana, and some other forms, all marine types, many of which occur in the Fox Hills sandstone. This fauna led the earlier geologists to assign the beds to the Fox Hills.

Distribution and topographic expression.-The surface distribution of the Claggett is shown on the accompanying map (Pl. X). Along the southern margin of the field and also along the north side nearly as far west as Black Butte the outcrop of the formation is very narrow, because the dip of the beds is steep. West of Black Butte the dip gradually decreases and the width of outcrop increases, so that north of the North Moccasin Mountains the formation is very widespread. Its western boundary was not mapped in this part of the field, but a complete section of the formation is exposed in the valley of Judith River between a point a few miles north of Deerfield and Missouri River.

The soft shale of the lower division of the Claggett is easily eroded and generally occupies a depression between the ridges formed by the underlying Eagle sandstone and the overlying sandstone of the upper division of the Claggett and the Judith River. The formation is in general well exposed throughout the area described, but along the north side of the Judith and North Moccasin mountains the exposures are not so good, the formation being covered in places by gravel washed down from the mountains. There is also a narrow gap in the outcrop north of Boxelder Creek, where the Claggett has been eroded from the axis of the Cat Creek anticline.

The lower division of the Claggett is easily recognized and traced in the field, because of its lithologic character and its effect on the topography. The upper division is less readily recognized and traced, because of its resemblance to the Judith River formation, which it immediately underlies, but north of the North Moccasin Mountains it is very prominent in the upper part of the bluffs of the Judith River valley and is identified by the marine fossils which it contains. East of the North Moccasin Mountains no fossils were found in this division of the formation, but it was recognized in many places, notably south of Flat Willow Creek, by its rusty-brown color and its resistance to erosion, because of which it forms a cap protecting the underlying softer rocks.

Relation to other formations. - The gradual transition from the marine Claggett to the overlying fresh-water Judith River formation is adequately expressed by the following quotation from Stanton and Hatcher. ${ }^{1}$ Describing the exposures on Dog Creek, they say:

For considerable distances the Judith River beds are nearly or quite horizontal and conformably overlie the Claggett formation in such a manner that it is difficult to determine where one formation ends and the other begins, although in the field a bed of yellowish-brown sandstone varying in thickness from 1 foot to 20 feet or more was regarded as the upper limit of the Claggett formation. *** From the persistence of this sandstone and from the fact that it marked the beginning of a decided change in the lithology of the underlying and overlying beds, it would certainly form a convenient delimitation between the two series of deposits and should perhaps be considered as the uppermost member of the Claggett formation, notwithstanding that in a number of instances typically marine fossils extended for some distance above in the basal members of those lighter-colored sandstones and shales usually referred to the Judith River beds and generally considered as entirely of fresh or brackish water origin.

Cope's observations also agree with those of Stanton and Hatcher. He says: ${ }^{2}$

From what has preceded the general conclusion is reached that the series of beds from the lowest of the Fort Pierre epoch to the summit of the Judith River is continuous and uninterrupted by any nonconformity or hiatus. They appear to have been deposited in regular sequence, and without any other disturbance than that oscillation of the bed of the sea which causes change in the character of the sediment.

On the other hand, Peale ${ }^{3}$ says that there is a suggestion of an unconformity between the upper division of the Claggett (called Fox Hills by him) and the Judith River beds in the valley of Judith River below Fullerton.

1 Stanton, T. W., and Hatcher, J. B., op. cit., p. 36

2 Cope, E. D., Report on the geology of the region of the Judith River, Montana, and on vertebrate fossils obtained on or near the Missouri River: U.S. Geol. and Geog. Survey Terr. Bull. 3, p. 574, 1877.

${ }^{3}$ Peale, A. C., On the stratigraphic position and age of the Judith River formation: Jour. Geology, vol. 20, p. $543,1912$. 
The writer's observations agree with those of Stanton and Hatcher and those of Cope. He was unable to detect any evidence of unconformity either between the Claggett and Judith River formations or at any other horizon in the section from the Colorado shale up to and including the Lance formation. $\mathrm{He}$ is of the opinion, however, that the upper division of the Claggett more properly belongs with the Judith River formation. Stanton and Hatcher included this upper division in the Claggett formation because it contains a marine fauna, but the preceding quotation from them shows that there is no sharp line of demarkation either in lithology or paleontology between it and the overlying fresh-water beds. On the other hand, there is a rather marked lithologic change between the upper and lower divisions of the Claggett. Furthermore, in the southern part of this field no marine fossils have been found in the upper division of the Claggett formation, and therefore the distinction between Claggett and Judith River as at present defined is even less marked here than on Missouri River. In fact, in the southern part of the field it is not practicable to separate the sandstone that has been included in the Claggett formation from the Judith River formation. Similarly, 35 miles northwest of the mouth of Judith River, in the Big Sandy coal field, where the same formations are involved, no marine fossils occur in the sandstone immediately overlying the shale of the Claggett formation. Instead of containing marine fossils the sandstones, which there seem to be the equivalent of the upper division of the Claggett at the mouth of Judith River, contain carbonaceous beds and fresh or brackish water shells and are, therefore, of fresh or brackish water origin. Inasmuch as the occurrence of marine fossils in the upper division of the Claggett seems to be a local phenomenon, inasmuch as these marine fossils are not limited strictly to the Claggett as now defined but in some places extend up into the overlying Judith River formation, and inasmuch as the most striking lithologic change in the beds is at the base of the upper division of the Claggett, it seems to the writer that this is the most logical horizon to designate as the boundary between the Claggett and Judith River formations. It also constitutes a horizon that may be readily recognized in the field because of the striking difference between the dark fossiliferous marine shale and the overlying lighter-colored sandstone. It is true, however, that these marine strata were excluded from the Judith River formation in all the early descriptions of the type area, and this fact doubtless influenced Stanton and Hatcher in fixing the upper boundary of the Claggett formation when they described it in the same area.

Prior to the work of Stanton and Hatcher the upper division of the Claggett was called Fox Hills, and that assignment has recently been reiterated by Peale. ${ }^{1}$ This correlation is based on the fact that many of the fossils occurring in the upper division of the Claggett at the mouth of Judith River are identical with those that occur elsewhere in the typical Fox Hills. The relations of this fauna are discussed more fully in the paleontologic part of this paper (pp. 114-115), and it will suffice here to point out that this so-called Fox Hills sandstone has been traced by means of its fauna from Missouri River southward as far as the North Moccasin Mountains and has been recognized by its color and lithology at other places as far south as Flat Willow Creek and that it is positively known to be overlain at these places by the Judith River formation and a marine shale (the Bearpaw) which has a Pierre fauna. The sandstone therefore does not occupy the stratigraphic position of the Fox Hills sandstone at the type locality.

\section{JUDITH RIVER FORMATION.}

The Judith River formation is chiefly of fresh or brackish water origin and lies between two marine shales. The formation was named by Hayden in $1871,{ }^{2}$ but at that time its stratigraphic position was not understood. In 1903 Stanton and Hatcher ${ }^{3}$ determined that the formation is a member of the Montana group and is the time equivalent of a part of the Pierre shale.

Character and thickness. - The Judith River formation consists of alternating beds of lightcolored sandstone and clay, in which occur thin beds of carbonaceous shale. In the northern

1 Peale, A. C., On the stratigraphic position and age of the Judith River formation: Jour. Geology, vol. 20, pp. 755-756, 1912.

${ }^{2}$ Hayden, F. V., Geology of the Missouri Valley: U. S. Geol. Survey Terr. [Fourth Ann.] Prel. Rept., p. 97, 1871.

3 Op. cit., p. 257. 
part of the area the formation contains some coal but is not known to be coal bearing east of Armells Creek. It yields fresh and brackish water invertebrates and locally some of marine origin. At many places there is near the top of the formation a bed ranging from less than 1 foot to several feet in thickness that is made up almost wholly of shells of Ostrea subtrigonalis and is therefore called the Ostrea marl or breccia. The formation also contains bones of vertebrates, much silicified wood, and stems and fragments of plants, though well-preserved leaves are exceedingly rare.

The thickness of the formation on Willow Creek in the southern part of the area, as determined by stadia measurements, is 250 to 275 feet. It seems gradually to thicken northward, and in the northern part of the area it is about 500 feet thick.

Distribution and topographic expression.-The surface distribution of the Judith River formation from the south side of the field to T. $20 \mathrm{~N}$. is shown on the accompanying map (Pl. X). North of T. 20 N. its upper boundary was not mapped. The variations in the width of the outcrop of the formation coincide in a general way with those of the underlying Claggett formation.

Where the beds are nearly flat-lying, as in the areas south of Flat Willow Creek and northwest of Roy, the Judith River weathers into badland forms, but where the beds dip steeply the formation gives rise to narrow ridges with sandstone ribs along their crests, very similar to the ridges formed by the Eagle sandstone. The Judith River is well exposed and its outcrop is easily traced because of its position between the shaly Claggett and the Bearpaw shale, both of which occupy low ground. The formation was traced from the southern border of the field northward nearly to Boxelder Creek, where it passes beyond the eastern limit of the area mapped. It reenters the area in T. 15 N., R. 29 E. There is no doubt that if followed farther east the formation could be traced continuously around this gap ${ }^{1}$ and that all the formations exposed south of Boxelder Creek could be connected directly with those on the north border of the field. The sequence, character, and fauna of the formations are identical in these two areas. From T. 15 N., R. 29 E., the Judith River formation was traced continuously to the mouth of Judith River and was there found to be identical with the Judith River formation of Hayden, this locality being in the western part of his original area. As far west as Roy the formation, because of its highly inclined attitude, makes a hogback ridge and may be traced almost as readily as a turnpike. West of Roy it is well exposed along the main drainage lines, such as Boxelder Creek, Armells Creek, and Dog Creek, though it is commonly not well exposed on the divides. West of Dog Creek the exposures are continuous along the east side of the valley of Judith River and its tributaries from the North Moccasin Mountains north to Judith. The tracing of the formation across the field is therefore rendered very certain.

As the possibility of mistaken identification of formations in the faulted area north of Fullerton may be urged and doubt therefore cast on the above statements, it may be well to point out again that the correlations in this part of the field do not rest on the tracing of the Judith River formation alone, but that the underlying Claggett formation, composed of two distinct members (the Pierre and Fox Hills of Peale and many of the earlier geologists), each containing a characteristic fauna, can be traced with equal certainty. (See quotation from Peale, p. 111.) On page 104 it is stated that the maximum displacement due to the faults north of Fullerton is probably about 650 feet, and that therefore the key rocks - the two members of the Claggett formation-are in no place lost to sight. In view of these conditions it seems to the writer that no valid objection can be raised as to the correlation of the formations across this faulted zone.

Relation to other formations. - The relation of the Judith River to the Claggett is considered on pages 99-100. The formation lies beneath the Bearpaw shale, with which it shows conformable relations throughout this field. The evidences of the stratigraphic position and age of the Judith River formation are considered more in detail in another part of this paper.

1 Since this paper was prepared the writer has traced the Judith River formation around this gap and has thus positively proved its continuity throughout this field. 


\section{BEARPAW SHALE.}

The Bearpaw shale overlies the Judith River formation and is equivalent to the upper part of the Pierre shale. The formation was named and its stratigraphic relations were determined by Stanton and Hatcher ${ }^{1}$ in 1903.

Character and thickness.-The Bearpaw is a dark marine shale of the same lithologic character as the Claggett of this field and the Pierre shale of other localities. It contains numerous calcareous concretions from which Baculites ovatus, Baculites compressus, Scaphites nodosus, Leda evansi, and other fossils characteristic of the Pierre are obtained. The formation has a thickness of 1,150 feet south of Willow Creek, and this thickness seems to be fairly constant throughout the field so far as the entire formation was studied.

Distribution and topographic expression.-The Bearpaw has a similar distribution to that of the Judith River. The upper boundary of the formation was mapped as far west as R. 24 E., and the lower boundary to about the center of T. 20 N., R. 19 E.; at that point the outcrop bears off to the east, and a few miles beyond it becomes involved in extensive faults.

The Bearpaw weathers easily and its outcrop generally occupies a depression between the Judith River and Lance formations, but this feature becomes less distinctive as the width of the outcrop increases. The formation is well exposed throughout most of the area in which it was mapped, but, like the Judith River, the Bearpaw passes beyond the eastern margin of the field and therefore was not traced continuously throughout the area.

Relation to other formations. - The Bearpaw is similar in lithology and paleontology to the Pierre shale of other localities and to the shale of the Claggett formation in this field. Because of this similarity the Bearpaw and Claggett were confused by the early geologists who visited this region and both were called Pierre shale. The following differences have been observed between the Bearpaw and the Claggett: (1) The Bearpaw is much thicker, as shown by the table on page 96. (2) The Bearpaw is more fossiliferous and contains a more diversified fauna. (3) In many places in this field a bed consisting almost wholly of brackish-water shells, largely Ostrea subtrigonalis, lies immediately beneath the Bearpaw. In this field no shells of this kind are found immediately beneath the Claggett.

The similarity in the fauna of the Bearpaw and the shale of the Claggett is shown by 'the following list of fossils:

TABLE 1.-Invertebrate fossils from the shale of the Claggett formation and the Bearpaw shale.

NoтE.-Species marked "1" were collected by Stanton and Hatcher. Species marked "2" are those collected by the writer and his assistants in 1912 which are not included in Stanton's list.

\begin{tabular}{|c|c|c|c|c|c|}
\hline & Claggett. & Bearpaw. & & Claggett. & Bearpaw. \\
\hline 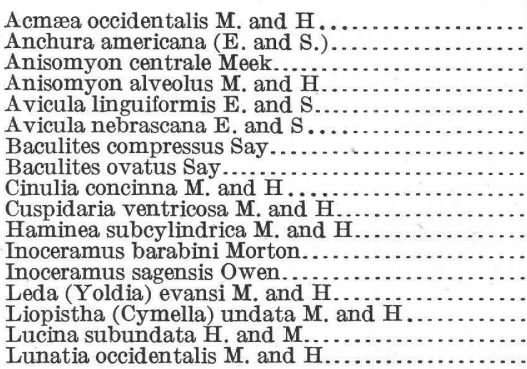 & 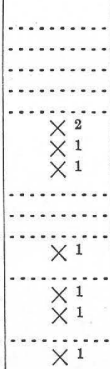 & $\begin{array}{l}\times 1 \\
\times 1 \\
\times 1 \\
\times 1 \\
\times 1 \\
\times 1 \\
\times 1 \\
\times 1 \\
\times 1 \\
\times 1 \\
\times 1 \\
\times 1 \\
\times 1 \\
\times 12 \\
\times 1 \\
\times 1 \\
\times 1 \\
\times 1 \\
\times 1\end{array}$ & 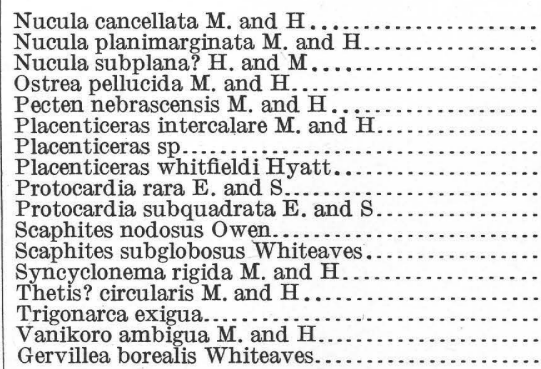 & 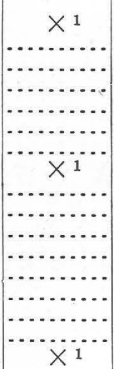 & $\begin{array}{c}\times 1 \\
\times 1 \\
\times \\
\times 1 \\
\times 1 \\
\times 1 \\
\times 1 \\
\times \times^{1} \\
\times 1 \\
\times{ }^{1} \\
\times 1 \\
\times 1 \\
\times \\
\times 1 \\
\times 1 \\
\times 1 \\
\times 1\end{array}$ \\
\hline
\end{tabular}

An inspection of this table shows that all the species found in the shale of the Claggett formation are also represented in the Bearpaw, but that the fauna of the latter is more varied than that of the former. This coincides with the field observations that fossils are more numerous in the Bearpaw than in the Claggett. 
TERTIARY (?) SYSTEM.

LANCE FORMATION.

No detailed study was made of the Lance formation, though its lower boundary was traced nearly halfway across the area mapped. The following statement concerning it is taken from the report by C. T. Lupton on the eastern part of the Bull Mountain coal field, ${ }^{1}$ which adjoins this area on the south:

It consists of 700 to 800 feet of yellowish-gray sandstone, clay of various colors, and grayish sandy shale. Sandy material predominates. The lower part is noticeably micaceous; the upper part contains thin beds of coal. Where the formation dips steeply it makes hogbacks with narrow valleys between, and where it is nearly level it makes a series of scarps. Few fossils have been found in this formation.

Two detailed sections were measured south of Willow Creek for the purpose of showing the transition from the Bearpaw to the Lance. One of these is given below.

Section of transitional beds between typical Bearpaw shale and typical Lance formation, T. 29 N., R. 9 E., Montana.

Typical Lance.

Sandstone, buff to rusty, slightly cross-bedded........................ 8

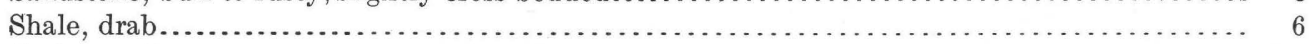

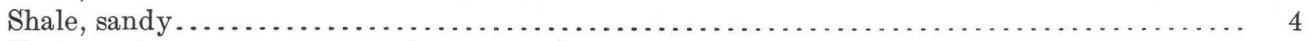

Shale, carbonaceous; contains fragments of stems of plants $\ldots \ldots \ldots \ldots \ldots \ldots \ldots \ldots \ldots \ldots \ldots \ldots$

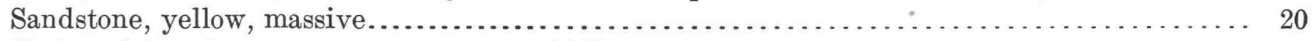

Shale, with carbonaceous member near middle................................. 10

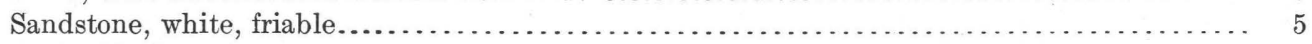

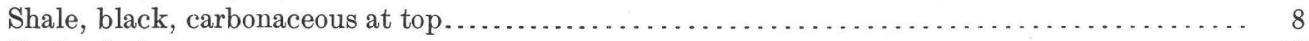

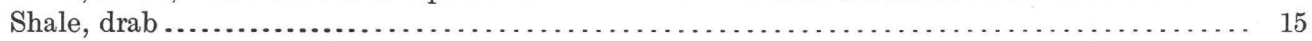

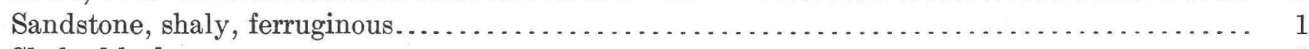

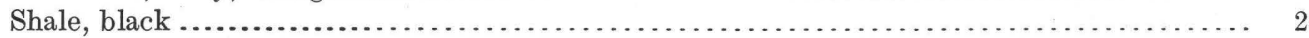

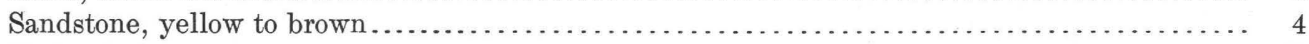

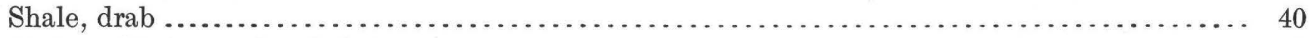

Shale, with intercalated shaly sandstone members................................. 8

Shale, typical Bearpaw, drab, concretionary, containing Baculites and other forms.

\section{STRUCTURE.}

\section{FOLDS AND DOMES.}

The dominant structure in the eastern part of the area is a broad symmetrical fold-the Big Snowy anticline - on which are superimposed several smaller folds, thus producing the type of fold known as an anticlinorium. The axis of the Big Snowy anticline trends northwest and pitches to the southeast. Out on the plains the strata on opposite limbs of this fold dip at angles ranging from $20^{\circ}$ to $70^{\circ}$. Toward the mountains the dips decrease in amount and from Black Butte westward along the north base of the Judith and Moccasin mountains they do not exceed $45^{\circ}$ and the anticline loses its distinctive character.

The minor folds, consisting of the Devils Basin, Flat Willow, and Cat Creek anticlines with intervening synclines, are also open symmetrical folds whose axes pitch to the southeast and trend roughly northwest but are somewhat sinuous in outline. The dips on opposite limbs of these folds as a rule range from $2^{\circ}$ to $6^{\circ}$ and rarely exceed $10^{\circ}$.

A dome structure has been produced by the laccoliths which have given rise to Black Butte and the North Moccasin Mountains. So far as traced, the beds dip steeply away from these uplifts, except at the southeast side of Black Butte, where they dip steeply toward the butte, probably as the result of faulting.

Out on the plains north of the Judith and North Moccasin mountains the strata dip at a low angle to the north or northeast. 
FAULTS.

In this region faults are important structural features only in the area north of T. $20 \mathrm{~N}$. Two minor faults on the north side of the Judith Mountains are shown on the map (Pl. X), and, as already pointed out, there is probably a small fault at the southeast side of Black Butte. Between Fullerton and Missouri River three prominent faults and some minor ones, striking a little west of north, cross the valley of Judith River. These faults all appear to be of the normal type. At the first and second faults north of Fullerton the beds dip steeply to the north near the fault plane but are nearly flat a short distance away. At the fault nearest Missouri River they dip to the south, and there is evidence of some minor faults, the details of which were not worked out. The northernmost fault exhibits the maximum throw observed, and at that place the white massive Virgelle sandstone member at the base of the Eagle is brought into juxtaposition with the sandstone beds constituting the upper part of the Claggett formation. If a thickness of 150 feet is allowed for that part of the Eagle above the white massive Virgelle sandstone and 500 feet for the lower or shaly portion of the Claggett, the throw of the fault would be about 650 feet.

Fault lines were seen also on the east side of Dog Creek, in T. 21 N., R. 19 E., where the structure seems more complicated than on Judith River. The maximum disturbance is probably shown along Missouri River between Armells Creek and Dog Creek. Speaking of this area Hayden ${ }^{1}$ says:

It presents perhaps the most rugged scenery on the Missouri River, the denudation and erosion having been much greater than at the badlands of White River. But the most remarkable feature of this basin is the wonderful disturbance of the strata. So much are the beds disturbed and blended together by forces acting from beneath that it seems almost hopeless to obtain a section showing with perfect accuracy the order of superposition of the different strata.

STRATIGRAPHIC POSITION AND AGE OF THE JUDITH RIVER FORMATION.

SCOPE OF DISCUSSION.

In the foregoing pages the discussion has been confined chiefly to the stratigraphy of the formations in the area represented by the shaded portion of the accompanying map ( $\mathrm{Pl}$. $\mathrm{X}$ ). In presenting the evidence now at hand bearing on the position and age of the Judith River formation it is necessary to give a brief review of previous opinions as to the age of these beds and the stratigraphic succession in the type area of the Judith River formation, to correlate the formations in the type area with those in the area herein considered, and to present the paleontologic evidence as to the age of the Judith River and associated formations.

HISTORICAL SUMMARY.

The literature bearing on the stratigraphic position and age of the Judith River formation has been fully and carefully reviewed by Stanton and Hatcher. ${ }^{2}$ For that reason only a brief synopsis, sufficient to give the reader an understanding of the various opinions held, is presented here.

NAME.

The name Judith River group was first given to this formation by Hayden ${ }^{3}$ in 1871 . After discussing the Fort Union "group," he says:

There is another basin near the sources of the Missouri River which has already yielded many fossils of great interest but which seems to be isolated from the others. This is what I have called the Judith Basin, and inasmuch as it seems to be one of the ancient lake deposits, and characterized by a peculiar group of organic remains, I will designate the strata as the Judith group. The sediments do not differ materially from those of the Fort Union group and they contain impure beds of lignite, fresh-water Mollusca, and a few leaves of deciduous trees. But the most remarkable feature of

${ }^{1}$ Hayden, F. V., Notes explanatory of a map and section illustrating the geological structure of the country bordering on the Missouri River from the mouth of the Platte River to Fort Benton: Acad. Nat. Sci. Philadelphia Proc., vol. 9, pp, 115-117, 1857.

2 Stanton, T. W., and Hatcher, J. B., op. cit., pp. 14-31.

3 Hayden, F. V., Geology of the Missouri Valley: U. S. Geol. Survey Terr. [Fourth Ann.] Prel. Rept., p. $97,1871$. 


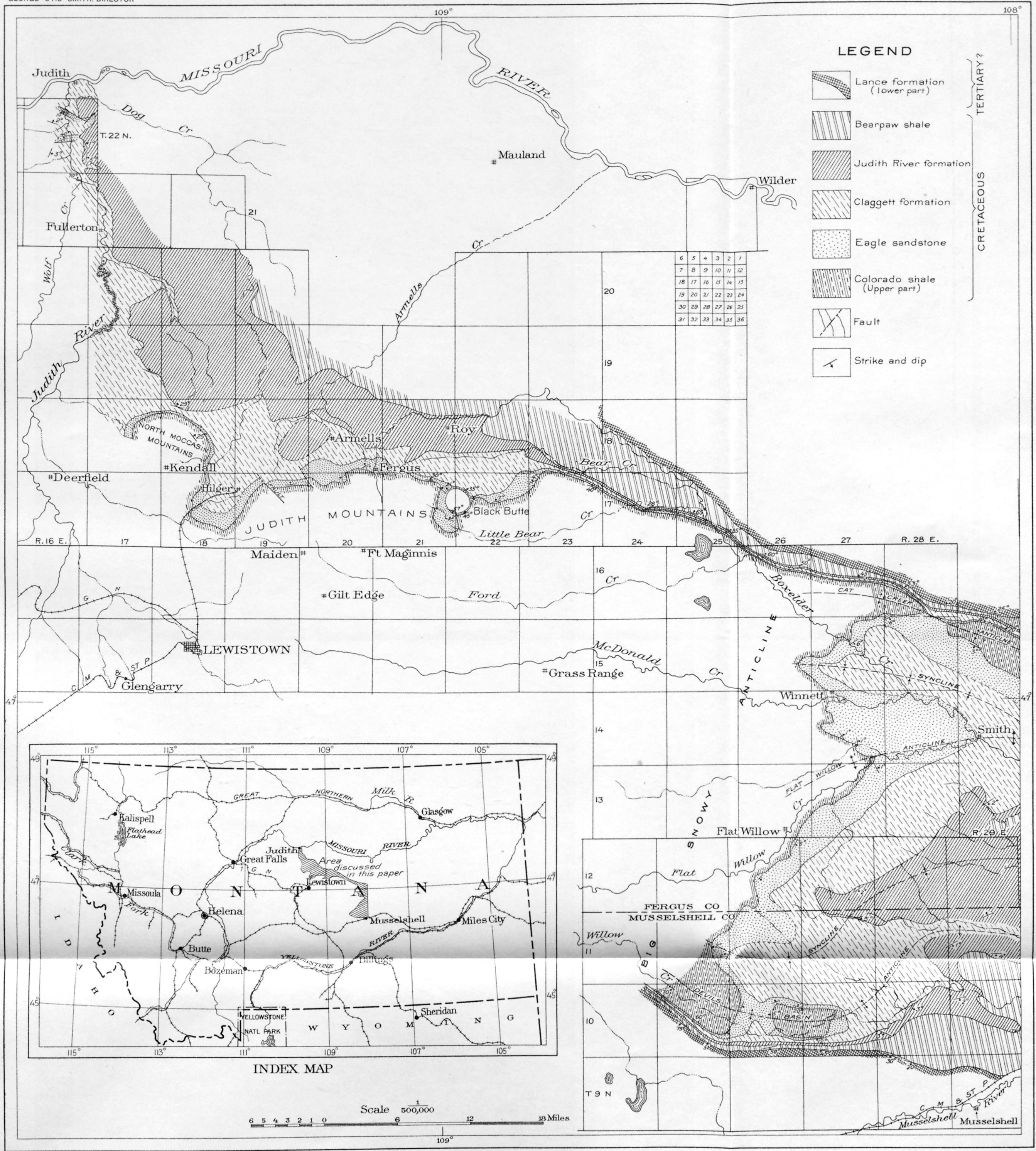

GEOLOGIC MAP OF AREA EXAMINED, BETWEEN MUSSELSHELL AND JUDITH, MONTANA By C. F. Bowen 
this group is the number and variety of the curious reptilian remains, of which we have only yet caught a glimpse. There is probably no portion of the West that furnishes such a harvest of fossil remains and instructive geological facts as the country bordering the Missouri River from the mouth of the Yellowstone to the foot of the mountains above the Great Falls of the Missouri; and as this country is reserved for examination the coming season I will leave the obscurity which now invests it to be cleared in the next annual report.

Prior to that time the term Judith River beds had been used in a general way ${ }^{1}$ to include all the formations exposed near the mouth of Judith River. Since the strata were named by Hayden the terms Judith River beds and Judith River formation have been used as synonymous with Hayden's term Judith River group, which has finally been supplanted by the term Judith River formation.

\section{ORIGINAL AREA AND TYPE LOCALITY.}

No exact locality was designated by Hayden as representing the type of this formation. It is evident, however, as the following quotation ${ }^{2}$ will show, that the area in which his Judith River group occurs lies along Missouri River between Judith River on the west and the mouth of Musselshell River on the east.

Near the mouth of the Judith River, not far from the sources of the Missouri, in latitude $47^{\circ} 30^{\prime}$, longitude $109^{\circ} 30^{\prime}$, is a wild, desolate, and rugged region, which I have called the "Badlands of the Judith," in contradistinction to those of White River. ***

The area occupied by this peculiar basin I could not determine with precision, but have estimated it at about 40 miles from east to west and from 15 to 30 from north to south, and it is separated into two nearly equal portions by the Missouri. The Judith River rises in the Judith Mountains, pursues a course nearly due north, for the most part through Cretaceous strata, and empties into the Missouri in latitude $48^{\circ}$, longitude $106^{\circ}$ [about $110^{\circ}$ ]. The Judith River forms the north [western] boundary of this basin. The Muscle Shell River also rises near the Judith Mountains but takes a course a little east of north, flows through Cretaceous formation No. 4, and empties into the Missouri near latitude $47^{\circ} 30^{\prime}$ and longitude $108^{\circ}$. That portion of the "Badlands" which is formed of the estuary deposit under consideration lies between these two streams.

\section{PREVIOUS OPINIONS OF STRATIGRAPHIC POSITION AND AGE.}

In $1856^{\circ}$ Meek and Hayden ${ }^{3}$ correlated the marine formation immediately underlying the Judith River formation at the mouth of Judith River with the base of the Cretaceous. This correlation was based on the lithologic similarity of this formation to formation No. 1 (Dakota) and on the fossil evidence, especially that of the vertebrates, as determined by Leidy. In another paper ${ }^{4}$ in the same volume Meek and Hayden suggest that this marine sandstone probably represents the older members of the Cretaceous but that it may be as old as Jurassic. In 1857 Hayden ${ }^{5}$ described and mapped the badlands of Judith River as occupying a Tertiary basin. Later in the same year Meek and Hayden, ${ }^{6}$ on the basis of the invertebrate fauna, again assigned the Judith River formation to the Tertiary but said that the saurian and fish remains ally it to the Wealden. In 1858 Hayden, ${ }^{7}$ after studying a fresh-water fauna at the base of the Cretaceous in the Black Hills region, assigned the Judith River to the Cretaceous, thus reversing his former opinion, and said that it may be the American representative of the Wealden. After a reexamination of the invertebrates of the Judith River formation and a comparison of these fossils with the forms from the Black Hills, Meek and Hayden referred the

1 Meek, F. B., and Hayden, F. V., Descriptions of new fossil species of Mollusca collected by Dr. F. V. Hayden in Nebraska Territory, together with a complete catalogue of all remains of Invertebrata hitherto described and identified from the Cretaceous and Tertiary formations of that region: Acad. Nat. Sci. Philadelphia Proc., vol. 8, pp. 265-286, 1856.

2 Hayden, F. V., Geological sketch of the estuary and fresh-water deposit of the badlands of the Judith, with some remarks upon the surrounding formations: Am. Philos. Soc. Trans., new ser., vol. 11, p. 123, 1860.

${ }^{3}$ Meek, F. B., and Hayden, F. V., Some general remarks on the geology of the country about the sources of the Missouri River: Acad. Nat. Sci. Philadelphia Proc., vol. 8, p. 114, 1856.

${ }^{4}$ Acad. Nat. Sci. Philadelphia Proc., vol. 8, p. 267, 1856.

5 Hayden, F. V., Notes explanatory of a map and section illustrating the geological structure of the country bordering on the Missouri River from the mouth of the Platte River to Fort Benton: Acad. Nat. Sci. Philadelphia Proc., vol. 9, pp. 109-116, map, 1857.

${ }^{6} \mathrm{Meek}, \mathrm{F}$. B., and Hayden, F. V., Descriptions of new species and genera of fossils collected by Dr. F. V. Hayden in Nebraska Territory, under the direction of Lieut. G. K. Warren, U. S. Topographical Engineer: Idem, pp. 117-148.

${ }^{7}$ Hayden, F. V., Explanations of a second edition of a geological map of Nebraska and Kansas: Acad. Nat. Sci. Philadelphia Proc., vol. 10, pp. 139-158, map, 1858. 
Judith River back to the Tertiary. Speaking of the fresh-water Jurassic of the Black Hills, they said: ${ }^{1}$

At the time we published these facts [concerning the fresh-water Jurassic of the Black Hills] we were led by the discovery here of fresh-water shells, in such a position, to think that some estuary deposits of doubtful age, near the mouth of Judith River, on the Missouri, from which Dr. Leidy had described some saurian remains resembling Wéalden types, might be older than the Tertiary. Later examinations, however, have demonstrated that the Judith beds contain an entirely different group of fossils from those found in the rock under consideration, and that they are really of Tertiary age and hold a position at the base of the great lignite series of the Northwest.

In another paper published in the same year, ${ }^{2}$ after classifying the Tertiary basins of the Northwest, Hayden referred the Judith River formation to the Tertiary, as follows:

The estuary deposits, of which the Judith basin may be regarded as the type, are quite remarkable and of a most interesting character. Opinions of a somewhat conflicting nature have been entertained in regard to them, owing to the peculiar character of the organic remains, but recent observations have convinced me that they are all of Tertiary age, and that they are quite widely distributed throughout the far West.

In 1875 both Meek ${ }^{3}$ and Hayden ${ }^{4}$ announced independently that the marine sandstone immediately underlying the Judith River formation near the mouth of Judith River had been definitely çorrelated with the Fox Hills, but in 1876, in his last writings on the subject, Meek ${ }^{5}$ referred the Judith River to the Cretaceous, as follows:

We have long regarded the Judith River beds as forming a distinct group older than the Fort Union deposits. * * * That these older beds (the Judith River brackish and fresh water deposits and their equivalents elsewhere) are Cretaceous is certainly highly probable, as has been suggested by the author on former occasions; yet this can scarcely be properly regarded as an established fact.

In 1856 Leidy ${ }^{6}$ published his first determinations of the vertebrate collection made by Hayden in the Judith River basin, and allied the vertebrates of the Judith River formation with those of the Wealden of Europe.

In 1860 Leidy ${ }^{7}$ made the following statement:

The association of the remains of Trachodon, Deinodon, Crocodilus, and Lepidotus, corresponding with the association of the remains of the closely allied Iguanodon, Megalosaurus, Crocodilus, and Lepidotus of the Wealden formation of England, led the author to suspect the Judith River formation was of cotemporary age, though he was fully aware of the fact that totally dissimilar animals have occupied different portions of the earth at the same period.

In $1871 \mathrm{Cope}^{8}$ referred the Judith River fossils to the Upper Jurassic. In 1873 he placed the Judith River formation in the Cretaceous on the basis of the fossil remains, ${ }^{9}$ and in the following year (1874) he assigned it to the top of the Cretaceous. ${ }^{10}$ In 1877 he assigned the black shale "No. 4" (now called Claggett) to the Pierre, and the overlying marine sandstone, which marks the transition to the Judith River, to the Fox Hills sandstone." He also said:12 "The positive age of the Judith River fauna is Cretaceous, with some Tertiary affinities."

1 Meek, F. B., and Hayden, F. V., Descriptions of new lower Silurian (Primordial), Jurassic, Cretaceous, and Tertiary fossils collected in Nebraska, by the exploring expedition under the command of Lieut. G. K. Warren, with some remarks on the rocks from which they were obtained: Acad. Nat. Sci. Philadelphia Proc., vol. 13, pp. 415-447, 1861.

2 Hayden, F. V., Sketch of the geology of the country about the headwaters of the Missouri and Yellowstone rivers: Am. Jour. Sci., 2d ser., vol. 31, pp. 229-24.5, 1861

${ }^{3}$ Meek, F. B., Note on some fossils from near the eastern base of the Rocky Mountains, west of Greeley and Evans, Colo., and othersfrom about 200 miles farther eastward, with descriptions of a few new species: U. S. Geol. and Geog. Survey Terr. Bull., vol. 1, 2d ser., p. 39, 1875.

4 Hayden, F. V., Notes on the lignitic group of eastern Colorado and portions of Wyoming: Idem, p. $403,1876$.

5 Meek, F. B., A report on the invertebrate Cretaceous and Tertiary fossils of the upper Missouri country: U. S. Geol. Survey Terr. Repts., vol. 9 , pp. xlvii, 1,1876 .

${ }^{6}$ Leidy, Joseph, Notices of the remains of extinct reptiles and fishes discovered by Dr. F. V. Hayden in the badlands of the Judith River, Nebraska [Montana] Territory: Acad. Nat. Sci. Philadelphia Proc., vol. 8, pp. 72-73, 1856.

${ }^{7}$ Leidy, Joseph, Extinct Vertebrata from the Judith River and Great Lignite formations of Nebraska: Am. Philos. Soc. Trans., new ser., vol. 11, pp. 139-140, 1860 .

${ }^{8}$ Cope, E. D., Extinct Batrachia, Reptilia, and Aves of North America: Am. Philos. Soc. Trans., new ser., vol. 14, pp. 1-252, 1871.

9 Cope, E. D., Report on the vertebrate paleontology of Colorado: U. S. Geol, and Geog. Survey Terr. [Seventh] Ann. Rept. [for 1873], p. 434, 1874.

${ }^{10}$ Cope, E. D., Review of the Vertebrata of the Cretaceous period found west of the Mississippi River: U. S. Geol. and Geog. Survey Terr. Bull., vol. 1, 1st ser., No. 2 , pp. 6-8, 1874 .

11 Cope, E. D., Report on the geology of the region of the Judith River, Montana, and on vertebrate fossils obtained on or near the Missouri River: U. S. Geol. and Geog. Survey Terr. Bull., vol. 3, pp. 565-598, plates 30-34, 1877.

12 Idem. p. 576 . 
While this work was being carried on in the United States, G. M. Dawson was engaged in the study of the Belly River formation of Canada, which he correlated with the Judith River formation, as follows: ${ }^{1}$

Briefly stated, it would appear from the investigations now reported on that considerable areas of the beds which in 1874 I called "Lignite Tertiary"-here and in previous announcements designated as Belly River series-must be relegated to a position below the Pierre shales, or at least to one below an upper portion of these shales. The beds thus separated as the Belly River series were, in 1875, by me correlated with the Judith River series of the Missouri. Additional and extensive collections of fossils since obtained and now being worked out confirm and strengthen this correlation and lead to the presumption that the so-called Judith River series must also occupy a position well down in the undoubted Cretaceous. It may be added that this was the view originally held by Messrs. Meek and Hayden and supported, it would appear, not alone on the supposed analogies of the vertebrate remains examined for them by Prof. Leidy, but also on stratigraphic evidence-evidence which perfectly agrees with the impressions resulting from such cursory examination as I was able to make of the Missouri sections from the deck of a steamer while ascending the river in 1881.

In 1885 the invertebrate fossils of the Belly River were described by J. F. Whiteaves, ${ }^{2}$ who commented on them as follows:

Judging by their respective invertebrate faunas, it would seem impracticable to separate the "Belly River series" from the Laramie, and more especially from the "Judith River group," on purely paleontological evidence.

The invertebrate fauna of the "Belly River series" seems to be essentially the same as that of the "Laramie" of the United States and Canada, unless more than one formation has been confounded under the latter name, and * * * it is at present scarcely possible to separate the "lower dark shales" of Dr. Dawson's Bow and Belly River report from the "Fort Pierre and Fox Hills" groups on purely paleontological grounds.

\section{In 1902 Osborn ${ }^{3}$ made the following statements:}

The Survey had established beyond question, geologically, that the Belly River series is mid-Cretaceous, that it underlies the Montana or Fort Pierre-Fox Hills group and overlies the Fort Benton and Dakota groups. * * * It soon appeared to the writer in the study of the fine collection made by Mr. Lambe that the Belly River vertebrates of the Northwest Territory were of decidedly different and apparently of older type than those from the Laramie beds of Converse County, Wyo., described by Marsh, and were rather to be compared with those described by Leidy, Cope, and Marsh from Montana, chiefly from the Judith River beds, a region by no means distant geographically.

Thus the correlation between the Belly River and Judith River series, proposed by the late Director, Dr. G. M. Dawson, in 1875, at first glance appeared to be confirmed faunistically; but this correlation is not supported by the geological records, which all place the Judith River beds proper above the Fox Hills and Fort Pierre. * * *.

There is thus very little in common between the Belly River fauna and the Laramie fauna of Wyoming and Colorado so far as described, except the dinosaur Ornithomimus and the very persistent chelonian Baena. Most of the dinosaurs will probably be found to be separated generically.

On the other hand, so far as known, the Montana fauna has much in common with the Belly River, especially the Testudinata, Iguanodontia, and Ceratopsia.

In 1903 Stanton and Hatcher ${ }^{4}$ studied both the Judith River and Belly River formations and defined the stratigraphic position of the Judith River as follows:

Our field studies in the original Judith River area have established the stratigraphic succession of the Upper Cretaceous section and show that the Judith River beds lie beneath several hundred feet of marine Cretaceous shales with a characteristic invertebrate fauna, and that they rest upon another marine formation which also bears an abundant fauna. The overlying formation we have called the Bearpaw shales, because it is well exposed in the area south, east, and north of the Bearpaw Mountains. The name Claggett formation has been given to the underlying beds because they are well developed around the site of old Fort Claggett, near the mouth of Judith River. Wherever the exposures in this region show lower beds the lignite and conspicuous sandstone ledges of the Eagle formation are seen, and still lower the dark Benton shales with a characteristic fauna are revealed. The Judith River formation itself has yielded a fauna of both vertebrates and invertebrates, most of which are peculiar to it. Its lithologic features also are different from those of any other formation in the section and make it easily recognizable.

Beyond the typical area we found on Milk River, in the neighborhood of Havre, a similar succession of formations from the Claggett to the Bearpaw, inclusive. The formation occupying the position of the Judith River beds here has the same lithologic and paleontologic characteristics as in the original area, with which it probably has direct connections around the east end of the Bearpaw Mountains. It is therefore unhesitatingly identified with the Judith

1 Dawson, G. M., Report on the region in the vicinity of the Bow and Belly rivers, Northwest Territory: Geol. Survey Canada Rept. Progress 1882-1884, p. 119c, maps, 1885.

2 Contr. Canadian Paleontology, vol. 1, pt. 1, pp. 55, 89, 1885.

3 Osborn, H. F., Distinctive characters of the mid-Cretaceous fauna: Contr. Canadian Paleontology, vol. 3, pt. 2, pp. 7-21, 1902.

4 Stanton, T. W., and Hatcher, J. B.; Geology and paleontology of the Judith River beds: U. S. Geol. Survey Bull. 257 , pp. $62,66,1905$. $37183^{\circ}-15-8$ 
River beds. From Havre this formation was traced by means of practically continuous exposures and without essential change of lithologic and paleontologic characters into an area of Belly River beds mapped by Dawson. Here again the underlying Claggett formation was recognized by its fossils and lithologic features, and above the Judith River (Belly River) beds the Pierre shales of the Canadian geologists are clearly identical with the Bearpaw shales of our Montana section.

In other areas studied by us in Montana the same succession of formations was observed. Two horizons in this region are especially well characterized by marine invertebrates-one in the upper part of the Benton shales and the other in the Bearpaw shales. Wherever these were both present in one section the succession and recognition of the intervening formations were unmistakable. * * *

Our principal conclusions from the season's work may be summarized as follows:

1. The Judith River beds are distinctly older than the Laramie, being separated from the latter by at least several hundred feet of marine shales, identical in their faunal and lithologic features with the Pierre, to which we have given the local name Bearpaw shales, from the Bearpaw Mountains, about which they are well exposed.

2. The Belly River beds of Canada are identical with the Judith River beds of Montana. The name Judith River beds, having priority, should be the accepted name for this formation, and the terms Belly River and Fish Creek beds should be dropped.

3. The marine sandstones and shales immediately underlying the Judith River beds do not represent either the Benton, as some Canadian geologists have supposed, or the Fox Hills and upper Pierre, as most geologists of the United States who have examined them have believed, but they constitute a distinct horizon within the Montana group which we have called the Claggett formation, from old Fort Claggett, at the mouth of Judith River, near which they are well developed.

4. The Eagle formation, from its stratigraphic position and faunal relations, marks the base of the Montana group in this region.

5. The Bearpaw shales, the Judith River beds, the Claggett, and the Eagle formations all belong to the Montana group and together probably form the equivalent of the Pierre as that term is generally understood, though the possibility is recognized that in the typical area the Pierre may have more restricted limits.

6. Faunas similar to that of the Fox Hills sandstone have a great vertical range and are likely to be found at any horizon within the Montana group where a littoral or shallow-water facies is developed. The use of the term Fox Hills as a formation or horizon name outside of the original area in South Dakota is therefore of doubtful propriety, as experience has shown.

In 1911 A. C. Peale, who had done work in the Judith River region in connection with the Hayden Survey, revisited that area and spent a month in the field in a special study of the Judith River formation. As a result of this study Peale in 1912 published a paper ${ }^{1}$ in which he contended for the Tertiary age of the formation, thus reverting to the opinions which had been held by some geologists before the work of Stanton and Hatcher. His conclusions are given in the following quotation:

Our first conclusion, therefore, is that the Judith River beds and the Belly River series, although both of freshwater origin and lithologically very similar, are entirely distinct from each other, occupying stratigraphical positions separated by 1,000 feet or more of marine sandstones and shales. * * * Our second conclusion is that the Fox Hills formation, with its characteristic fauna and flora, immediately and unconformably underlies the Judith River beds and that it rests conformably upon exposures of characteristic Pierre shales throughout the Judith Basin. * * * We have no hesitation in stating the third conclusion, viz, that the Judith River formation is the representative if not the exact equivalent of the whole or some, perhaps lower, portion of the Lance formation, and that the latter name should be replaced on the ground of priority of use by the name Judith River formation. * * * We are fully warranted in concluding, as pointed out by Dawson long ago, that the Belly River series is of Niobrara age. * * * Apparently the entire series from the base of the Eagle sandstone to the base of the Pierre shales is a unit representing the Canadian Belly River formation.

The foregoing sketch briefly summarizes the views that have been held regarding the age and position of the Judith River formation. A review of the evidence shows that on the basis of its vertebrate remains the Judith River formation has generally been assigned to the Cretaceous, although differences of opinion have been expressed as to its exact position in the Cretaceous section. Before the characteristics of the Upper Cretaceous dinosaurs were well known Leidy, Meek, Hayden, and Cope thought that the remains from the Judith River formation were closely allied to the Wealden (Lower Cretaceous) of Europe, and hence the formation was considered to be of Lower Cretaceous age. But as the Upper Cretaceous dinosaurs came to be better known it was generally recognized that the remains from the Judith River formation have their closest allies in the Upper Cretaceous. From that time on practically all vertebrate

1 Peale, A. C., On the stratigraphic position and age of the Judith River formation: Jour. Geology, vol. 20, pp. 530-549,640-652,738-757, 1912. 
paleontologists have regarded the Judith River formation to be of Upper Cretaceous age. On the other hand, the invertebrate evidence, though somewhat conflicting in its nature, has been regarded by the earlier writers as showing a closer affinity with the Tertiary than with the Cretaceous. Finally, the stratigraphic evidence has been interpreted, except by Dawson and by Stanton and Hatcher, as indicating that the Judith River formation is younger than the Fox Hills, and therefore at the top of the Cretaceous or the base of the Tertiary.

\section{REVIEW OF THE STRATIGRAPHY IN THE TYPE AREA OF THE JUDITH RIVER FORMATION.}

Hayden's best account of the stratigraphy in the type area of the Judith River formation, from which the following extracts are taken, was published in $1860 .{ }^{1}$

So intimately do the estuary beds at the mouth of the Judith seem to be connected with Gretaceous formation No. 1 that it will be important to present such facts as are known in regard to it. * * *

The Cretaceous rocks of the Upper Missouri have been separated into five divisions upon lithological and paleontological grounds, and the sandstone formation at the mouth of Big Sioux and below forms the type of No. $1,{ }^{2}$ Nos. 2 and 3 are seen reposing upon No. 1 at the mouth of Big Sioux, and near the mouth of the Niobrara River No. 4 appears upon the summits of the bluffs, surmounting No. 3. At the foot of the "Big Bend" No. 3 passes beneath the water level of the river and is succeeded by No. 4, which occupies the country to Grand River, where No. 5 makes its appearance on the summits of the hills. Near the mouth of the Cannonball River the Lignite Tertiary beds begin to overlap the Cretaceous strata but do not entirely conceal them along the banks of the river until we reach "Square Buttes," about 30 miles below Fort Clarke. From this point to Milk River in latitude $48^{\circ}$, longitude $106^{\circ}$, only the Miocene beds of the Great Lignite basin are exposed. *** The Tertiary beds continue uninterrupted until we reach the mouth of Milk River, where, by a reverse dip of the strata, the Cretaceous formation rises to the surface from beneath the Tertiary. The Tertiary beds continue to overlap the Cretaceous, gradually thinning out upon the summits of the hills, until we reach the mouth of the Muscle Shell River, where the Cretaceous bed No. 4 occupies the whole country. We thus see that in ascending the Missouri the dip of the strata is northwest as far as Fort Union or some point in that vicinity, and on reaching Milk River we can very distinctly observe the dip south or southeast, by which. the underlying Cretaceous beds are exposed. We can also note the basin-like form in which both Tertiary and Cretaceous rocks were deposited. Passing the mouth of the Muscle Shell we soon observe a somewhat remarkable bed rising above the water level of the Missouri, near the mouth of Little Rocky Mountain Creek, which, from its lithological character and position, we have hitherto considered as belonging to formation No. 1. It first makes its appearance as a seam of carbonaceous grit, of a dull-reddish color, very light and loose, like ashes, about 1 foot in thickness, separating No. 4 from a bed of sandstone beneath. As we ascend the river a bed of sandstone rises rapidly above the water level, very variable in its lithological character. ***

Thus far up the river we have observed no indications of disturbance of strata by subterranean influences, but on reaching a point about 5 miles above Grand Island a great thickness of rocks not before seen is uplifted so as to exhibit the beds, inclining at every angle from a horizontal to a vertical position. The beds are composed of variegated sands, clays, and earthy lignite, and some of them are fully charged with' organic remains. * * *

About 10 miles below the mouth of the Judith River the marine strata of No. 1 are seen to rise rapidly from beneath the estuary and fresh-water beds, and on reaching the mouth of the Judith we have the following vertical section of No. $1,^{3}$ the estuary and fresh-water beds only capping the hills and soon ceasing to appear.

It is evident that Hayden realized that the beds exposed along Missouri River from Little Rocky Mountain Creek west to Judith River are older than his No. 4 (now called Bearpaw). The stratigraphic succession between the mouth of Musselshell River and Judith River as given in the above quotation is-

No. 4 .

Fresh and brackish water beds.

No. 1.

In 1875 Meek and Hayden announced independently (see p. 106) that the upper part of Hayden's No. 1 had been definitely correlated with the Fox Hills. In 1877 Cope $^{4}$ corroborated

1 Hayden, F. V., Geological sketch of the estuary and fresh-water deposit of the badlands of the Judith, with some remarks upon the surrounding formations: Am. Philos. Soc. Trans., new ser., vol. 11, pp. 126-130, 1860.

2 Nos. 1 to 5 correspond to Dakota, Benton, Niobrara, Pierre, and Fox Hills, respectively.-C. F. B.

3 The No. 1 of this paragraph refers to what are now called the Eagle and Claggett formations.-C. F. B.

${ }_{4}$ Cope, E. D., Report on the geology of the region of the Judith River, Montana, and on vertebrate fossils obtained on or near the Missouri River; U. S. Geol. and Geog. Survey Terr. Bull., vol. 3, p. 568, 1877. 
the succession established by Hayden, but divided Hayden's No. 1 into three formations. Discussing the section at the mouth of Judith River, Cope said:

The ferruginous soft sandstone of the Fox Hills group is everywhere the line of demarkation between the black shales of No. 4 below and the Judith River beds above.

and, in the preceding paragraph,

A question remains as to the light-colored (buff or white) sandstone underlying No. 4. * * * Geographically considered it is approximately No. 3 , since it occupies a region between that occupied by Nos. 4 and 5 and Fort Benton, where No. 2 is extensively exposed.

With these changes and additions the above section becomes:

6. "No. 4" (Pierre shale).

5. Judith River formation.

4. "No. 5" (Fox Hills sandstone).

3. "No. 4" (Pierre shale).

2. "No. 3 " (?), sandstone tentatively referred to the Niobrara formation.

1. "No. 2" (Benton shale).

Cope ${ }^{1}$ recognized, however, that No. 4 at the mouth of Judith River does not agree in all respects with No. 4 exposed farther east on Missouri River. After discussing the underlying beds (now called Eagle) he says the characteristic overlying shale (Claggett) "is from 50 to 200 feet in thickness in the region of the Judith River, while on the lower river [Missouri] * * * it exhibits a thickness of nearly 1,000 feet above the water level."

Substituting lithologic terms for names, the above section is as follows:
6. Marine shale.
5. Fresh-water formation.
4. Marine sandstone.
3. Marine shale.
2. Marine sandstone.
1. Marine shale.

This is identically the same lithologic succession as that established on Missouri River in 1903 by Stanton and Hatcher, and as that which occurs throughout the area described by the writer in the first part of this paper. Moreover, the work of Pepperberg ${ }^{2}$ in 1908 and of the writer ${ }^{3}$ in 1912 shows that the same succession occurs east of the Bearpaw Mountains from Missouri River north to Milk River.

It is thus evident that this succession of formations prevails over a large area in northcentral Montana. In part of that area the normal sequence is undisturbed by faulting, so that the succession is established beyond question. This succession is shown in the following section, in which the lithologic designations of the preceding section are replaced by the geologic names now applied by the United States Geological Survey to the formations:

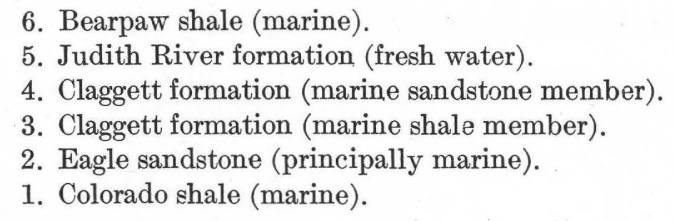

CORRELATION OF JUDITH RIVER FORMATION ON MISSOURI RIVER WITH THE FORMATION IMMEDIATELY UNDERLYING THE BEARPAW SHALE FARTHER SOUTH.

That the formations described by Hayden and Cope which occur at the mouth of Judith River are identical with those shown on the accompanying map (Pl. X) has been shown in the discussion of the stratigraphy (pp. 96-103). Two of these formations-the Claggett (including the so-called Fox Hills sandstone) and the Judith River-were traced continuously for more than 100 miles and were found to be exact equivalents of those at the mouth of Judith River.

1 Op. cit., p. 566.

2 Pepperberg, L. J., The Milk River coal field, Montana: U. S. Geol. Survey Bull. 381, pp. 82-107, 1910.

3 Bowen, C. F., The Cleveland coal field, Blaine County, Montana: U. S. Geol. Survey Bull. 541, pp. 338-353, 1914. 
Peale has also shown the continuity of the Claggett (called by him Pierre and Fox Hills) from the mouth of Judith River southward to Deerfield and has recognized that the formations in the type area of the Judith River formation can be traced with certainty as far south as the North Moccasin Mountains, so that the correlation here made seems to be well established. Peale's statement ${ }^{1}$ in this connection is as follows:

The dark-colored shales of the Pierre resting on these sandstones [Eagle, but called Belly River by Peale] form the surface of the bench beginning several miles to the eastward of the coal mine [near Deerfield] and the road to Kendall passes over them, several good outcrops showing, especially to the north of the road, but they do not show on the Judith south of the mouth of Warm Spring Creek. However, the Pierre shales appear in the valley long before Fullerton is reached and at the latter place form the bluffs on both sides of Judith River in typical exposures containing characteristic fossils. The entire thickness does not show at Fullerton, but there is here an exposure of at least 400 feet. The total thickness is probably from 600 to 900 feet. Immediately below the Judith River beds, which form the summit of the bluffs and the surface of the bench reaching to the eastward, there are from 50 to 100 feet of sandstone with Halymenites major and the following invertebrate fossils: Avicula nebrascana E. and S., Tancredia americana M. and H., Lunatia subcrassa M. and H., Tellina equilateralis M. and H., and Mactra sp. These are identified by Dr. Stanton and referred by him to the Claggett, but it seems to me they are undoubtedly of Fox Hills age, the beds containing them resting on Pierre shales and being immediately followed above by the Judith River beds. * * *

A short distance below Fullerton the first of three well-marked faults that occur south of Judith Landing crosses Judith River. The direction of this fault is nearly east and west and the dip of the beds thrown down is quite steep (about $20^{\circ}$ ) toward the northwest. This outcrop, mainly of Fox Hills sandstone and a smaller part of Judith River beds, is underlain by Pierre shales, and above the faulted beds are Pierre shales capped by Fox Hills sandstones (containing invertebrates and Halymenites major) which underlie the undisturbed Judith River beds, which have a very slight inclination to the north or northwest. The lower slope of the hill back to the faulted beds is composed of Pierre shales capped with Fox Hills sandstones and overlying Judith River beds. This fault line was afterward crossed.12 miles to the eastward, near the crossing of Dog Creek. The second fault line parallel to this one is exactly like the first, but the third one, a few miles south of Judith Landing, is a block fault of Fox Hills sandstone with a steep dip on the southwest side.

In order to establish further the correlation of the Judith River formation in Hayden's type area of that formation with the formation which the writer has mapped as Judith River in the area represented on Plate $\mathrm{X}$, the following list of fossils is presented. This list shows the fossils collected from the Judith River formation in the type area and those collected east and south of T. 19 N., R. 19 E.

\section{Fossils collected from the Judith River formation.}

In Hayden's type area.

Ostrea subtrigonalis E. and S. Corbicula cytheriformis $\mathrm{M}$. and $\mathrm{H}$. Corbicula occidentalis $\mathrm{M}$. and $\mathrm{H}$. Corbula subtrigonalis $\mathrm{M}$. and $\mathrm{H}$. Goniobasis convexa M. and $\mathrm{H}$. Goniobasis invenusta M. and $\mathrm{H}$. Goniobasis sublævis $\mathrm{M}$. and $\mathrm{H}$. Goniobasis judithensis Stanton. Goniobasis gracilinta Meek. Goniobasis subtortuosa M. and H. Campeloma vetula $\mathrm{M}$. and $\mathrm{H}$. Sphærium planum $\mathrm{M}$. and $\mathrm{H}$. Sphærium recticardinale $M$. and $H$. Anomia gryphorhynchus Meek. Unio danæ $M$. and $H$. Unio primævus White. Physa copei White. Hyalina occidentalis M. and $\mathrm{H}$. Hyalina evansi M. and $\mathrm{H}$. Valvata montanaensis Meek. Viviparus conradi M. and $\mathrm{H}$. Anodonta propatoris White.
East and south of T. 19 N., R. 19 E.

Ostrea subtrigonalis E. and $\mathrm{S}$.

Corbicula cytheriformis $\mathrm{M}$. and $\mathrm{H}$.

Corbicula occidentalis $\mathrm{M}$. and $\mathrm{H}$.

Corbula subtrigonalis $\mathrm{M}$. and $\mathrm{H}$.

Goniobasis sublævis M. and $\mathrm{H}$.

Goniobasis subtortuosa M. and H.

Sphærium sp.

Anomia sp.

Unio sp.

Viviparus conradi M. and $\mathrm{H}$.

Anodonta propatoris White. 
The list of fossils from the southern part of the field differs from the Missouri River list only in being less complete. A full collection from the southern area and a specific determination of all the forms would doubtless duplicate most if not all of those in the Missouri River list.

In addition to this duplication of species there is at many places, both on Missouri River and in the southern part of the field, a bed of Ostrea subtrigonalis at the top of the Judith River formation. This Ostrea bed is perhaps the best index bed in the Judith River formation, as it occurs immediately beneath the Bearpaw shale. The widespread occurrence of this bed at the same geologic horizon is therefore of itself sufficient evidence to establish the correlation of the formation in which it occurs within a single basin of deposition, although it may not be sufficient to establish a correlation of beds in separate basins.

It seems to the writer that the evidence presented in the foregoing discussion shows conclusively that the Judith River formation in the type area along Missouri River is the exact equivalent of the beds which immediately underlie the Bearpaw shale in the adjacent areas north and south of Missouri River, and therefore that the Judith River formation is of Montana age. This evidence may be briefly summarized as follows:

1. The stratigraphic succession in the two areas is identical.

2. The invertebrate fossils of the Judith River formation on Missouri River are identical with those in the formation underlying the Bearpaw shale farther south.

3. The bed of Ostrea subtrigonalis which occurs at the top of the Judith River formation on the Missouri also occurs at many places at the top of the formation underlying the Bearpaw shale in the area south of Missouri River.

4. Two of the formations, the Claggett and Judith River, have been traced from Willow Creek, in the southern part of the area, to the mouth of Judith River and found to be the exact equivalents of the Judith River and underlying formations at that place.

One question may still be raised, namely, May there not be two formations (Belly River and Judith River of Peale and some others) which in Hayden's "type area" have been confused and included under one name? As there has never been a complete detailed survey of Hayden's "type area," this question can not be unequivocally answered in the negative. If this confusion exists, Hayden's section (see p. 109) would need to be revised so as to show two fresh-water formations below his "lignite Tertiary." Such a succession is hardly probable, however, as it is now well known that no such sequence of formations occurs either north or south of Hayden's "Judith River area." Furthermore, Stanton and Hatcher failed to find any such succession in that part of the "type area" which they examined in 1903. It is possible, however, that, owing to the highly disturbed condition of the strata, down-faulted blocks of the Lance formation may occur in some places in Hayden's "original area." If such blocks exist they are undoubtedly of small extent, and it is confidently believed that most if not all of the "estuarine deposits" described by Hayden belong, as indicated by him, to the same formation which he describes as capping the hills at the mouth of the Judith. This formation, as previously shown, is the equivalent of the Judith River formation on Willow Creek and there undoubtedly underlies the Bearpaw shale. (See Pl. X.)

\section{PALEONTOLOGIC EVIDENCE OF THE AGE OF THE JUDITH RIVER FORMATION.}

As shown in the historical summary (pp. 104-110), the Judith River formation was regarded by the earlier geologists as overlying the Fox Hills sandstone and was therefore supposed to be of late Cretaceous or early Tertiary age, notwithstanding the fact that the vertebrate remains were regarded as indicating a close relationship with the Cretaceous.

The stratigraphic relation of the Judith River to the inclosing formations has been discussed above. In the following pages the paleontologic evidence of the age of the Judith River formation is submitted. In this connection it is necessary to compare the fauna of the so-called Fox Hills sandstone of the Judith River area (the marine sandstone forming the upper part of the Claggett) with the fauna of the underlying Eagle sandstone, and also with that of the Fox Hills at its type locality, and to compare the fauna of the Judith River formation with that of the Belly River formation on the one hand and with that of the Lance 
formation on the other. The writer has therefore assembled as complete lists as possible of the fauna of these formations, which are presented in tabular form in order to facilitate comparison. But before proceeding with this comparison the paleobotanic evidence of the age of the Judith River formation is briefly considered.

\section{THE FLORA OF THE JUDITH RIVER FORMATION.}

Although stems and fragments of plants are common in the Judith River formation, wellpreserved leaves which will serve for purposes of identification are extremely rare and have been obtained at only two localities-on Cow Creek near Missouri River, and on Willow Creek about 10 miles north of Musselshell post office. Both collections were made by Stanton and Hatcher in 1903 and were submitted to F. H. Knowlton for identification and determination of age. Knowlton's descriptions and conclusions are published in Survey Bulletin 257, pages 129 to 168, and the final paragraph of his article is quoted here:

From this review it appears that the flora of the Judith River beds that has thus far come to light shows very little affinity with the true Laramie or the Fort Union but does exhibit an undoubted relationship with that of the Dakota group or with the Cenomanian and Senonian of the Old World, or, in broad terms, with the lower and middle portions of the Upper Cretaceous.

Knowlton's statements regarding the specimens collected on Cow Creek are rather guarded, and Peale ${ }^{1}$ has argued that the species represented by this collection is of Fort Union age. Knowlton's statement regarding this species is therefore quoted here in full: ${ }^{2}$

From the base of the Judith River beds, at a point on Cow Creek, about 13 miles above its mouth, Mr. Stanton has obtained about 15 specimens of small detached leaves or leaflets that I am not able to distinguish from this species [Trapa microphylla]. While they are all smaller than the usual examples from the type locality (Point of Rocks, Wyo.), they agree well in shape and the marginal dentation, but unfortunately have not retained the nervation, or, at most, but slight traces of it. This species, or at least what has been so identified, has been figured by Dawson, in Tyrrell's collections from Bad Lands, Red Deer, and Rosebud rivers, and Pincher Creek, Canada, the age of which he regards as "Lower Laramie," and also a single doubtful example "from the Upper Laramie of Great Valley."

Prof. Ward found this species abundantly at Burns ranch, on lower Yellowstone River, Mont., in beds supposed to be of Fort Union age, but, as I have shown in the "Flora of the Montana formation," I can not believe that these should be referred to T. microphylla, for the reason that they are clearly compound leaves, rarely detached, whereas at the type locality and at all the points mentioned by Dawson they are always separated and show no evidence of having been compound. I found examples that are not to be distinguished, apparently, from the Burns ranch forms, on Wolverine Creek, in the Yellowstone National Park, in beds regarded as of true Laramie age, and in $1896 \mathrm{Mr}$. Stanton and myself found a large number of detached leaves in Converse County, Wyo., in clay beds in the lower portion of the true Laramie. It may be that my presumption of two forms being mixed under this name is not valid, but it is certainly remarkable that at two localities they should always give evidence of being compound and at all the other localities appear as detached leaves, with no indication of being compound, especially as the material is ample in most cases. It must be confessed, however, that when dealing with isolated leaves or leaflets it is impossible to draw any satisfactory line between them.

This quotation shows that there is no doubt as to the Montana age of the plants from Willow Creek, and that Knowlton also favors the correlation of the species from Cow Creek with the Montana rather than the Fort Union flora. Peale, ${ }^{3}$ in discussing the Willow Creek section, from which the leaves identified by Knowlton were obtained, says that the "Belly River beds [Judith River formation of this paper] pass conformably beneath the soft dark shales of the Pierre," and " there can be no doubt as to the Belly River age of these beds." There is thus a unanimity of opinion regarding the Belly River age of the formation exposed on Willow Creek. The writer has endeavored to show (pp. 101, 110-112) that this so-called Belly River formation (Judith River of this paper) on Willow Creek is the exact stratigraphic equivalent of the Judith River formation at the mouth of Judith River. The invertebrate fossils listed on page 111 bear similar evidence. The stratigraphic evidence and the evidence furnished by the fossil plants and invertebrates, therefore, point to the same conclusion, namely, that the Judith River formation is older than the Bearpaw shale and is of Montana age.

\footnotetext{
1 Jour. Geology, vol. 20, p. 739, 1912.

2 U. S. Geol. Survey Bull. 257, pp. 144-145, 1905.

${ }^{3}$ Op. cit., p. 549.
} 
INVERTEBRATES OF THE UPPER PART OF THE CLAGgeTT FORMATION (SO-CALLED FOX HILLS OF THE JUDITH RIVER AREA) COMPARED WITH THOSE OF THE EAGLE SANDSTONE AND THE FOX HILLS PROPER.

The following table gives a complete list of invertebrates from the Eagle sandstone and the sandstone member constituting the upper part of the Claggett at the mouth of Judith River; also a comprehensive list of Fox Hills fossils collected near the type locality in the Cheyenne and Standing Rock Indian reservations of North and South Dakota.

TABLE 2.-Invertebrate fossils from the Eagle sandstone, the upper part of the Claggett formation, and the type locality of the Fox Hills sandstone.

NoтE.-References indicated by figures in the table are as follows: ${ }^{1}$ Calvert, W. R., and others, Geology of the Cheyenne and Standing

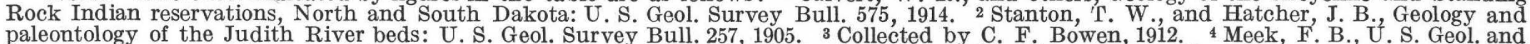

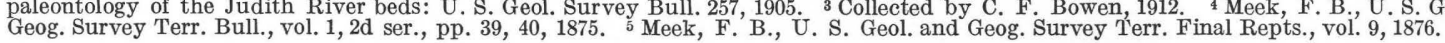

\begin{tabular}{|c|c|c|c|}
\hline & $\begin{array}{c}\text { Eagle } \\
\text { sandstone. }\end{array}$ & $\begin{array}{l}\text { Upper part } \\
\text { of Claggett } \\
\text { formation. }\end{array}$ & $\begin{array}{l}\text { Fox Hills } \\
\text { sandstone. }\end{array}$ \\
\hline Anchura americana (E. and S.).......... & & & \\
\hline $\begin{array}{l}\text { Anomia micronema Meek... } \\
\text { Avicula linguiformis } \mathrm{E} \text {. and } \mathrm{s} . \ldots \ldots \ldots \ldots \ldots \ldots\end{array}$ & & & $\times 1$ \\
\hline A vicula nebrascana E. and S..................... & & $\times 23$ & $\begin{array}{l}\times 14 \\
\times 14\end{array}$ \\
\hline Baculites ovatus Say............... & & $x^{3}$ & \\
\hline $\begin{array}{l}\text { Callista deweyi } \mathrm{M} \text {. and } \mathrm{H} . . . \\
\text { Callista }\end{array}$ & $X^{2}(?)$ & & $x^{1}$ \\
\hline $\begin{array}{l}\text { Callista pellucida } \mathrm{M} \text {. and } \mathrm{H} . . . . \\
\text { C... }\end{array}$ & $x^{3}$ & $x^{5}$ & \\
\hline Cantharus vaughani M. and $\mathrm{H}$. . & $x$ & & \\
\hline Cardium speciosum M. and H......... & $\times 23$ & $\times 235$ & \\
\hline Cerithiopsis moreauensis $\mathrm{M}$. and $\mathrm{H} . . . . . .$. & & & $\hat{x}^{i}$ \\
\hline 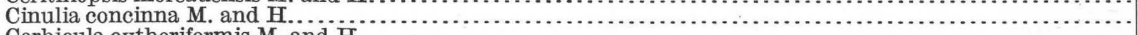 & & & $\hat{x}^{1}$ \\
\hline Corbicula cytheriformis M. and H........ & & & $\times 1$ \\
\hline & & & $\hat{x}_{1}^{1}$ \\
\hline $\begin{array}{l}\text { lorbicula subelliptica var. moreauensis M. and } \mathrm{H} \text {... } \\
\text { Cucullæa nebrascensis Owen. }\end{array}$ & & & $\begin{aligned} x^{1} \\
\times 1\end{aligned}$ \\
\hline $\begin{array}{l}\text { Cuculnaa nebrascensis } \\
\text { Cucullæa shumardi } \mathrm{M} \text {. and } \mathrm{H} . . . . . \\
\end{array}$ & & & $\begin{array}{l}x_{1}^{1} \\
x_{1}\end{array}$ \\
\hline Cuspidaria ventricosa M. and $\mathrm{H} . .$. & & & $x^{1}$ \\
\hline Cylichna volvaria $\mathrm{M}$. and $\mathrm{H} . . . . . .$. & & & $\hat{x}^{i}$ \\
\hline Dentalium gracile $\mathrm{H}$. and $\mathrm{M} . . . . . . . . .$. & & & $\begin{array}{l}x \\
\times 1\end{array}$ \\
\hline 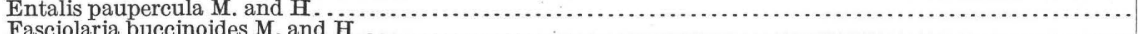 & & $\cdots \cdot$ & $\begin{aligned} x_{1} \\
x_{1}\end{aligned}$ \\
\hline $\begin{array}{l}\text { Fasclolarla buccmooldes } \mathrm{M} \text {. and } \\
\text { Fasciolaria (Piestochilus) culbertsoni } \mathrm{M} \text {. and } \mathrm{H} . \cdots\end{array}$ & & & \\
\hline Fasciolaria (Piestochilus) searboroughi E. and S.. & & & $\begin{array}{l}x_{1}^{1} \\
x^{1}\end{array}$ \\
\hline Fusus ( Serrifusus) dakotensis M. and $\mathrm{H} . . . . . . . .$. & & & $x^{1}$ \\
\hline Gervillia subtortuosa M. and $\mathrm{H} . . . . . . . . .$. & & & $x^{1}$ \\
\hline $\begin{array}{l}\text { Glycimeris occidentalis } \mathrm{M} \text {. and } \mathrm{H} \text {. } \\
\text { Goniom } \mathrm{va} \text { americana } \mathrm{M} \text { and } \mathrm{H}\end{array}$ & & $x^{5}$ & \\
\hline $\begin{array}{l}\text { Goniomya americana } \mathrm{M} . \text { and } \\
\text { Haminea minor M. and } \mathrm{H} . . . .\end{array}$ & & & $\begin{array}{l}x^{1} \\
x^{1}\end{array}$ \\
\hline Inoceramus cripsii Mantell........ & & $x^{5}$ & \\
\hline Inoceramus pertenuis $\mathrm{M}$. and $\mathrm{H}$. & & $\widehat{x}^{35}$ & \\
\hline Leda (Yoldia) evansi M. and H.. & & & 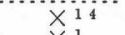 \\
\hline Leda (Yoldia) scitula M. and $\mathbf{H} \ldots \ldots \ldots$. & & & $\times 1$ \\
\hline $\begin{array}{l}\text { Limopsis striato-punctata } \mathrm{E} \text {. and } \mathrm{S} . . . . \\
\text { Linearia? formosa } \mathbf{M} \text {. and } \mathrm{H} . . . . .\end{array}$ & & $\cdots$ & $\times 1$ \\
\hline 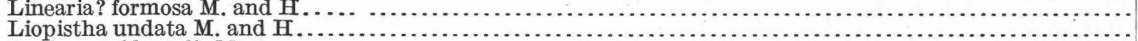 & & $\times 25$ & \\
\hline Lucina occidentalis Morton & & $x=0$ & $x^{1}$ \\
\hline Lucina subundata $\mathrm{H}$. and $\mathrm{M} .$. & $x^{2}$ & & $\cdots$ \\
\hline Lunatia concinna H. and M...................... & & & $\begin{array}{c}x^{1} \\
\times 1\end{array}$ \\
\hline 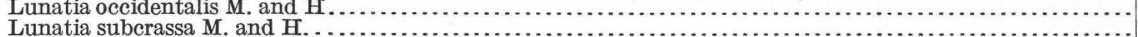 & $x^{2}$ & $\times 235$ & $\begin{array}{l}x^{1} \\
x_{1}^{1}\end{array}$ \\
\hline Mactra alta M. and $\mathrm{H} . . . . . . . . . .$. & & $\hat{X}^{245}$ & $x^{4}$ \\
\hline Mactra formosa M. and $\mathrm{H} . . . . . . .$. & $\hat{x}^{23}$ & $\hat{x}^{234}$ & $\hat{x}^{4}$ \\
\hline Mactra warrenana M. and $\mathrm{H}$. . & & & $\hat{x}^{1}$ \\
\hline Martesis cuneata M. and H........ & & & $\hat{x}^{1}$ \\
\hline Melania insculpta Meek............. & & & $\hat{x}^{1}$ \\
\hline $\begin{array}{l}\text { Mytilus subarcuatus M. and } \mathrm{H} . . . \\
\text { Nantilus }\end{array}$ & & $x^{5}$ & \\
\hline $\begin{array}{l}\text { Nautilus dekayi Morton } \\
\text { Nucula cancellata M. and } \mathrm{H} . . . .\end{array}$ & $x^{2}$ & & \\
\hline Nucula planimarginata $\mathrm{M}$. and $\mathrm{H} . . . . .$. & & & $\hat{x}^{14}$ \\
\hline Ostrea glabra M. and $\mathrm{H} . . . . . . . . . . . . . . .$. & & & $\hat{x}^{1}$ \\
\hline Ostrea pellucida M. and $\mathrm{H} . . . . . . . . . . . .$. & & & $x^{1}$ \\
\hline Ostrea subalata Meek........................ & & & $x_{1}^{1}$ \\
\hline 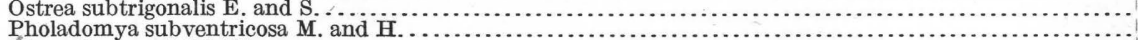 & & & \\
\hline 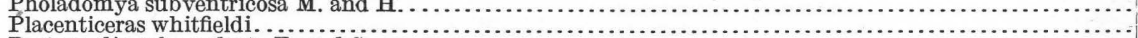 & $\dddot{x} x^{2}$ & & \\
\hline 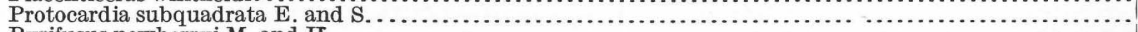 & & & \\
\hline 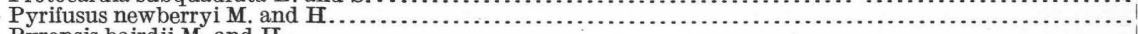 & & & $\hat{x}^{1}$ \\
\hline 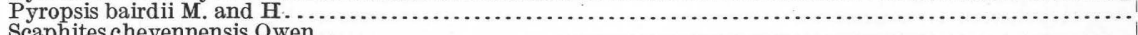 & & & $\times 5$ \\
\hline $\begin{array}{l}\text { Scaphites cheyennensis Owen .................................. } \\
\text { Scaahites conradi Morton }\end{array}$ & & & $\begin{array}{r}x_{1}^{1} \\
\times 1\end{array}$ \\
\hline 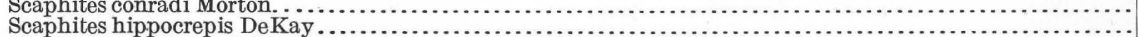 & $x^{2}$ & & \\
\hline 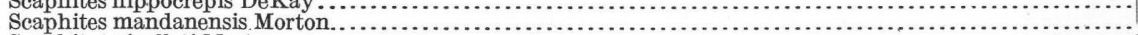 & $x^{2}$ & 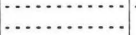 & \\
\hline Scaphites nicolleti Morton.. & .. $>>>$ & ............... & \\
\hline $\begin{array}{l}\text { Scaphites abyssinus Morton. } \\
\text { Snhoriol }\end{array}$ & & & \\
\hline 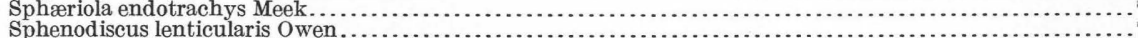 & & $x^{25}$ & $\dddot{x}$ \\
\hline spironema tenuilineata M. and H................ & & & \\
\hline
\end{tabular}


TABLE 2.-Invertebrate fossils from the Eagle sandstone, the upper part of the Claggett formation, and the type locality of the Fox Hills sandstone-Continued.

\begin{tabular}{|c|c|c|c|}
\hline ' & $\begin{array}{c}\text { Eagle } \\
\text { sandstone. }\end{array}$ & $\begin{array}{l}\text { Upper part } \\
\text { of Claggett } \\
\text { formation. }\end{array}$ & $\begin{array}{l}\text { Fox Hills } \\
\text { sandstone. }\end{array}$ \\
\hline Tancredia americana M. and $\mathrm{H}$ & & $\begin{array}{r}\times 245 \\
\times 235\end{array}$ & $X^{15}$ \\
\hline $\begin{array}{l}\text { Tellina equilateralis M. and } \mathrm{H} . . . . . \text {. } \\
\text { Tellina montanaensis............... }\end{array}$ & $x^{2}$ & $X^{235}$ & $\cdots . . .6$ \\
\hline 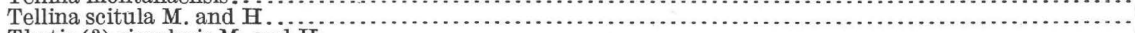 & & & $x^{1}$ \\
\hline 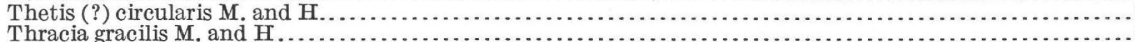 & $x^{2}$ & $\begin{array}{l}X^{3} \\
\times 25\end{array}$ & (n............ \\
\hline 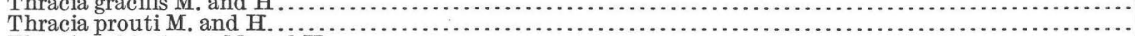 & & $x_{5}$ & \\
\hline 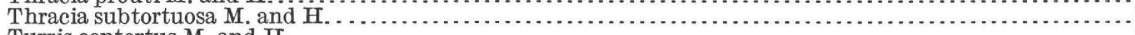 & . & $\hat{x}^{5}$ & ............... \\
\hline Turris contortus $\mathrm{M}$. and $\mathrm{H} . . .$. . & & & $x^{1}$ \\
\hline Vanikoro ambigua $\mathbf{M}$. and $\mathbf{H} . . . . .$. & & & $x^{1}$ \\
\hline Vanikoropsis tuomeyana M. and $\mathrm{H} . . . .$. . & & $\times 235$ & \\
\hline
\end{tabular}

In order to facilitate the interpretation of this table it is summarized in the table below, which gives all the forms that occur in more than one of the formations under discussion.

TABLE 3.-Forms common to two or more of the formations represented in Table 2.

\begin{tabular}{|c|c|c|}
\hline Eagle sandstone. & Upper part of the Claggett formation. & Fox Hills sandstone. \\
\hline 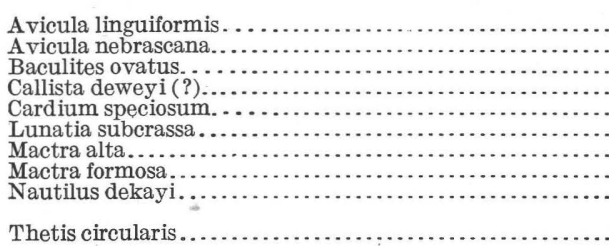 & 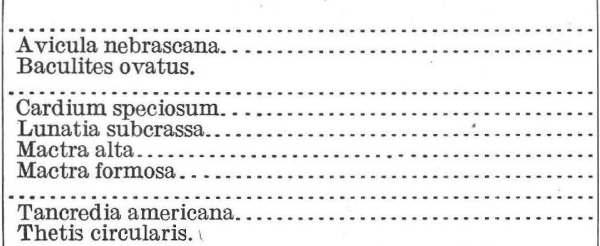 & $\begin{array}{l}\text { Avicula linguiformis. } \\
\text { Avicula nebrascana. } \\
\text { Callista deweyi. } \\
\text { Cardium speciosum. } \\
\text { Lunatia subcrassa. } \\
\text { Mactra alta. } \\
\text { Mactra formosa. } \\
\text { Nautilus dekayi. } \\
\text { Tancredia americana. }\end{array}$ \\
\hline
\end{tabular}

This table shows that there are more species common to the Eagle and Fox Hills in its type locality than to the sandstone in the upper part of the Claggett (so-called Fox Hills) and the Fox Hills proper. It also shows that with one exception (Tancredia americana) every species common to the Claggett and Fox Hills also occurs in the Eagle. Only four specifically determined forms occurring in the Eagle are not found in the higher formations and 12 specifically determined forms found in the Claggett are not found in the Fox Hills. The tables seem to indicate a closer relationship between the faunas of the sandstone division of the Claggett (so-called Fox Hills) and the Eagle than between the former and the Fox Hills proper. They also show that the fauna of the Fox Hills, while related to that of the two older formations, is more diversified, just as the fauna of the Bearpaw shale is related to that of the shales of the Claggett formation but more diversified. From the paleontologic evidence there seems to be no basis for assigning the marine sandstone in the upper part of the Claggett formation to the Fox Hills sandstone, and therefore one of the principal arguments for assigning the Judith River formation to a position at the top of the Cretaceous or base of the Tertiary-namely, that it overlies the Fox Hills sandstone-loses its force. As shown on preceding pages the stratigraphic evidence is conclusive that the Judith River formation is much older than the Fox Hills as represented at its type locality.

INVERTEBRATES OF THE JUDITH RIVER FORMATION COMPARED WITH THOSE OF THE BELLY RIVER AND LANCE FORMATIONS.

A comparison of the invertebrates from the Belly River and Judith River formations with those from the Lance formation of Hell Creek, Mont., and Converse County, Wyo., is given in the following table. This list has been compiled from the lists published by Hayden and Stanton and from the collections made by the writer and his assistants in 1912. 
TABLE 4.-Invertebrate fossils from the Belly River and Judith River formations and the Lance formation of Hell Creek, Mont., and Converse County, Wyo.

References indicated by figures in the table are as follows: 1 Stanton, T. W., U. S. Geol. Survey Bull. 257, pp. 104-119, 1905. 2 Stanton, T. W., Washington Acad. Sci. Proc., vol. 11, pp. 243-247, 1909. ${ }^{3}$ Collected by C. F. Bowen, 1912. ${ }^{4}$ Hayden, F. V., Am. Philos. Soc. Trans., vol. 11, p. 132,1860 .

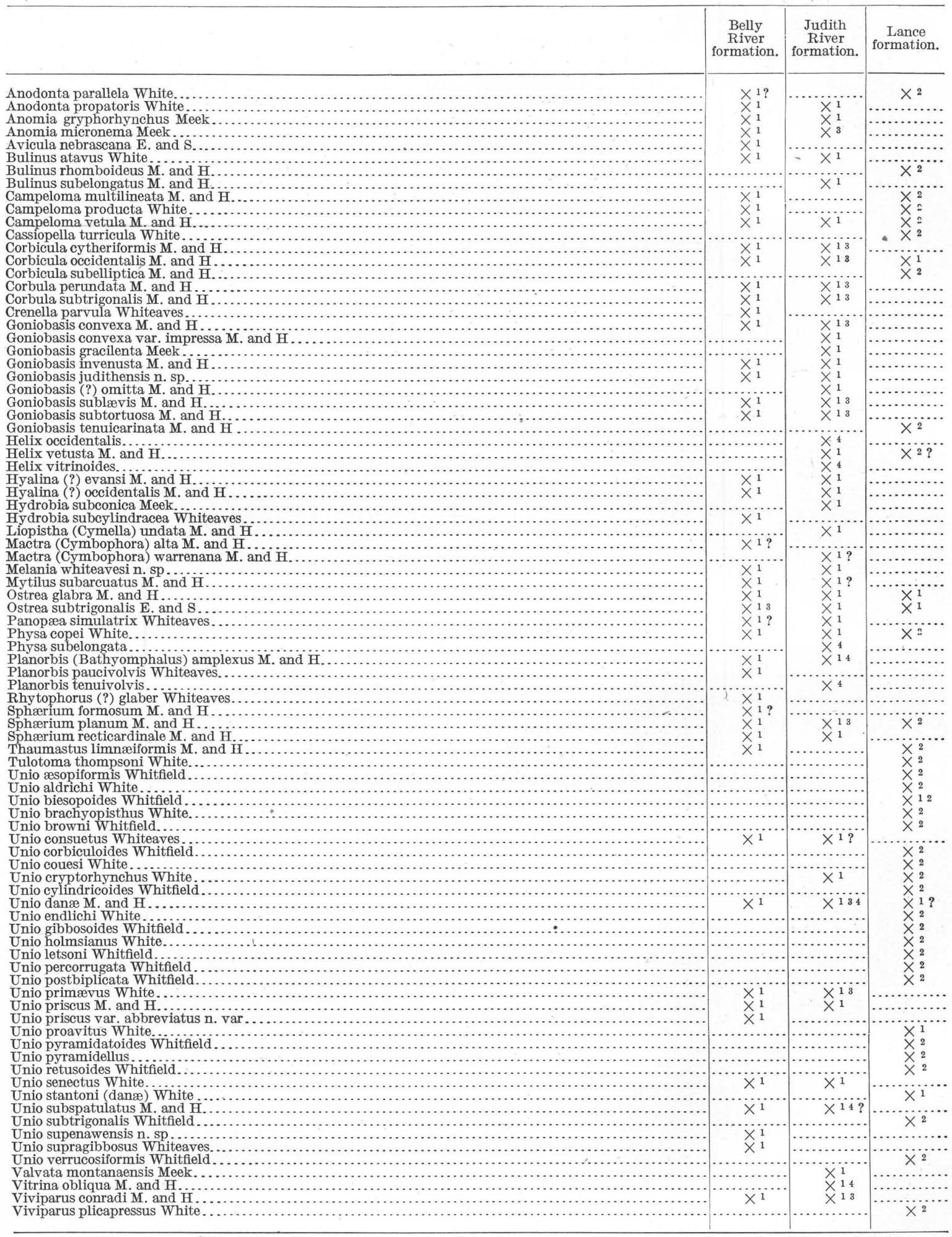

This table is summarized in the following complete list of the forms common to two or more of the formations involved: 
TABLE 5.-Forms which occur in more than one of the formations represented in Table 4.

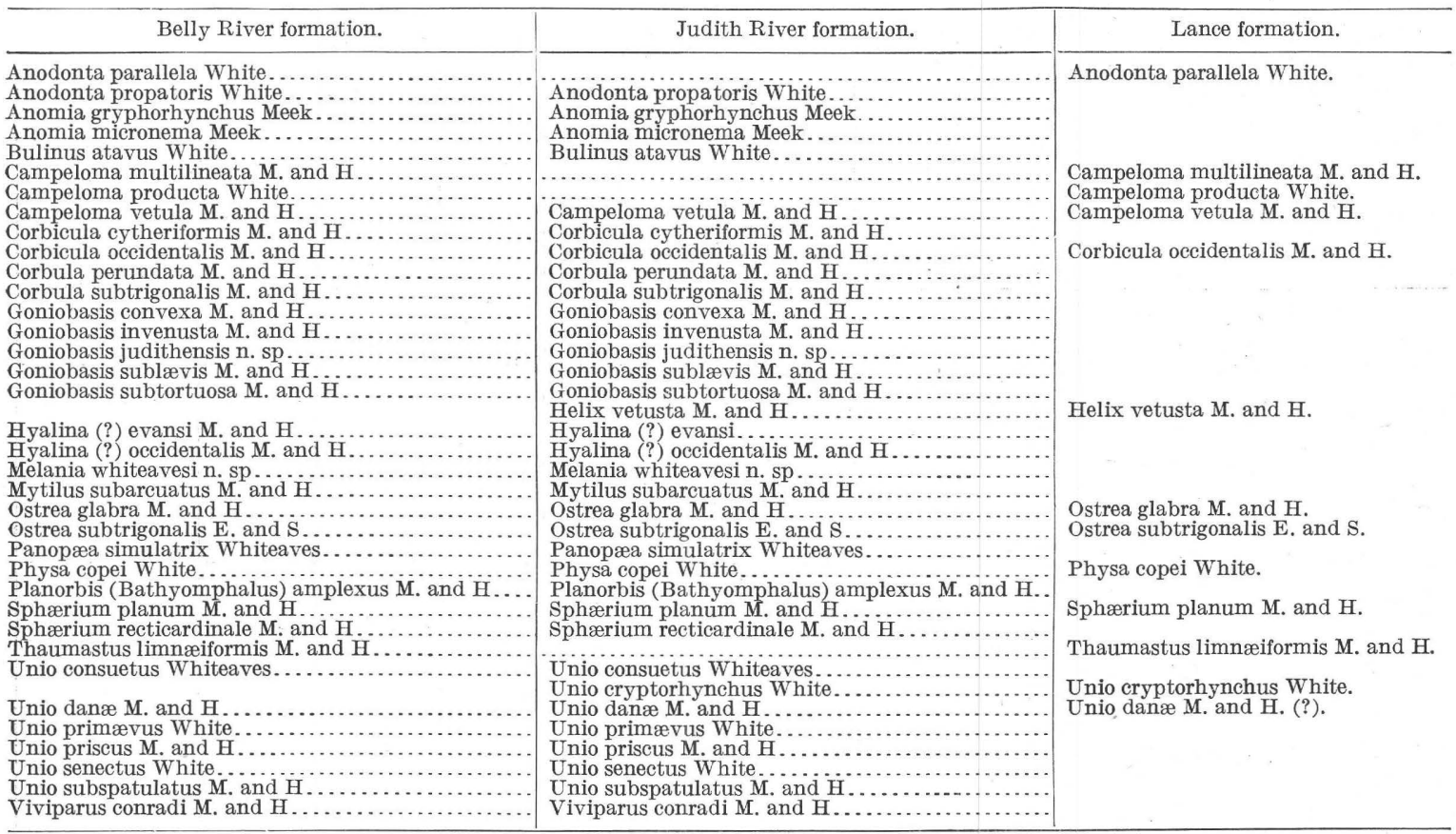

This summary shows that of 88 forms listed in the preceding table 19 genera and 38 species occur in two or more of the formations involved. Of these 38 species only 2 occur in the Judith River and Lance which do not also occur in the Belly River and 4 species occur in the Belly River and Lance but not in the Judith River. There are 32 species common to the Judith River and Belly River, 9 common to the Judith River and Lance, and 7 common to all three formations. Although it is generally conceded that fresh and brackish water invertebrates are of less value than marine invertebrates for the determination of age and correlation of formations, except in local basins, the large number of forms common to the Judith River and Belly River as contrasted with those common to the Judith River and the Lance seems to be significant, and if the fresh-water forms have any weight whatever they certainly favor the correlation of the Judith River and Belly River rather than that of the Judith River and the Lance, and therefore they tend to establish the Cretaceous age of the Judith River formation.

VERTEBRATES OF THE JUDITH RIVER FORMATION COMPARED WITH THOSE OF THE BELLY RIVER AND LANCE FORMATIONS.

In Table 6 is presented a complete list of vertebrates from the Belly River formation; the Judith River formation; the Lance formation of Hell Creek, Mont., Converse County, Wyo., ${ }^{1}$ and adjacent localities; the Denver and Arapahoe formations of the Denver Basin; and the "Laramie" formation of Black Buttes, Wyo. A similar but less comprehensive table was published by Osborn, ${ }^{2}$ and most of the literature and determinations have been reviewed by Hatcher ${ }^{3}$ and Hay. ${ }^{4}$

These publications have served as a basis for the present compilation, though the writer has examined also most of the original descriptions and for doubtful species practically all the literature available. The table gives the name of the species, the formations in which it is reported to have been found, the finder and date (where known), the location at which each specimen has been found, the material on which each determination is based, the authority and reference for the determination, and a column of remarks in which is given mainly a synopsis of the views of the authorities who have reviewed and criticized the original determinations and the material on which those determinations were based.

1 Converse County has been subdivided and the areas referred to in the table are now in Niobrara County.

2 Osborn, H. F., Distinctive characters of the mid-Cretaceous fauna: Contr. Canadian Paleontology, vol. 3, pt. 2, pp. 11-15, 1902.

${ }^{3}$ Hatcher, J. B., Geology and paleontology of the Judith River beds: U. S. Geol. Survey Bull. 257, pp. 67-103, 1905; The Ceratopsia: U. S. Geol. Survey Mon. 49, 1907.

4 Hay, O. P., The fossil turtles of North America: Carnegie Inst. Washington Pub. 75, 1908. 
TABLE 6.-Geologic distribution of vertebrates in the Belly River, Judith River, Lance [The numbers 1 to 6 used in the last six columns correspond to the numbers printed in heavy type over

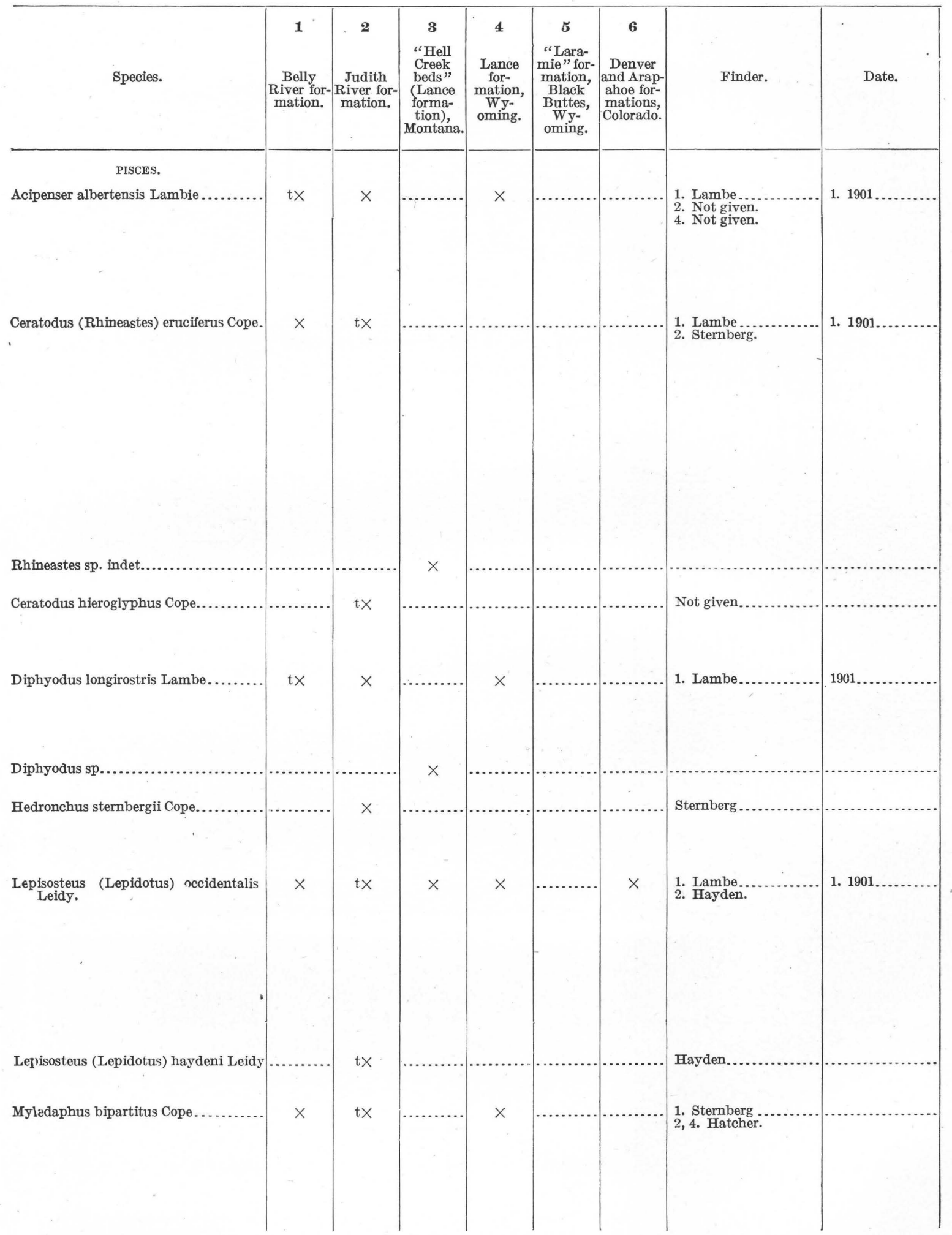


("Hell Creek beds" and "Ceratops beds"), and Denver and Arapahoe formations.

the locality columns. The letter $t$ indicates that the observation relates to the type of the species.]

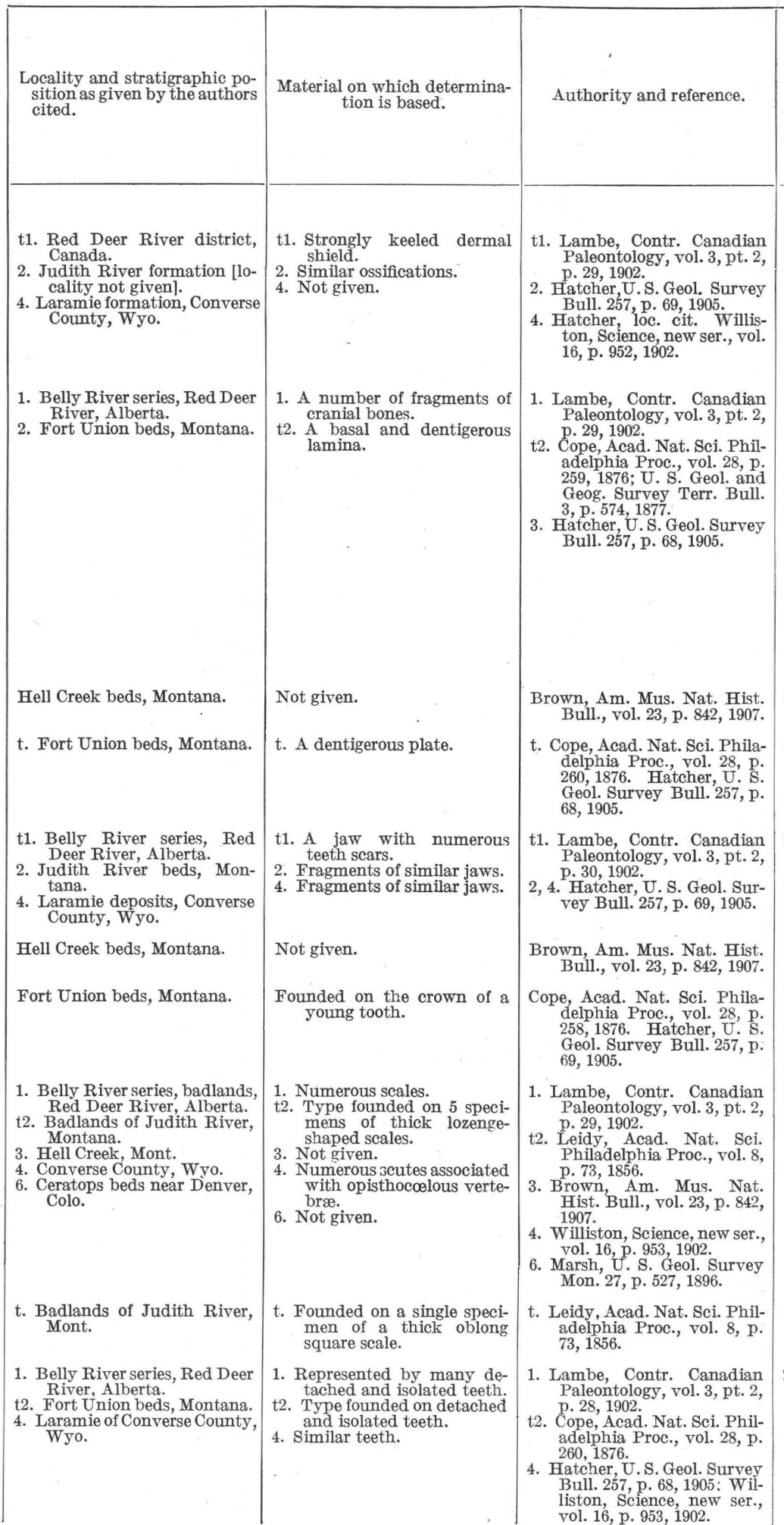

2,4 . Of this and the 7 species which follow, Hatcher (op. cit., p. 67) says: "They are at present known from such insufficient material as to render them of little value for purposes of correlation." Hatcher says ossifications similar to the type material from Canada are common in the Judith River formation and in the Laramie (Lance for-
mation) of Converse County, Wyo.

2. Although Cope gives the locality and horizon as Fort Union, Mont., the horizon is Judith River. Cope at that time was using Fort Union in the same broad sense that was given to Laramila he uses the expression "Fort Union badlands of the Judith River," and on pad$512-574$ of U. S. Geol. and Geog. Survey Terr. Bull. 3 he gives a list of fossils from the Judith River formations, which includes all but one of the species described in the article in the Academy Proceedings. He therefore used the terms Judith River formation and Fort Union formation indiscriminately when referring to the Judith River area. (See also remarks on $A$ ctpenser albertensis.)

See remarks on Acipenser albertensis.

See remarks on Acipenser albertensis and Ceratodus eruciferus.

2, 4. Referring to the type material, Hatcher says: "Fragments of similar jaws are found both in the Judith River beds and in the remarks on Acipenser albertensis.

See remarks on Acipenser albertensis and Ceratodus eruciferus.

See remarks on Acipenser albertensis.

Cope (U. S. Geol. and Geog. Survey Terr. Bull. 3, p. 574, 1877) makes $L$. occidentalis and $L$ haydeni synonymous.

2. Given also in list from Judith River formation, Cope, U. S. Geol. and Geog. Survey Terr. Bull. 3, p. 574, 1877. Hatcher (U. S. Geol. Survey Bull. 257 , p. 68 says: "It would era or, spec vol. 16, p. 953, 1902. 
TABLe 6.-Geologic distribution of vertebrates in the Belly River, Judith River, Lance

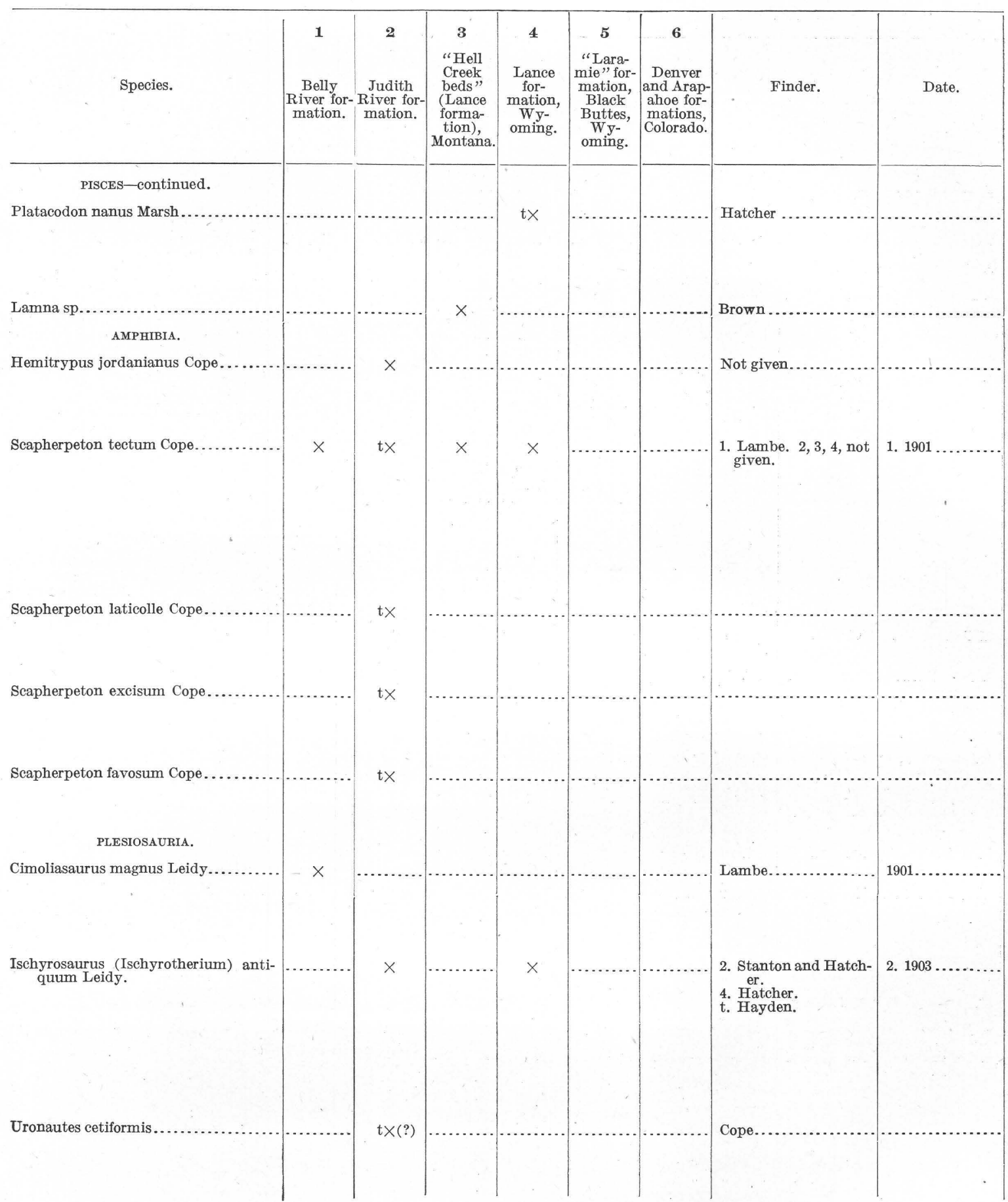


("Hell Creek beds" and "Ceratops beds"), and Denver and Arapahoe formations-Continued.

\begin{tabular}{|c|c|c|c|}
\hline $\begin{array}{l}\text { Locality and stratigraphic po- } \\
\text { sition as given by the authors } \\
\text { cited. }\end{array}$ & $\begin{array}{l}\text { Material on which determina- } \\
\text { tion is based. }\end{array}$ & Authority and reference. & Remarks. \\
\hline $\begin{array}{l}\text { t. Laramie of Converse County, } \\
\text { Wyo. }\end{array}$ & $\begin{array}{l}\text { t. Detached teeth, two dental } \\
\text { plates with teeth in posi- } \\
\text { tion. }\end{array}$ & $\begin{array}{l}\text { Marsh, Am. Jour. Sci., 3d ser., } \\
\text { vol. 38, p. 178, } 1889 . \\
\text { Hatcher, Science, new ser., } \\
\text { vol. 12, p. 719, 1900; Carne- } \\
\text { gie Mus. Annals, vol. 1, p. } \\
\text { 128, 1901. }\end{array}$ & $\begin{array}{l}\text { When first described by Marsh this animal was } \\
\text { regarded as a mammal. The finding of } \\
\text { more complete remains enabled Hatcher to } \\
\text { determine its true relationship. }\end{array}$ \\
\hline Hell Creek beds, Montana. & Not given. & $\begin{array}{l}\text { Brown, Am. Mus. Nat. Hist. } \\
\text { Bull., vol. 23, p. 842, } 1907 .\end{array}$ & \\
\hline Judith River beds, Montana. & A single vertebra. & $\begin{array}{l}\text { Cope, Acad. Nat. Sci. Phila- } \\
\text { delphia Proc., vol. 28, p. } \\
\text { 358, 1876. Hatcher, U. S. } \\
\text { Geol. Survey Bull. 257, p. } \\
\text { 71, } 1905 \text {. }\end{array}$ & $\begin{array}{l}\text { Distinguished from Scapherpeton by the posi } \\
\text { tion of the foramen chordæ dorsalis. }\end{array}$ \\
\hline $\begin{array}{l}\text { 1. Belly River series, Red } \\
\text { Deer River, Canada, be- } \\
\text { tween Berry Creek and } \\
\text { Dead Lodge Canyon. } \\
\text { t2. Judith River beds, Mon- } \\
\text { tana. } \\
\text { 3. Hell Cieek beds, Montana. } \\
\text { 4. Laramie of Converse Coun- } \\
\text { ty, Wyo. }\end{array}$ & $\begin{array}{l}\text { 1. Several trunk vertebræ and } \\
\text { atlases. } \\
\text { t2. Type founded on a single } \\
\text { vertebra; this was accom- } \\
\text { panied by a fragment } \\
\text { which resembles the artic- } \\
\text { ular portion of the mandi- } \\
\text { ble. } \\
\text { 3. Not given. } \\
\text { 4. Numerous vertebræ and } \\
\text { fragments of the mandible. }\end{array}$ & $\begin{array}{l}\text { 1. Lambe, Contr. Canadian } \\
\text { Paleontology, vol. } 3, \text { pt. 2, } \\
\text { p. } 31,1902 \text {. } \\
\text { t2. Cope, Acad. Nat. Sci. Phil- } \\
\text { adelphia Proc., vol. } 28, \text { p. } \\
\text { 355, 1876. } \\
\text { 3. Brown, Am. Mus. Nat. } \\
\text { Hist. Bull., vol. 23, p. } 823 \text {, } \\
\text { 1907. } \\
\text { 4. Williston, Science, new ser., } \\
\text { vol. 16, pp. 952-953, 1902. }\end{array}$ & \\
\hline t. Judith River beds, Montana. & $\begin{array}{l}\text { t. Founded on an atlas and } \\
\text { several dorsal vertebræ of } \\
\text { different individuals; ver- } \\
\text { tebræ may belong to } S \text {. } \\
\text { tectum. }\end{array}$ & $\begin{array}{l}\text { t. Cope, Acad. Nat. Sci. Phila- } \\
\text { delphia Proc., vol. 28, p. } \\
\text { 356, } 1876 \text {. Hatcher, U. S. } \\
\text { Geol. Survey Bull. } 257 \text {, p. } \\
\text { 70,1905. }\end{array}$ & \\
\hline t. Judith River beds, Montana. & $\begin{array}{l}\text { t. Species founded on scat- } \\
\text { tered vertebræ from three } \\
\text { individuals of different } \\
\text { sizes. }\end{array}$ & $\begin{array}{l}\text { t. Cope, Acad. Nat. Sci. Phila- } \\
\text { delphia Proc., vol. 28, p. } \\
\text { 357, 1876. Hatcher, U. S. } \\
\text { Geol. Survey Bull. 257, p. } \\
\text { 70, } 1905 \text {. }\end{array}$ & \\
\hline t. Judith River beds, Montana. & $\begin{array}{l}\text { t. Species founded on a single } \\
\text { vertebra. }\end{array}$ & $\begin{array}{l}\text { t. Cope, Acad. Nat. Sci. Phila- } \\
\text { delphia Proc., vol. 28, p. } \\
\text { 357, 1876. Hatcher, U. S. } \\
\text { Geol. Survey Bull. 257, p. } \\
\text { 70, 1905. }\end{array}$ & \\
\hline $\begin{array}{l}\text { Belly River series, below Berry } \\
\text { Creek on Red Deer River, } \\
\text { Alberta. }\end{array}$ & $\begin{array}{l}\text { Fourteen cervical vertebræ, } \\
\text { probably belonging to one } \\
\text { individual. }\end{array}$ & $\begin{array}{l}\text { Lambe, Contr. Canadian Pa- } \\
\text { leontology, vol. } 3, \text { pt. } 2 \text {, p. } \\
32,1902 .\end{array}$ & $\begin{array}{l}\text { The type of this species is founded on vertebræ } \\
\text { from the greensands of New Jersey de- } \\
\text { scribed by Leidy in 1853. Hatcher (U. S. } \\
\text { Geol. Survey Bull. 257, p. 71) says: "It is } \\
\text { not improbable that Lambe's material be- } \\
\text { longs to a different genus and species." }\end{array}$ \\
\hline $\begin{array}{l}\text { 2. Judith River beds, Cow } \\
\text { Creek } 6 \text { or } 7 \text { miles above } \\
\text { its mouth, Montana. } \\
\text { 4. Laram ie of Wyoming. } \\
\text { [Foundwith mammals and } \\
\text { reptiles described by } \\
\text { Marsh, probably all from } \\
\text { Converse County, though } \\
\text { no exactlocality is given.] } \\
\text { t. Between Grand and Moreau } \\
\text { rivers, S. Dak. }\end{array}$ & $\begin{array}{l}\text { 2. A number of vertebial cen- } \\
\text { tra. } \\
\text { 4. Several vertebræ. }\end{array}$ & $\begin{array}{l}\text { 2. Hatcher, U. S. Gejl. Sur- } \\
\text { vey Bull. 257, p. } 72,1905 . \\
\text { 4. Marsh, Am. Jour. Sci., 3d } \\
\text { ser., vol. } 38, \text { p. } 83,1889 .\end{array}$ & $\begin{array}{l}\text { 2. Hatcher says the material is so incomplete } \\
\text { that the determination is uncertain. The } \\
\text { type specimen was found by Hayden in } \\
\text { South Dakota between Grand and Moreau } \\
\text { rivers from an "outlier of the great lignite } \\
\text { beds." Hatcher says the horizon was more } \\
\text { nearly that of the Fox Hills or Pierre. }\end{array}$ \\
\hline $\begin{array}{l}\text { Near Armells Creek, Judith } \\
\text { River district, Mont. }\end{array}$ & $\begin{array}{l}\text { Cervical, dorsal, and caudal } \\
\text { vertebræ and portions of } \\
\text { limb and rib bones. }\end{array}$ & $\begin{array}{l}\text { Cope, Acad. Nat. Sci., Phila- } \\
\text { delphia Proc., vol. 28, p. } \\
346,1876 \text {. }\end{array}$ & $\begin{array}{l}\text { Cope regards the horizon as Fox Hills, but his } \\
\text { Fox Hills would be the upper part of the } \\
\text { Claggett formation. Hatcher says that the } \\
\text { specimen came either from the top of the } \\
\text { Claggett or from the base of the Judith } \\
\text { River. }\end{array}$ \\
\hline
\end{tabular}


TaBLe 6.-Geologic distribution of vertebrates in the Belly River, Judith River, Lance

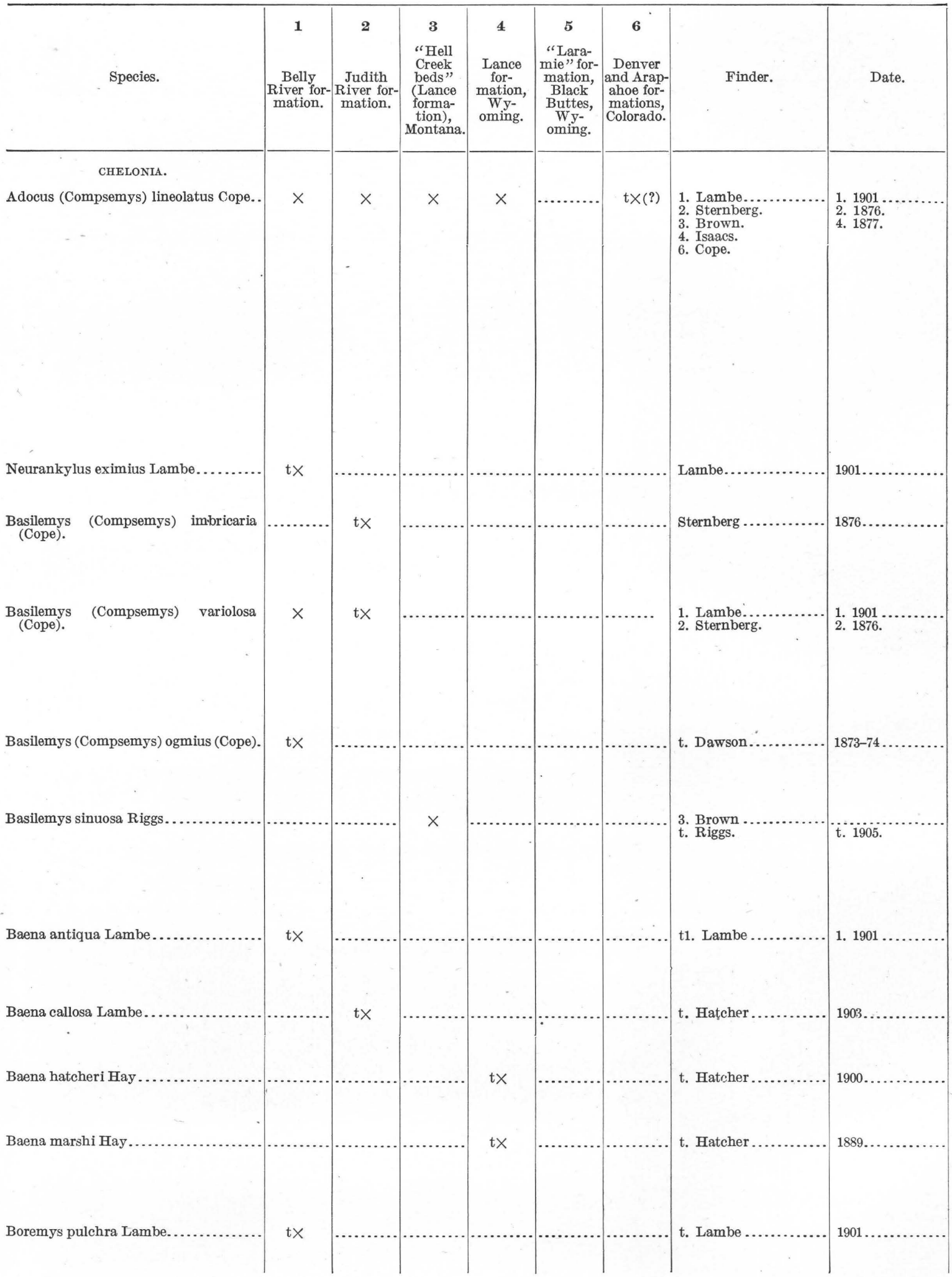


("Hell Creek beds" and "Ceratops beds"), and Denver and Arapahoe formations-Continued.

\begin{tabular}{|c|c|c|c|}
\hline $\begin{array}{l}\text { Locality and stratigraphic po- } \\
\text { sition as given by the authors } \\
\text { cited. }\end{array}$ & $\begin{array}{l}\text { Material on which determina- } \\
\text { tion is based. }\end{array}$ & Authority and reference. & Remarks. \\
\hline $\begin{array}{l}\text { 1. Belly River series, Red Deer } \\
\text { River, Alberta. } \\
\text { 2. Judith River formation, } \\
\text { Montana. } \\
\text { 3. Hell Creek, Mont. } \\
\text { 4. Laramie of Converse County, } \\
\text { Wyo. } \\
\text { t6. Lignite beds of Colorado } \\
\text { [Cross (U. S. Geol. Survey } \\
\text { Mon. 27, p. 244) gives the } \\
\text { horizon as probably Arap- } \\
\text { ahoe. In a personal com- } \\
\text { munication to the writer } \\
\text { G. B. Richardson says: } \\
\text { "No vertebrate remains } \\
\text { are known to occur in the } \\
\text { Laramie of the Denver } \\
\text { Basin." Cross's interpre- } \\
\text { tation of the horizon is } \\
\text { therefore probably right.] }\end{array}$ & $\begin{array}{l}\text { 1. Fragments of right hypo- } \\
\text { plastral, and margin of } \\
\text { carapace. } \\
\text { 2. Fragments of costals. } \\
\text { 3. Fragment of a costal and } \\
\text { peripheral (Hay, loc. cit.) } \\
\text { 4. Fragments of costal and } \\
\text { plastral. } \\
\text { t6. Two fragments, a verte- } \\
\text { bral and sternal, which } \\
\text { constitute the type. }\end{array}$ & $\begin{array}{l}\text { 1. Lambe, Contr. Canadian } \\
\text { Paleontology, vol. 2, p. } 38 \text {, } \\
\text { 1902. } \\
\text { 2. Hay, Fossil turtles of North } \\
\text { America, p. 248, 1908. } \\
\text { Cope, U. S. Geol. and } \\
\text { Geog. Survey Terr. Bull. } \\
\text { 3, p. 573, 1877. } \\
\text { 3. Brown, Am. Mus. Nat. } \\
\text { Hist. Bull., vol. 23, p. 823, } \\
\text { 1907. } \\
\text { 4. Hay, Fossil turtles of North } \\
\text { America, p. 248, 1908. } \\
\text { t6. Cope, U. S. Geol. and } \\
\text { Geog. Survey Terr. Bull. } \\
\text { 1, No. 2, p. 30, 1874. } \\
\text { Hatcher, U. S. Geol. Sur- } \\
\text { vey Bull. 257, p. 75, 1905. }\end{array}$ & $\begin{array}{l}\text { This species was also reported from the mouth } \\
\text { of Bighorn River, Mont. Hatcher thinks } \\
\text { Lambe's determination of the Belly River } \\
\text { specimens may be incorrect. Hay (loc. cit.) } \\
\text { says: "It is unsafe to identify as belonging } \\
\text { to A docus lineolatus specimens from the } \\
\text { Judith River and Laramie [Lance] beds } \\
\text { before far better materials * * * * have } \\
\text { been collected from the type locality } \\
\text { [Bijou Creek, Colo.] * * * It is im- } \\
\text { probable that the species continued from } \\
\text { the Judith River epoch to the Arapahoe } \\
\text { epoch." }\end{array}$ \\
\hline $\begin{array}{l}\text { t. Belly River series, Red } \\
\text { Deer River, Alberta. }\end{array}$ & $\begin{array}{l}\text { t. Several costals representing } \\
\text { a part of the carapace. }\end{array}$ & $\begin{array}{l}\text { t. Lambe, Contr. Canadian } \\
\text { Paleontology, vol. } 3 \text {, pt. } 2 \text {, } \\
\text { p. } 42,1902 .\end{array}$ & \\
\hline $\begin{array}{l}\text { t. Judith River beds, Mon- } \\
\text { tana. }\end{array}$ & $\begin{array}{l}\text { Founded on unsatisfactory } \\
\text { material, only three frag- } \\
\text { ments of which can now be } \\
\text { referred to the type. These } \\
\text { fragments are probably } \\
\text { costal plates. }\end{array}$ & $\begin{array}{l}\text { Hay, Fossil turtles of North } \\
\text { America, p. 231, 1908. } \\
\text { t. Cope, Acad. Nat. Sci. Phila- } \\
\text { delphia Proc., vol. 28, p. } \\
\text { 257, } 1876 \text {. }\end{array}$ & $\begin{array}{l}\text { Hay (loc. cit.) says that the species is founded } \\
\text { on very unsatisfactory material, that the } \\
\text { fragments described belong to more than } \\
\text { one species, and that better material will } \\
\text { be required to determine the structure and } \\
\text { generic position of Cope's } C \text {. imbricarius. }\end{array}$ \\
\hline $\begin{array}{l}\text { 1. Belly River series, Red } \\
\text { Deer River below Berry } \\
\text { Creek, Alberta, and Wil- } \\
\text { low Creek subdivision of } \\
\text { the Laramie. } \\
\text { t2. Judith River beds, Mon- } \\
\text { tana. [Also by Stanton } \\
\text { and Hatcher in the same } \\
\text { formation.] }\end{array}$ & $\begin{array}{l}\text { 1. By Lambe, portions of a } \\
\text { plastron and anterior half } \\
\text { of shell. } \\
\text { t2. Founded on carapace and } \\
\text { plastron. }\end{array}$ & $\begin{array}{l}\text { 1. Lambe, Contr. Canadian } \\
\text { Paleontology, vol. 3, pt. 2, } \\
\text { p. 39, 1902. } \\
\text { 2. Cope, Acad. Nat. Sci. Phila- } \\
\text { delphia Proc., vol. 28, p. } \\
\text { 257, 1876. Hatcher, U. S. } \\
\text { Geol. Survey Bull. 257, p. } \\
\text { 76, 1905. }\end{array}$ & $\begin{array}{l}\text { Eugene Stebinger, of the U. S. Geological Sur- } \\
\text { vey, who has recently mapped the area } \\
\text { from which Dawson obtained the type } \\
\text { specimen of B. ogmius, says that the beds } \\
\text { are undoubtediy of Belly River age. The } \\
\text { material obtained by Dawson was very } \\
\text { fragmentary. Hay (op. cit. p. 229) says: } \\
\text { "It is doubtful whether new materials } \\
\text { could be identified by means of the type." }\end{array}$ \\
\hline $\begin{array}{l}\text { t. Belly River series, six miles } \\
\text { west of the first branch of } \\
\text { Milk River near latitude } \\
49^{\circ} \text { and between longitude } \\
112^{\circ} \text { and } 113^{\circ} \text {. }\end{array}$ & $\begin{array}{l}\text { t. Two small, poorly pre- } \\
\text { served fragments of costal } \\
\text { bones. }\end{array}$ & $\begin{array}{l}\text { t. Dawson, British North } \\
\text { America Boundary Comm. } \\
\text { Rept., p. 130, } 1875 \text {. }\end{array}$ & $\begin{array}{l}\text { B. ogmius is made a synonym of } B \text {. variolosus } \\
\text { by Hay (loc. cit.) and Lambe (op. cit., } \\
\text { p. } 39 .)\end{array}$ \\
\hline $\begin{array}{l}\text { 3. Hell Creek, Dawson County, } \\
\text { Mont. } \\
\text { t. Ceratops beds, Chalk Buttes, } \\
\text { near Powderville, Custer } \\
\text { County, Mont. }\end{array}$ & $\begin{array}{l}\text { 3. Fragments of epiplastral } \\
\text { lip. } \\
\text { t. Whole shell. }\end{array}$ & $\begin{array}{l}\text { 3. Brown, Am. Mus. Nat. } \\
\text { Hist. Bull., vol. 23, p. } 823 \text {, } \\
\text { 1907. Hay, Fossil turtles } \\
\text { of North America, p. 229, } \\
\text { 1908. Field Columbian } \\
\text { t. Riggs, Field } \\
\text { Mus. Pubs., Geol. ser., } \\
\text { vol. 2, p. } 249,1906 .\end{array}$ & . \\
\hline $\begin{array}{l}\text { t1. Belly River series, Red } \\
\text { Deer River below Berry } \\
\text { Creek, Canada. }\end{array}$ & $\begin{array}{l}\text { 1. Part of a carapace, also the } \\
\text { anterior end of a plastron } \\
\text { probably belonging to the } \\
\text { same individual. }\end{array}$ & $\begin{array}{l}\text { 1. Lambe, Contr. Canadian } \\
\text { Paleontology, vol. 3, pt. } \\
\text { 2, p. 44, 1902. Hay, Fos- } \\
\text { sil turtles of North Amer- } \\
\text { ica, p. } 62,1908 \text {. }\end{array}$ & \\
\hline $\begin{array}{l}\text { Judith River beds, Willow } \\
\text { Creek, Mont. }\end{array}$ & $\begin{array}{l}\text { An imperfect carapace and the } \\
\text { greater portion of a plas- } \\
\text { tron. }\end{array}$ & $\begin{array}{l}\text { Hay, Carnegie Mus. Annals, } \\
\text { vol. 3, 1906; Fossil turtles } \\
\text { of North America, p. } 60 \text {, } \\
1908 \text {. }\end{array}$ & \\
\hline $\begin{array}{l}\text { Ceratops beds, Converse Coun- } \\
\text { ty, Wyo., south side of } \\
\text { Lance Creek, opposite the } \\
\text { mouth of Doegie Creek. }\end{array}$ & $\begin{array}{l}\text { t. A carapace and plastron } \\
\text { nearly complete. }\end{array}$ & $\begin{array}{l}\text { t. Hay, Carnegie Mus. Annals, } \\
\text { vol. 1, p. 325, 1902; Fossil } \\
\text { turtles of North America, } \\
\text { p. } 63,1908 \text {. }\end{array}$ & $\begin{array}{l}\text { A specimen from Red Deer River (Belly River } \\
\text { formation), Canada, referred by Lambe to } \\
\text { this species has since been referred to } \\
\text { Boremys pulchra. }\end{array}$ \\
\hline $\begin{array}{l}\text { Laramie deposits, Converse } \\
\text { County, Wyo., between } \\
\text { Lance and Buck creeks. }\end{array}$ & $\begin{array}{l}\text { Cast of the greater portion of } \\
\text { the interior of the shell; the } \\
\text { greater part of the central } \\
\text { portion of the carapace and } \\
\text { most of the left side, and a } \\
\text { large part of the plastron. }\end{array}$ & $\begin{array}{l}\text { t. Hay, Am. Jour. Sci., 4th } \\
\text { ser., vol. 18, p. 261, 1904; } \\
\text { Fossil turtles of North } \\
\text { America, p. 63, 1908. }\end{array}$ & \\
\hline $\begin{array}{l}\text { Belly River series, mouth of } \\
\text { Berry Creek, Red Deer } \\
\text { River, Alberta. }\end{array}$ & $\begin{array}{l}\text { The anterior half of the cara- } \\
\text { pace and the complete } \\
\text { plastron. }\end{array}$ & $\begin{array}{l}\text { t. Lambe, Ottawa Naturalist, } \\
\text { vol. } 19 \text {, p. } 323,1906 \text {. Hay, } \\
\text { Fossil turtles of North } \\
\text { America, p. } 92,1908 \text {. }\end{array}$ & $\begin{array}{l}\text { Originally referred by Lambe to Baena hatcheri, } \\
\text { later to B. pulchra, and finally to the pres- } \\
\text { ent genus and species. Hay also describes } \\
\text { it as Boremys pulchra. }\end{array}$ \\
\hline
\end{tabular}


TABLE 6.-Geologic distribution of vertebrates in the Belly River, Judith River, Lance

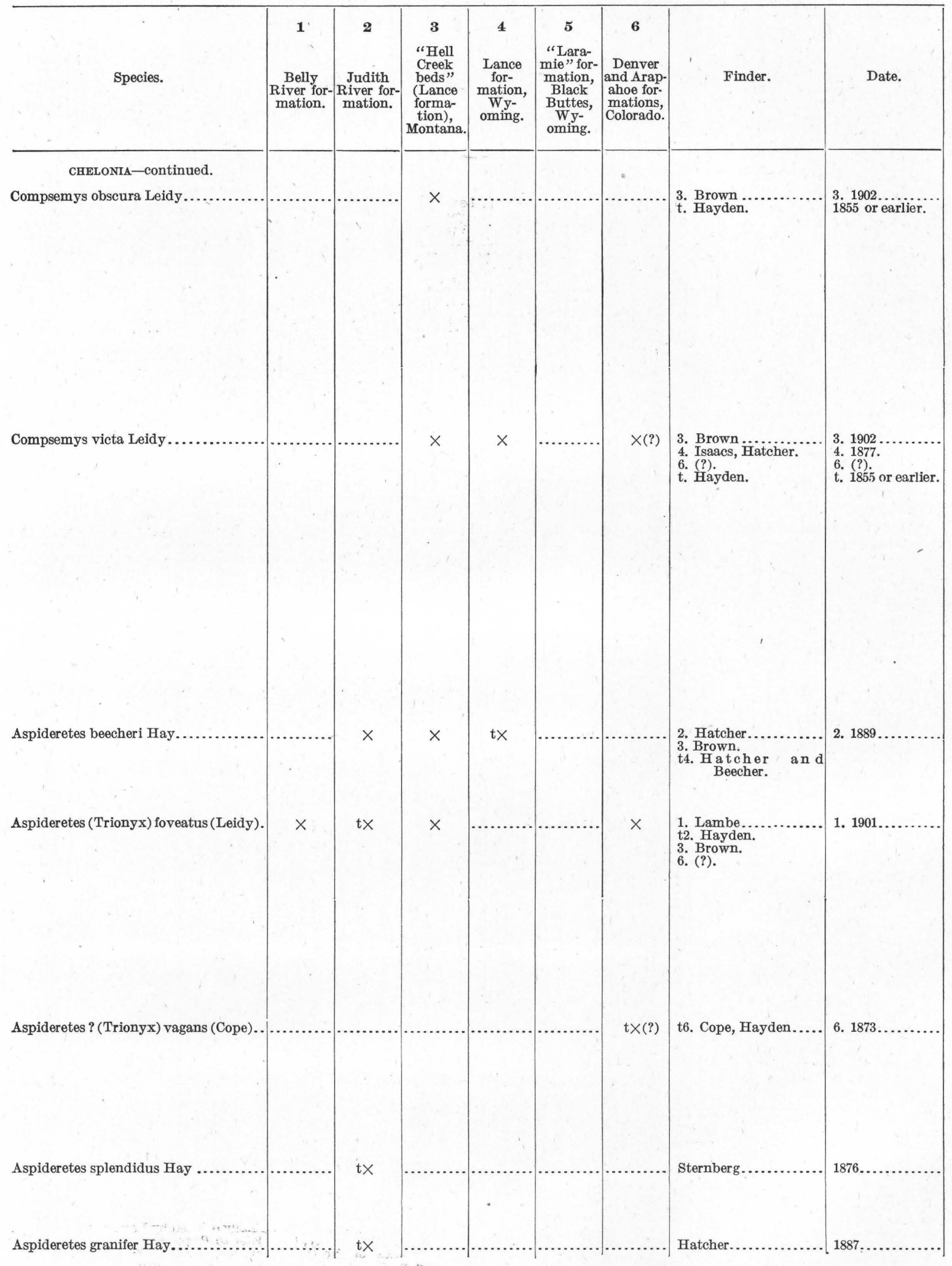


("Hell Creek beds" and "Ceratops beds"), and Denver and Arapahoe formations-Continued.

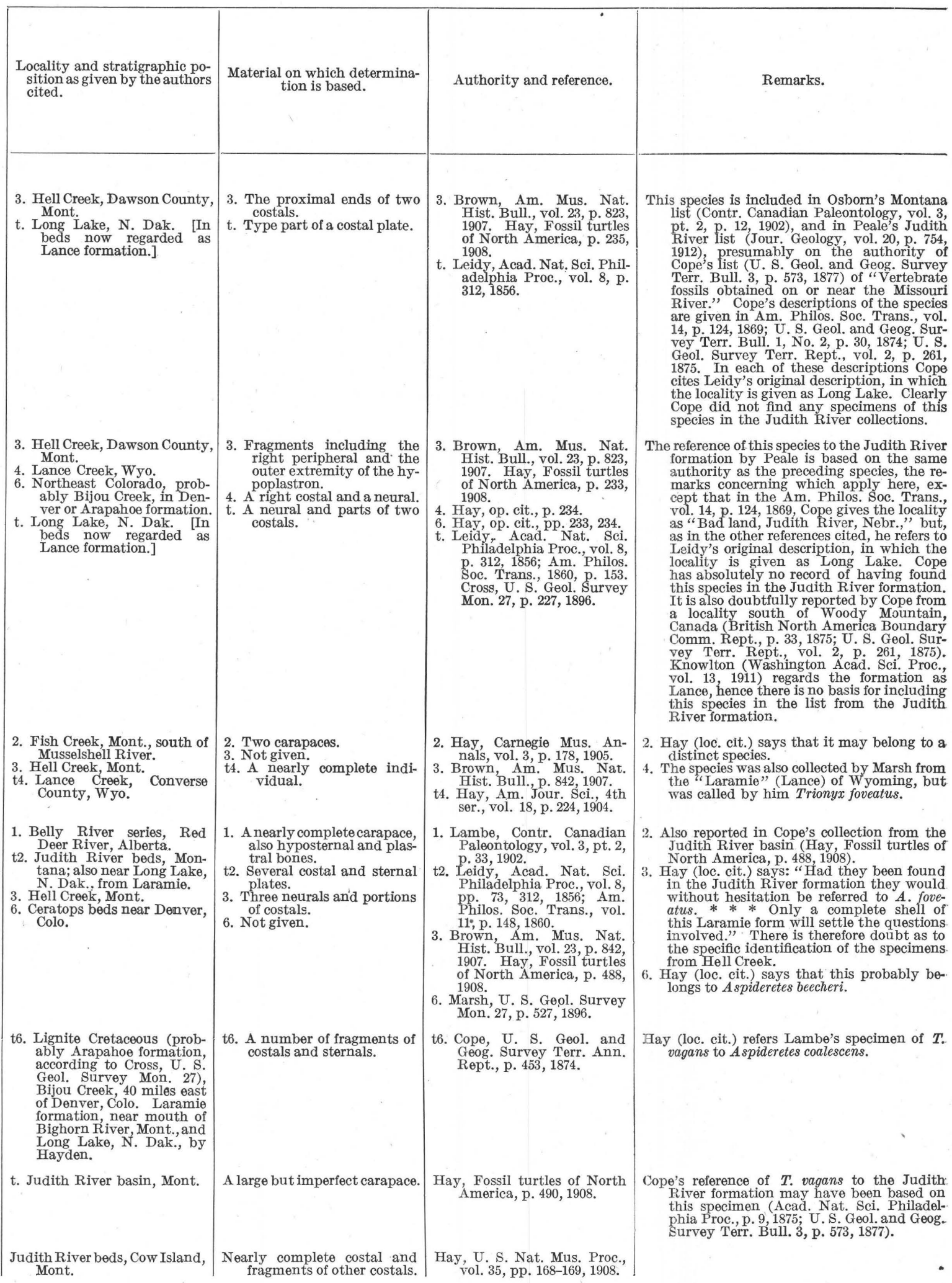


TABLe 6.-Geologic distribution of vertebrates in the Belly River, Judith River, Lance

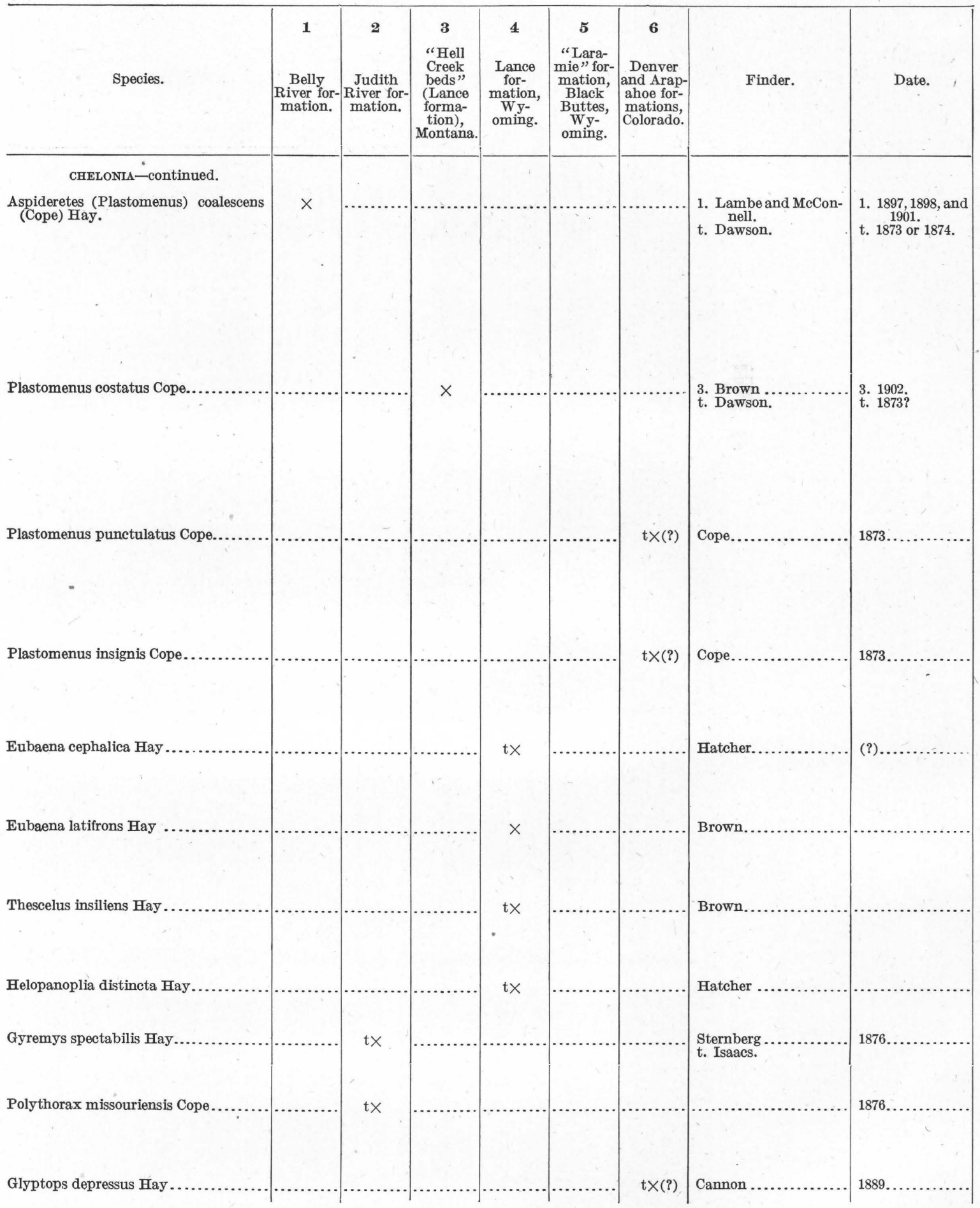


("Hell Creek beds" and "Ceratops beds"), and Denver and Arapahoe formations-Continued.

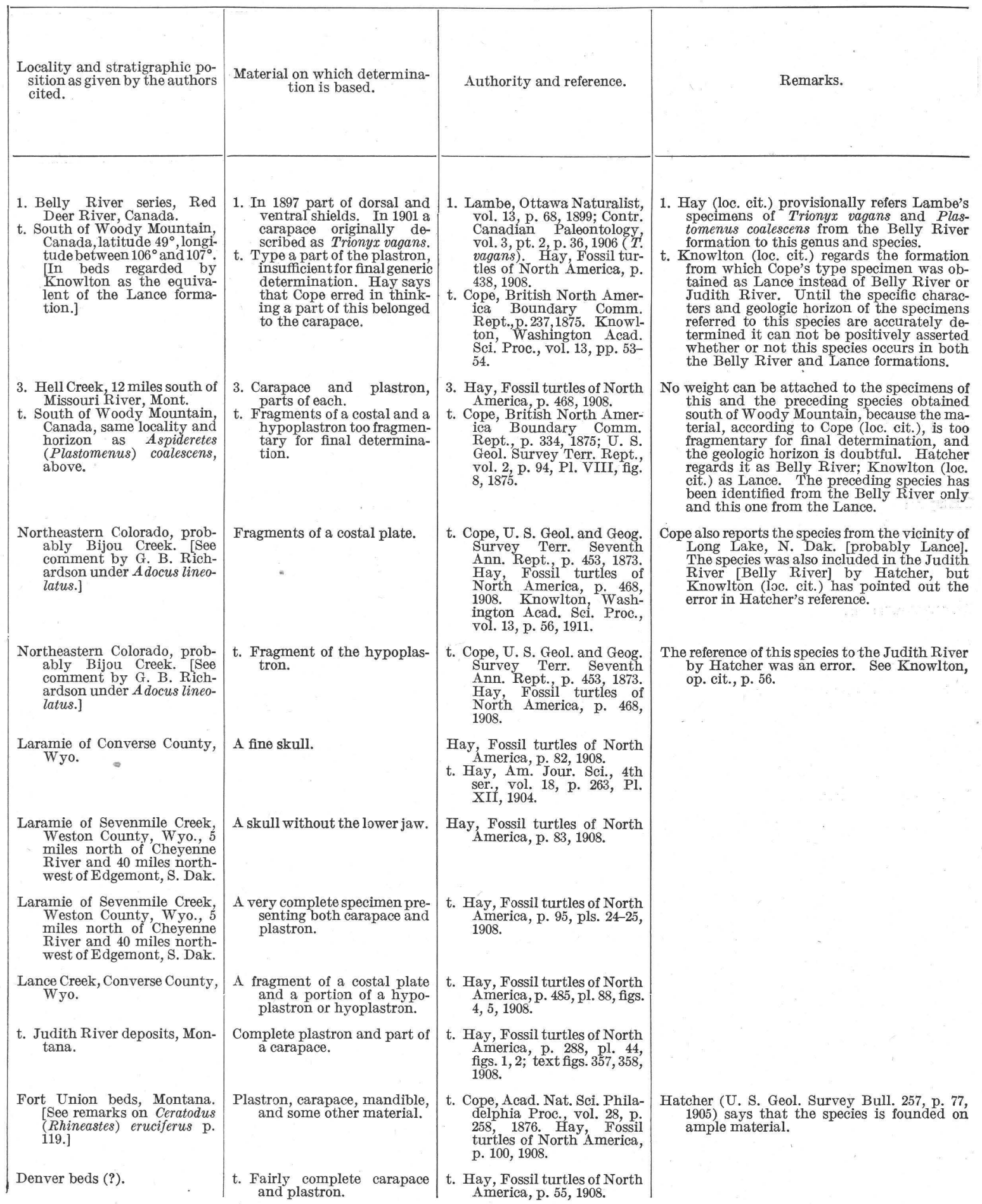


TABLe 6.-Geologic distribution of vertebrates in the Belly River, Judith River, Lance

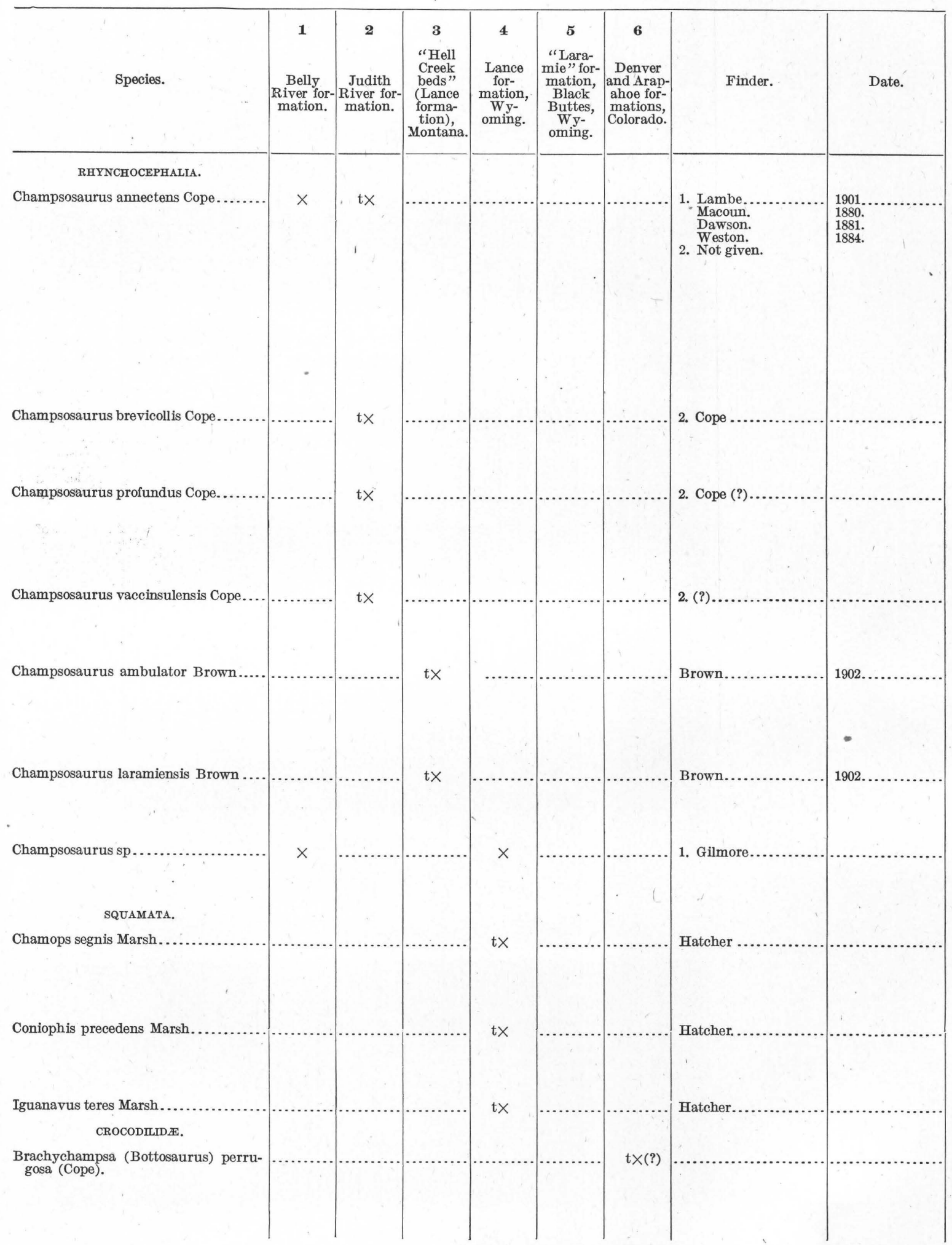


("Hell Creek beds" and "Ceratops beds"), and Denver and Arapahoe formations-Continued.

\begin{tabular}{|c|c|c|c|}
\hline $\begin{array}{l}\text { Locality and stratigraphic po- } \\
\text { sition as given by the authors } \\
\text { cited. }\end{array}$ & $\begin{array}{l}\text { Material on which determina- } \\
\text { tion is based. }\end{array}$ & Authority and reference. & Remarks. \\
\hline $\begin{array}{l}\text { 1. Belly River series, Red Deer } \\
\text { River, Mackay Creek, near } \\
\text { Walsh station, Canadian } \\
\text { Pacific Ry., on Belly } \\
\text { River; Ross Coulee, near } \\
\text { Irwin station, Canada. } \\
\text { 2. Judith River beds, Mon- } \\
\text { tana, and Fox Hills [Clag- } \\
\text { gett formation], Armells } \\
\text { Creek (east of Judith } \\
\text { River), Mont. }\end{array}$ & $\begin{array}{l}\text { 1. A large number of verte- } \\
\text { bræ, none of which were } \\
\text { found together in their } \\
\text { proper relative positions. } \\
\text { t2. Several vertebræ concern- } \\
\text { ing which Cope says he } \\
\text { "can not certainly con- } \\
\text { nect the vertebræ of a } \\
\text { series as those of a single } \\
\text { individual." Brown (loc. } \\
\text { cit.) says that the speci- } \\
\text { men gives good generic } \\
\text { characters, but specific } \\
\text { definition must await bet- } \\
\text { ter material from these } \\
\text { beds. }\end{array}$ & $\begin{array}{l}\text { 1. Lambe, Contr. Canadian } \\
\text { Paleontology, vol. 3, pt. 2, } \\
\text { p. 45, } 1902 \text {. } \\
\text { t2. Cope, Acad. Nat. Sci. Phil- } \\
\text { adelphia Proc., vol. 28, p. } \\
\text { 351, 1876. Brown, Am. } \\
\text { Mus. Nat. Hist. Mem., } \\
\text { vol. } 9, \text { pt. 1, p. 6, } 1905 .\end{array}$ & $\begin{array}{l}\text { 2. Regarding the specimen from the so-called } \\
\text { Fox Hills [Claggett formation], Cope (op. } \\
\text { cit., p. 352) says: "I can not account for } \\
\text { this circumstance, as it is the most abun- } \\
\text { dant fossil of the Judith River beds." As } \\
\text { the Judith River formation is now known } \\
\text { to overlie so-called Fox Hills conformably, } \\
\text { the occurrence is not remarkable. }\end{array}$ \\
\hline $\begin{array}{l}\text { 2. Judith River beds, Mon- } \\
\text { tana. }\end{array}$ & $\begin{array}{l}\text { t2. A weathered axis centrum } \\
\text { of an immature individual, } \\
\text { considered invalid by } \\
\text { Brown (loc. cit.). }\end{array}$ & $\begin{array}{l}\text { t2. Cope, Acad. Nat. Sci. Phil- } \\
\text { adelphia Proc., vol. 28, p. } \\
352 \text {, 1876. Brown, Am. } \\
\text { Mus. Nat. Hist. Mem., } \\
\text { vol. } 9 \text {, pt. } 1 \text {, p. } 6,1905 .\end{array}$ & $\begin{array}{l}\text { Brown (loc. cit.) says that C. brevicollis is } \\
\text { invalid. } \\
\text { Hatcher (U. S. Geol. Survey Bull. } 257 \text {, pp. } 81 \text {, } \\
\text { 82, 1905) says of these species: "Owing to } \\
\text { the fact that these Judith River forms are }\end{array}$ \\
\hline $\begin{array}{l}\text { 2. Judith River beds, Mon- } \\
\text { tana. }\end{array}$ & $\begin{array}{l}\text { t2. A sacral, a cervical, and } 3 \\
\text { dorsal vertebræ believed } \\
\text { to belong to the same ani- } \\
\text { mal, and isolated verte- } \\
\text { bræ of separate individ- } \\
\text { uals. Considered valid by } \\
\text { Brown (loc. cit.). }\end{array}$ & $\begin{array}{l}\text { t2. Cope, Acad. Nat. Sci. Phil- } \\
\text { adelphia Proc., vol. 28, p. } \\
\text { 350, } 1876 . \text { Brown, Am. } \\
\text { Mus. Nat. Hist. Mem., } \\
\text { vol. } 9 \text {, pt. 1, p. } 6,1905 .\end{array}$ & $\begin{array}{l}\text { known almost exclusively from disarticu- } \\
\text { usually very simple and considering the } \\
\text { usurughour of the entire vertebral column in } \\
\text { this group, it may at present be considered } \\
\text { difficult, if not impossible, to distinguish } \\
\text { the Judith River forms from one another } \\
\text { or from the later Laramie forms." "It has }\end{array}$ \\
\hline $\begin{array}{l}\text { 2. Judith River beds, Mon- } \\
\text { tana. }\end{array}$ & $\begin{array}{l}\text { 2. One-half of a vertebral cen- } \\
\text { trum which Brown (loc. } \\
\text { cit.) refers to the order } \\
\text { Plesiosauria. }\end{array}$ & $\begin{array}{l}\text { 2. Cope, Acad. Nat. Sci. Phil- } \\
\text { adelphia Proc., vol. } 28 \text {, p. } \\
\text { 353, 1876. Brown, Am. } \\
\text { Mus. Nat. Hist. Mem., } \\
\text { vol. 9, pt. 1, p. 6, } 1905 .\end{array}$ & $\begin{array}{l}\text { yet to be shown that most of the characters } \\
\text { mentioned by Cope as distinguishing his } \\
\text { species are not present in vertebræ from } \\
\text { different regions of the vertebral column in } \\
\text { the same individual." }\end{array}$ \\
\hline Hell Creek beds, Montana. & Fairly complete skeleton. & $\begin{array}{l}\text { Brown, Am. Mus. Nat. Hist. } \\
\text { Bull., vol. 23, p. 829,1907. } \\
\text { t. Brown, Am. Mus. Nat. } \\
\text { Hist. Mem., vol. 9, pt. 1, } \\
\text { pp. 4, 22-25, pl. 4, fig. 2, } \\
\text { pl. 5, figs. 3, 3a, 5, 5a, 6, 6a, } \\
\text { 14, 15, 1905. }\end{array}$ & \\
\hline $\begin{array}{l}\text { Hell Creek beds, Hell Creek, } \\
\text { Mont. }\end{array}$ & $\begin{array}{l}\text { Nearly complete skull and } \\
\text { skeleton. }\end{array}$ & $\begin{array}{l}\text { t. Brown, Am. Mus. Nat. } \\
\text { Hist. Mem., vol. 9, pt. 1, } \\
\text { pp. 4, 8-22, pls. 1-5, 1905; } \\
\text { Am. Mus. Nat. Hist. Bull., } \\
\text { vol. 23, p. 842, 1907. }\end{array}$ & \\
\hline $\begin{array}{l}\text { 1. Beds of Belly River age } \\
\text { [Two Medicine formation], } \\
\text { Milk River, Mont. } \\
\text { 4. Laramie deposits, Converse } \\
\text { County, Wyo. }\end{array}$ & Not given. & $\begin{array}{l}\text { 1. C. W. Gilmore, oral com- } \\
\text { munication. } \\
\text { 4. Williston, Science, new ser., } \\
\text { vol. } 16, \text { pp. } 952-953,1902 \text {. }\end{array}$ & , \\
\hline $\begin{array}{l}\text { Laramie of Wyoming. [Pre- } \\
\text { sumably Converse County.] }\end{array}$ & $\begin{array}{l}\text { t. Maxillary bone containing } \\
\text { teeth; various other parts } \\
\text { of the skull and skeleton, } \\
\text { including vertebræ, have } \\
\text { been found at different } \\
\text { localities. }\end{array}$ & $\begin{array}{l}\text { t. Marsh, Am. Jour. Sci., 3d } \\
\text { ser., vol. 43, p. } 450,1892 .\end{array}$ & $=$ \\
\hline Ceratops beds, Wyoming. & $\begin{array}{l}\text { A single vertebra, but several } \\
\text { other vertebræ that may } \\
\text { not belong to the same in- } \\
\text { dividual were found at the } \\
\text { same locality. }\end{array}$ & $\begin{array}{l}\text { t. Marsh, Am. Jour. Sci., 3d } \\
\text { ser., vol. } 43, \text { p. } 450,1892 \text {. }\end{array}$ & $\begin{array}{l}\text { The materia described with the type listed } \\
\text { was found according to Marsh at different } \\
\text { localities. It is not certain that it all per- } \\
\text { tains to the same species. }\end{array}$ \\
\hline $\begin{array}{l}\text { Laramie of Wyoming. [Prob- } \\
\text { ably Converse County.] }\end{array}$ & t. Vertebræ. & $\begin{array}{l}\text { t. Marsh, Am. Jour. Sci., 3d } \\
\text { ser., vol. } 43, \text { p. } 450,1892 .\end{array}$ & \\
\hline $\begin{array}{l}\text { 6. Eastern Colorado. ICross, } \\
\text { (U. S. Geol. Survey Mon. } \\
27, \text { p. } 244,1896 \text { ) regards the } \\
\text { formation as Arapahoe. } \\
\text { See also comment by G. B. } \\
\text { Richardson under Adocus } \\
\text { lineolatus, p. } 123 \text {. }\end{array}$ & $\begin{array}{l}\text { t6. Numerous fragments with } \\
\text { vortebræ and portions of } \\
\text { skull. }\end{array}$ & $\begin{array}{l}\text { t6. Cope, U. S. Geol. and } \\
\text { Geog. Survey Terr. Sev- } \\
\text { enth Ann. Rept., p. 452, } \\
\text { 1874. Hatcher, U. S. Geol. } \\
\text { Survey Bull. 257, p. 82, } \\
\text { 1905. }\end{array}$ & $\begin{array}{l}\text { Referred provisionally to this genus by C. W. } \\
\text { Gilmore. The specimen originally de- } \\
\text { scribed by Lambe as B. perrugosus, } \\
\text { from the Belly River formation, has since } \\
\text { been referred by him to Leidyosuchus cana- } \\
\text { densis Lambe. }\end{array}$ \\
\hline
\end{tabular}


TABLE 6.-Geologic distribution of vertebrates in the Belly River, Judith River, Lance

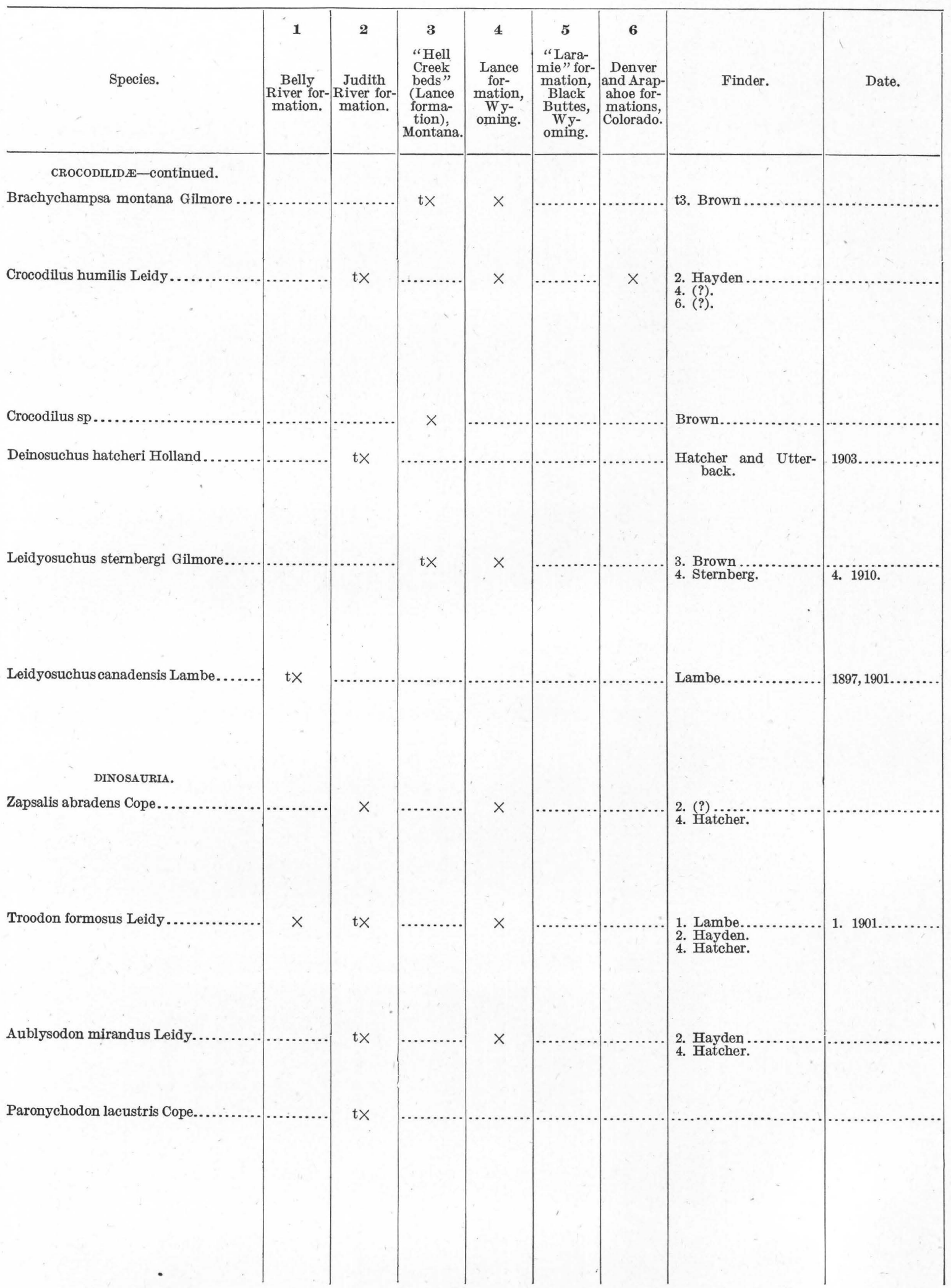


("Hell Creek beds" and "Ceratops beds"), and Denver and Arapahoe formations-Continued.

\begin{tabular}{|c|c|c|c|}
\hline $\begin{array}{l}\text { Locality and stratigraphic po- } \\
\text { sition as given by the authors } \\
\text { cited. }\end{array}$ & $\begin{array}{l}\text { Material on which determina- } \\
\text { tion is based. }\end{array}$ & Authority and reference. & Remarks. \\
\hline $\begin{array}{l}\text { 3. Hell Creek beds, 25 miles } \\
\text { southeast of Lismas, Daw- } \\
\text { son County, Mont. }\end{array}$ & t3. The greater part of a skull. & $\begin{array}{l}\text { t3. Gilmore, U. S. Nat. Mus. } \\
\text { Proc., vol. 41, p. } 297,1912 .\end{array}$ & $\begin{array}{l}\text { 4. "Teeth which can not be distinguished from } \\
\text { those of the type have been found in the } \\
\text { Lance, formation of Converse County, } \\
\text { Wyo." (Oral statement by C. W. Gil- } \\
\text { more.) }\end{array}$ \\
\hline $\begin{array}{l}\text { 2. Badlands of Judith River } \\
\text { [Judith River formation], } \\
\text { Mont. } \\
\text { 4. Ceratops beds, Converse } \\
\text { County, Wyo. } \\
\text { 6. Ceratops beds (on p. } 527 \text { ), } \\
\text { near Denver, Colo.; Den- } \\
\text { ver formation (on p. 227). }\end{array}$ & $\begin{array}{l}\text { t2. Ten specimens of shed } \\
\text { crowns of teeth. } \\
\text { 4. Not given. } \\
\text { 6. Not given. }\end{array}$ & $\begin{array}{l}\text { t2. Leidy, Acad. Nat. Sci. } \\
\text { Philadelphia Proc., vol. } \\
\text { 8,p. 73, 1856. } \\
\text { 4. Williston, Science, new } \\
\text { ser., vol. 16, pp. 952-953, } \\
\text { 1902. } \\
\text { 6. Marsh, U. S. Geol. Survey } \\
\text { Mon. 27, pp. 227, 527, 1896. } \\
\\
\text { Brown, Am. Mus. Nat. Hist. } \\
\text { Bull., vol. 23, p. } 842,1907 .\end{array}$ & $\begin{array}{l}\text { 2. Of Leidy's material Hatcher (U. S. Geol. } \\
\text { Survey Bull. 257, p. 82, 1905) says: "The } \\
\text { simple conical teeth on which the species } \\
\text { was based furnished no characters for the } \\
\text { positive identification of other material." } \\
\text { This species, therefore, seems to be of little } \\
\text { value for correlation. The material from } \\
\text { the Belly River formation originally re- } \\
\text { ferred by Lambe to this species was later } \\
\text { referred by him to Leidyosuchus canadensis. } \\
\text { (See below.) }\end{array}$ \\
\hline $\begin{array}{l}\text { t. Judith River beds, Willow } \\
\text { Creek, Musselshell County, } \\
\text { Mont., } 3 \text { miles west of No- } \\
\text { lan \& Archer's ranch (stage } \\
\text { crossing to Flat Willow). }\end{array}$ & $\begin{array}{l}\text { t. Several scutes, } 2 \text { vertebræ, } \\
1 \text { cervical rib, } 1 \text { dorsal rib, } \\
\text { fragments of ribs and pu- } \\
\text { bis, and several hundred } \\
\text { fragments of bones belong- } \\
\text { ing to the skull, vertebræ, } \\
\text { and ribs, all badly broken. }\end{array}$ & $\begin{array}{l}\text { t. Holland, Carnegie Mus. } \\
\text { Annals, vol. 6, p. 281, } 1909 .\end{array}$ & $\begin{array}{l}\text { A dermal scute referred to this species was } \\
\text { found by C. H. Wegemann in sec. 23, T. } \\
41 \text { N., R. } 79 \text { W., Natrona County, Wyo., } \\
\text { in the Parkman sandstone member of the } \\
\text { Pierre formation, of Montana age (U. S. } \\
\text { Geol. Survey Bull. 452, p. 48, 1911). }\end{array}$ \\
\hline $\begin{array}{l}\text { 3. Hell Creek beds, Gilbert } \\
\text { Creek, Dawson County, } \\
\text { Mont., 135 miles northwest } \\
\text { of Miles City. } \\
\text { 4. Ceratops beds, Converse } \\
\text { County, Wyo., north side } \\
\text { of Cheyenne River, } 3 \text { miles } \\
\text { west of McKeow's ranch. }\end{array}$ & $\begin{array}{l}\text { t3. Greater part of skull. } \\
\text { 4. Greater part of skull, left } \\
\text { ramus almost entire, ante- } \\
\text { rior part of right ramus, } 8 \\
\text { vertebræ, both humeri, } \\
\text { right fibula, metatarsal } \\
\text { and other fragments. }\end{array}$ & $\begin{array}{l}\text { t3. Gilmore, U. S. Nat. Mus. } \\
\text { Proc., vol. } 38 \text {, pp. } 485-502 \text {, } \\
\text { 1911. } \\
\text { 4. Gilmore, idem, p. } 497 \text {. }\end{array}$ & . \\
\hline $\begin{array}{l}\text { Belly River series, Red Deer } \\
\text { River, Alberta. }\end{array}$ & $\begin{array}{l}\text { t. A left mandibular ramus, } \\
\text { posterior part of a cranium, } \\
\text { portions of the skull, teeth, } \\
\text { and a number of vertebræ } \\
\text { and scutes. }\end{array}$ & $\begin{array}{l}\text { t. Lambe, Roy. Soc. Canada } \\
\text { Trans., 3d ser., vol. 1, } \\
\text { sec. 4, p. } 219,1907 .\end{array}$ & $\begin{array}{l}\text { Lambe says: "The jaw was originally de- } \\
\text { scribed as Bottosaurus perrugosus and the } \\
\text { teeth as Crocodilus humilis." He now. con- } \\
\text { cludes that all the material represents a } \\
\text { single species, to which he gives a new name. } \\
\text { It thus appears that } L \text {. canadensis replaces } \\
B \text {. perrugosus and } C \text {. humilis in the Belly } \\
\text { River list of Lambe and Osborn. }\end{array}$ \\
\hline $\begin{array}{l}\text { 2. Judith River beds, Mon- } \\
\text { tana. } \\
\text { 4. Laramie beds, Wyoming. }\end{array}$ & $\begin{array}{l}\text { 2. Detached teeth. } \\
\text { 4. Numerous small teeth. }\end{array}$ & $\begin{array}{l}\text { 2. Cope, Acad. Nat. Sci. Phil- } \\
\text { adelphia Proc., vol. 28, } \\
\text { p. } 345,1876 . \\
\text { 4. Hatcher, U. S. Geol. Sur- } \\
\text { vey Bull. 257, p. } 84,1905 \text {. }\end{array}$ & $\begin{array}{l}\text { 4. Hatcher (loc. cit.) says: "The meager de- } \\
\text { scription given by Cope, without figures, } \\
\text { renders it impossible to certainly identify } \\
\text { any of the forms of teeth known from these } \\
\text { deposits with those referred to by Cope in } \\
\text { his description. * * * Their exact na- } \\
\text { ture must, for the present at least, remain } \\
\text { uncertain." }\end{array}$ \\
\hline $\begin{array}{l}\text { 1. Belly River series, Red } \\
\text { Deer River, below mouth } \\
\text { of Berry Creek, Alberta. } \\
\text { 2. Badlands of Judith River, } \\
\text { Mont. } \\
\text { 4. Laramie of Converse Coun- } \\
\text { ty, Wyo. }\end{array}$ & $\begin{array}{l}\text { 1. Two teeth which agree in } \\
\text { every particular with Lei- } \\
\text { dy's type. } \\
\text { t2. A single tooth, which con- } \\
\text { stitutes the type. } \\
\text { 4. Teeth similar to those de- } \\
\text { scribed by Leidy. }\end{array}$ & $\begin{array}{l}\text { 1. Lambe, Contr. Canadian } \\
\text { Paleontology, vol. 3, pt. } \\
\text { 2, p. 47, 1902. NTat. Sci. } \\
\text { t2. Leidy, Acad. Niat., vol. 8, } \\
\text { Philadelphia Proc., } \\
\text { p. } 72,1856 . \\
\text { 4. Hatcher, U. S. Geol: Sur- } \\
\text { vey Bull. 257, p. } 83,1905 \text {. }\end{array}$ & $\begin{array}{l}\text { Of this and the three succeeding genera Hatcher } \\
\text { (U. S. Geol. Survey Bull. 257, p. 83, 1905) } \\
\text { says: "They are all founded on such frag- } \\
\text { mentary material as to be of little value } \\
\text { except as bearing evidence of the diversity } \\
\text { of the fauna." }\end{array}$ \\
\hline $\begin{array}{l}\text { 2. Badlands of Judith River, } \\
\text { Mont. } \\
\text { 4. Laramie of Wyoming. }\end{array}$ & $\begin{array}{l}\text { t2. Several problematical teeth } \\
\text { originally included by } \\
\text { Leidy in his type of Dei- } \\
\text { nodon horridus. } \\
\text { 4. Teeth. }\end{array}$ & $\begin{array}{l}\text { t2. Leidy, Acad. Na.t. Sci. } \\
\text { Philadelphia Proc., vol. } \\
\text { 20, p. 198, 1868. } \\
\text { 4. Hatcher, U. S. Geol. Sur- } \\
\text { vey Bull. 257, p. } 83,1905 .\end{array}$ & $\begin{array}{l}\text { 2. Probably synonymous with Deinodon } \\
\text { horridus. (See remarks on that species.) } \\
\text { 4. Hatcher (loc. cit.) says: "Similar teeth are } \\
\text { common both in the Judith River and } \\
\text { Laramie." }\end{array}$ \\
\hline $\begin{array}{l}\text { Fort Union of Montana. [Beds } \\
\text { now identified as Judith } \\
\text { River formation.] }\end{array}$ & $\begin{array}{l}\text { t. Detached teeth with sub- } \\
\text { conic crowns. }\end{array}$ & $\begin{array}{l}\text { t. Cope, Acad. Nat. Sci. Phil- } \\
\text { adelphia Proc., vol. } 28, \text { p. } \\
256,1876 \text {. }\end{array}$ & $\begin{array}{l}\text { Hatcher (U. S. Geol. Survey Bull. 257, p. 84, } \\
\text { 1905) regards this species as a synonym of } \\
\text { Aublysodon mirandus. It seems probable, } \\
\text { therefore, that Deinodon horridus, Aublyso- } \\
\text { don mirandus, and Paronychodon lacustris } \\
\text { are synonyms. Osborn (A.m. Mus. Nat. } \\
\text { Hist. Bull., vol. 5, p. 320, 1893) says that } \\
\text { the teeth described by Cope "resemble } \\
\text { those which we have referred to as the } \\
\text { probable lower incisors of Meniscoessus." } \\
\text { Apparently on this ground alone Peale } \\
\text { (Jour. Geology, vol. 20, p. 720, i912) has } \\
\text { included P.lacustris in his Converse County } \\
\text { list. }\end{array}$ \\
\hline
\end{tabular}


Table 6.-Geologic distribution of vertebrates in the Belly River, Judith River, Lance

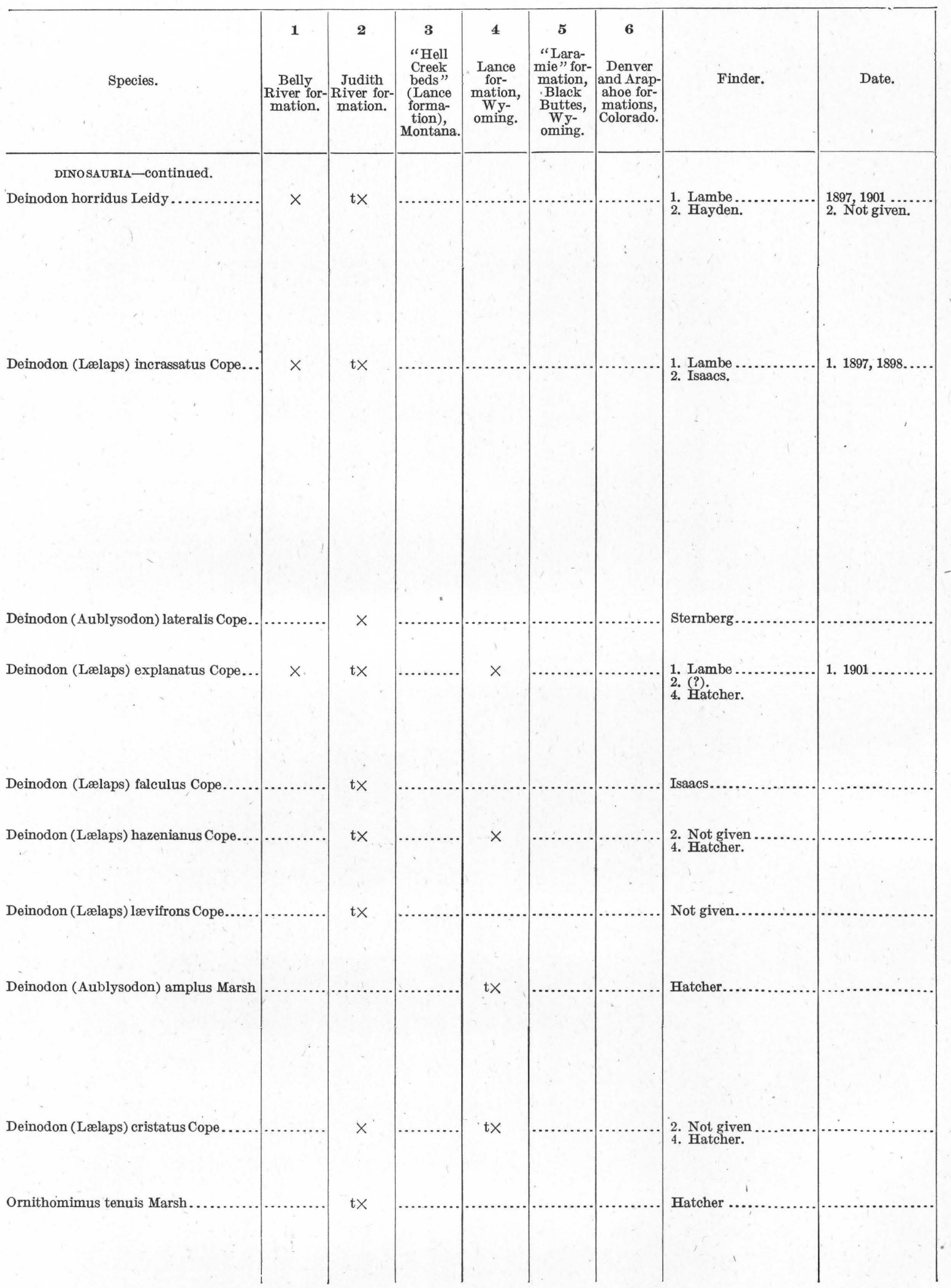


("Hell Creek beds" and "Ceratops beds"), and Denver and Arapahoe formations-Continued.

\begin{tabular}{|c|c|c|c|}
\hline $\begin{array}{l}\text { Locality and stratigraphic po- } \\
\text { sition as given by the authors } \\
\text { cited. }\end{array}$ & $\begin{array}{l}\text { Material on which determina- } \\
\text { tion is based. }\end{array}$ & Authority and reference. & Remarks. \\
\hline $\begin{array}{l}\text { 1. Belly River series, Red } \\
\text { Deer River, Canada. } \\
\text { 2. Badlands of Judith River, } \\
\text { Mont. }\end{array}$ & $\begin{array}{l}\text { 1. A number of teeth; a few } \\
\text { phalanges and a metatar- } \\
\text { sal are also probably re- } \\
\text { ferred to this species. } \\
\text { t2. A number of teeth. }\end{array}$ & $\begin{array}{l}\text { 1. Lambe, Contr. Canadian } \\
\text { Paleontology, vol. 3, pt. 2, } \\
\text { p. 49, 1902. } \\
\text { 2. Leidy, Acad. Nat. Sci. Phil- } \\
\text { adelphia Proc., vol. 8, p. } \\
\text { 72, 1856. Osborn, Am. } \\
\text { Mus. Nat. Hist. Bull., } \\
\text { vol. 21, p. 261, 1905. }\end{array}$ & $\begin{array}{l}\text { 2. The uncertainty regarding the material on } \\
\text { which Leidy founded the type is shown by } \\
\text { the fact that later (Acad. Nat. Sci. Phila- } \\
\text { delphia Proc. for 1868, p. 198) he referred } \\
\text { part of the teeth to a new genus and species } \\
\text { (Aublysodon mirandus); whereas Lambe } \\
\text { (loc. cit.) says that Leidy's first determi- } \\
\text { nation was correct and that the teeth used } \\
\text { at a later date for the foundation of the } \\
\text { genus Aublysodon are probably the an- } \\
\text { terior teeth of Deinodon. Osborn concurs } \\
\text { in this view. }\end{array}$ \\
\hline $\begin{array}{l}\text { 1. Belly River beds near } \\
\text { mouth of Berry Creek, Red } \\
\text { Deer River. } \\
\text { 2. Judith River beds, Montana. }\end{array}$ & $\begin{array}{l}\text { 1. Separate teeth and terminal } \\
\text { phalanges. } \\
\text { t2. Two teeth of different sizes, } \\
\text { found near each other but } \\
\text { not sufficiently near to } \\
\text { warrant the belief that } \\
\text { they belong to the same } \\
\text { individual. }\end{array}$ & $\begin{array}{l}\text { 1. Lambe, Ottawa Naturalist, } \\
\text { vol. 13, p. } 69 \text {, 1899; Contr. } \\
\text { Canadian Paleontology, } \\
\text { vol. 3, pt. 3, p. 5, 1904. } \\
\text { t2. Cope, Acad. Nat. Sci. Phil- } \\
\text { adelphia Proc., vol. } 28, \text { pp. } \\
\text { 248, 341, 1876. } \\
\text { 1 and 2. Hay, U. S. Nat. Mus. } \\
\text { Proc., vol. 35, p. } 356,1909 .\end{array}$ & $\begin{array}{l}\text { Two skulls from the Edmonton formation of } \\
\text { Knee Hills Creek, Red Deer River, Canada, } \\
\text { were originally described by Cope (Am. } \\
\text { Philos. Soc. Proc., vol. 30, p. 240, 1892) as } \\
\text { Lælaps incrassatus. In 1904 Lambe (Contr. } \\
\text { Canadian Paleontology, vol. 3, pt. 3, pp. } \\
\text { 5-27) bestowed on these specimens the } \\
\text { name Dryptosaurus incrassatus. In } 1905 \\
\text { Osborn (Am. Mus. Nat. Hist. Bull., vol. } \\
21 \text {, p. 265) gave them the name Albertosau- } \\
\text { rus sarcophagus. Whatever the final dis- } \\
\text { position of these specimens it is evident } \\
\text { that they do not belong to Lælaps in- } \\
\text { crassatus. } \\
\text { 2. Hatcher (U. S. Geol. Survey Bull. 257, p. 86, } \\
\text { 1905) says: "These teeth are probably from } \\
\text { near the anterior and posterior extremities } \\
\text { of the series in some representative of } D \text {. } \\
\text { horridus Leidy." }\end{array}$ \\
\hline Fort Union beds, Montana. & Detached teeth. & $\begin{array}{l}\text { Cope, Acad. Nat. Sci. Phila- } \\
\text { delphia Proc., vol. 28, p. } \\
248,1876 \text {. }\end{array}$ & 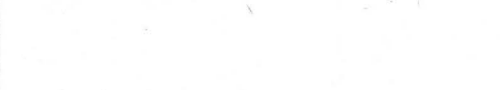 \\
\hline $\begin{array}{l}\text { 1. Belly River series, Red } \\
\text { Deer River, Alberta, Can- } \\
\text { ada. } \\
\text { 2. Fort Union (Judith River) } \\
\text { beds, Montana. } \\
\text { 4. Laramie formation, Wyo- } \\
\text { ming. }\end{array}$ & $\begin{array}{l}\text { 1. One small tooth. } \\
\text { 2. Numerous small teeth. } \\
\text { 4. Teeth similar to those de- } \\
\text { scribed by Cope. }\end{array}$ & $\begin{array}{l}\text { 1. Lambe, Contr. Canadian } \\
\text { Paleontology, vol. 3, pt. 2, } \\
\text { p. } 49,1902 . \\
\text { t2. Cope, Acad. Nat. Sci. Phil- } \\
\text { adelphia Proc., vol. 28, pp. } \\
\text { 249, 344, 1876. } \\
\text { 4. Hatcher, U. S. Geol. Survey } \\
\text { Bull. 257, p. } 86,1905 \text {. }\end{array}$ & \\
\hline $\begin{array}{l}\text { Fort Union (Judith River) } \\
\text { beds, Montana. }\end{array}$ & $\begin{array}{l}\text { Several teeth about half the } \\
\text { size of those of } D \text {. expla- } \\
\text { natus. }\end{array}$ & $\begin{array}{l}\text { t. Cope, Acad. Nat. Sci. Phil- } \\
\text { adelphia Proc., vol. } 28 \text {, pp. } \\
249,344,1876 \text {. }\end{array}$ & $\begin{array}{l}\text { Hatcher (U. S. Geol. Survey Bull. } 257, \text { p. } 86 \text {, } \\
\text { 1905) says that these teeth may represent } \\
\text { anterior teeth of } D \text {. explanatus. }\end{array}$ \\
\hline $\begin{array}{l}\text { 2. Judith River beds, Montana. } \\
\text { 4. Laramie formation. }\end{array}$ & $\begin{array}{l}\text { t2. Several detached teeth } \\
\text { from different localities. } \\
\text { 4. Teeth similar to those de- } \\
\text { scribed by Cope. }\end{array}$ & $\begin{array}{l}\text { t2. Cope, Acad. Nat. Sci. Phil- } \\
\text { adelphia Proc., vol. 28, p. } \\
\text { 343, 1876. } \\
\text { 4. Hatcher, U. S. Geol. Sur- } \\
\text { vey Bull.257, p. } 86,1905 \text {. }\end{array}$ & $\begin{array}{l}\text { 2. Hatcher says that these teeth are common in } \\
\text { the Judith River and Laramie [so-called] } \\
\text { formations. "They appear to pertain to the } \\
\text { anterior dentition of some of these carniv- } \\
\text { orous dinosaurs, probably of } D \text {. horridus." }\end{array}$ \\
\hline Judith River beds, Montana. & Founded on a single tooth. & $\begin{array}{l}\text { t. Cope, Acad. Nat. Sci. Phil- } \\
\text { adelphia Proc., vol. } 28, \text { p. } \\
\text { 344, 1876. }\end{array}$ & $\begin{array}{l}\text { Hatcher (U. S. Geol. Survey Bull. } 257 \text {, p. } 86 \text {, } \\
\text { 1905) says: "It [the tooth which consti- } \\
\text { tutes the type] is distinguished by the ab- } \\
\text { solutely smooth character of the anterior } \\
\text { edge, a character of doubtful value." }\end{array}$ \\
\hline Ceratops beds, Wyoming. & $\begin{array}{l}\text { Founded on detached teeth } \\
\text { similar to those of Aubly- } \\
\text { sodon mirandus, but } \\
\text { smaller. }\end{array}$ & $\begin{array}{l}\text { t. Marsh, Am. Jour. Sci., 3d } \\
\text { ser., vol. } 44 \text {, p. 174, } 1892 \text {. }\end{array}$ & $\begin{array}{l}\text { Hatcher (U. S. Geol. Survey Bull. } 257, \mathrm{p} .84 \text {, } \\
\text { 1905) says that Marsh's A. amplus and } A \text {. } \\
\text { cristatus from the "Ceratops beds" of Mon- } \\
\text { tana and Wyoming are not properly de- } \\
\text { scribed and should be abandoned, that } \\
\text { teeth similar to those figured by Leidy are } \\
\text { common in both the Laramie [so-called] } \\
\text { and Judith River formations, but that they } \\
\text { are not sufficiently characteristic to dis- } \\
\text { tinguish either genera or species. }\end{array}$ \\
\hline $\begin{array}{l}\text { 2. Judith River beds, Montana. } \\
\text { 4. Converse County, Wyo. (?). }\end{array}$ & $\begin{array}{l}\text { 2. Detached teeth. } \\
\text { 4. Teeth. }\end{array}$ & $\begin{array}{l}\text { 2. Cope, Acad. Nat. Sci. Phil- } \\
\text { adelphia Proc., vol. 28, p. } \\
\text { 344, 1876. } \\
\text { t4. Marsh, Am. Jour. Sci., 3d } \\
\text { ser., vol. 44, p. 174, } 1892 \text {. }\end{array}$ & $\begin{array}{l}\text { 2. Hatcher (U. S. Geol. Survey Bull. } 257, \text { p. } 86 \text {, } \\
\text { 1905) says that the teeth resemble those of } \\
\text { Troodon and possibly pertain to that } \\
\text { genus. } \\
\text { 4. See remarks on D. amplus. }\end{array}$ \\
\hline Judith River beds, Montana. & Part of a third metatarsal. & $\begin{array}{l}\text { t. Marsh, Am. Jour. Sci., 3d } \\
\text { ser., vol. 39, pp. 81-86, } 1890 \text {. } \\
\text { Hatcher, U. S. Geol. Sur- } \\
\text { vey Bull. 257, p. } 87,1905 \text {. }\end{array}$ & $\begin{array}{l}\text { Hatcher (loc. cit.) says that the genus Ornitho- } \\
\text { mimus is represented by such meager ma- } \\
\text { terial that as yet it is quite impossible to } \\
\text { determine many of the more important } \\
\text { characters of the genus or to compare the } \\
\text { various species with one another satisfac- } \\
\text { torily. }\end{array}$ \\
\hline
\end{tabular}


TABLE 6.-Geologic distribution of vertebrates in the Belly River, Judith River, Lance

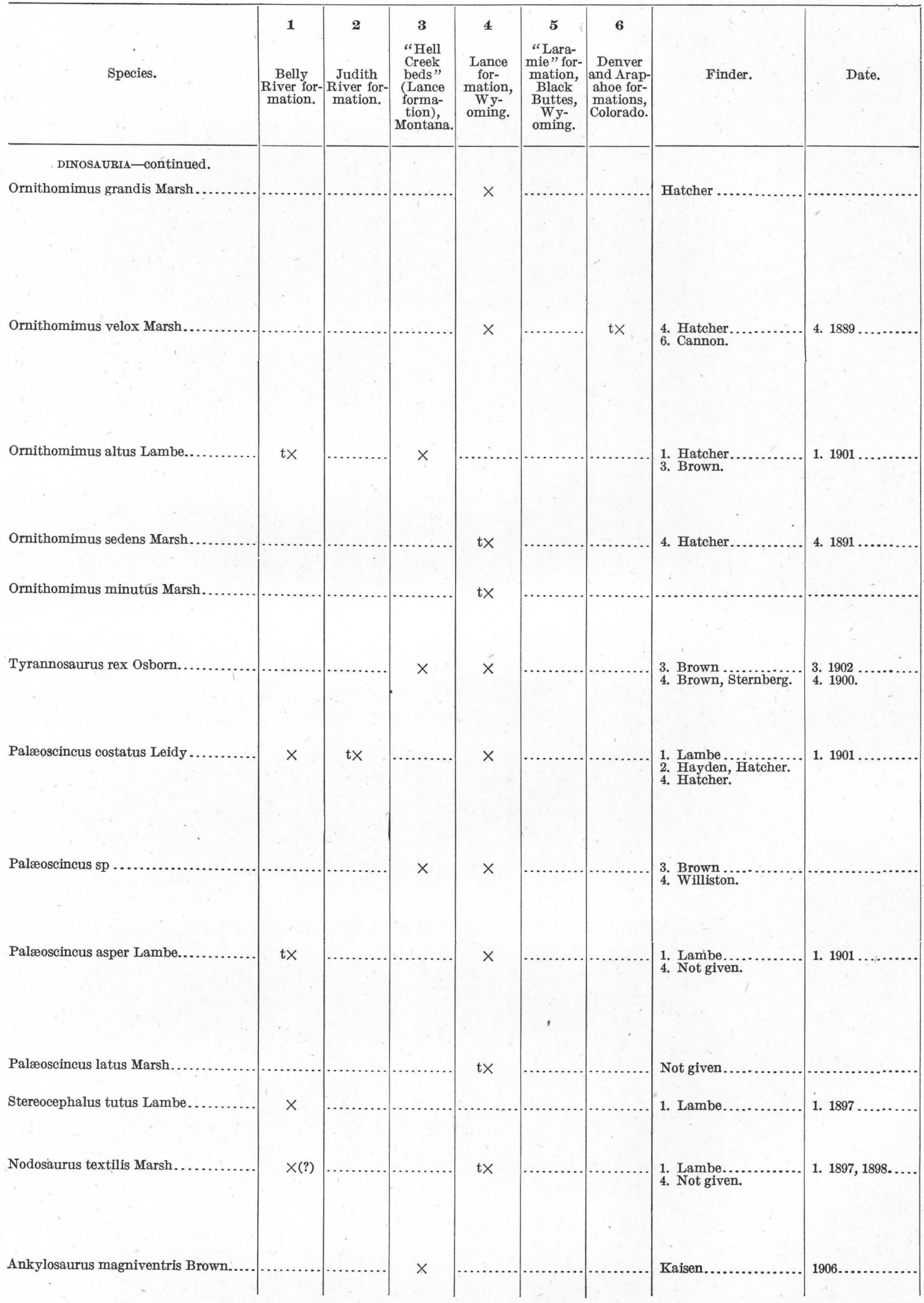


("Hell Creek beds" and"Ceratops beds"), and Denver and Arapahoe formations-Continued.

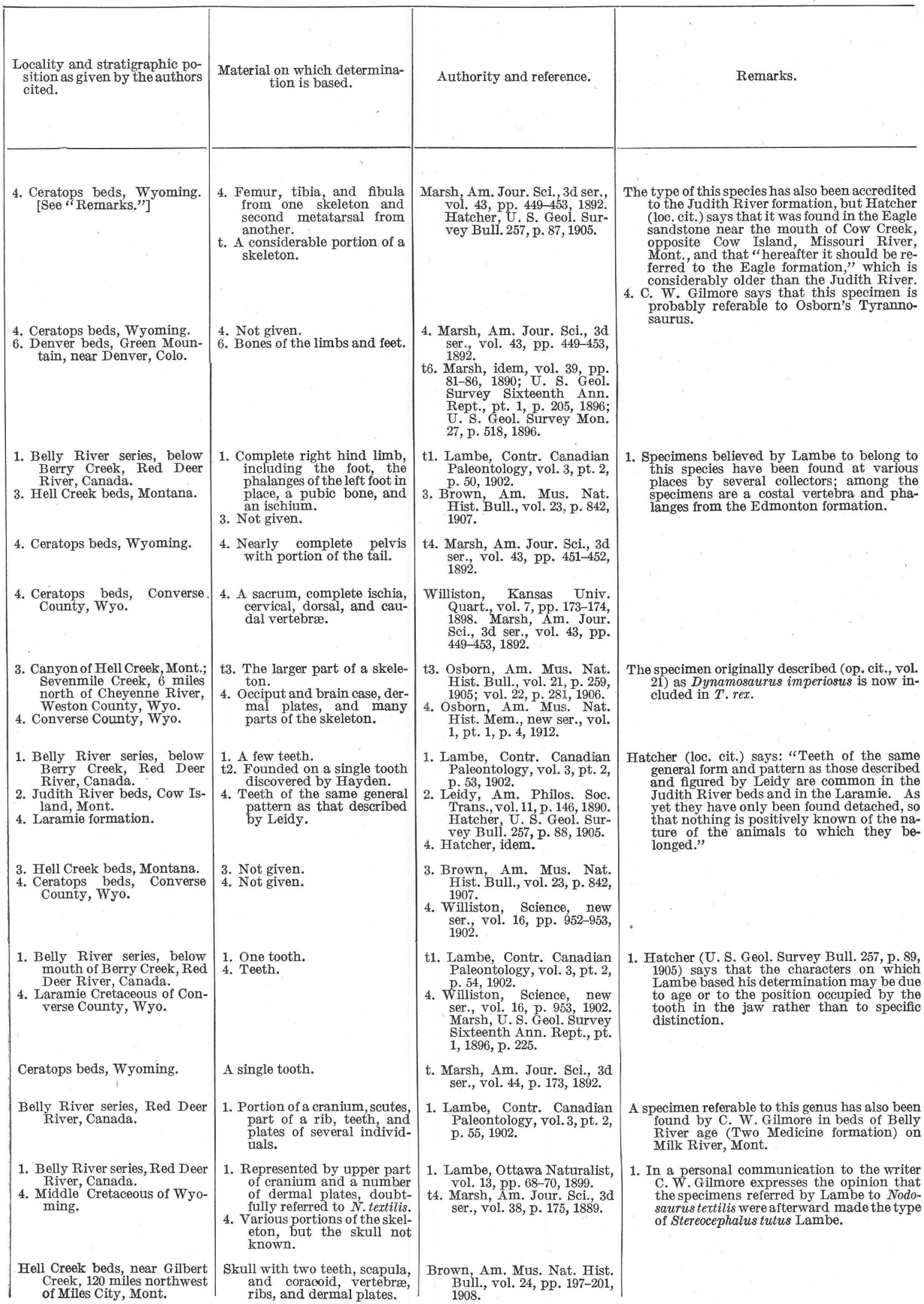


TABLE 6.-Geologic distribution of vertebrates in the Belly River, Judith River, Lance

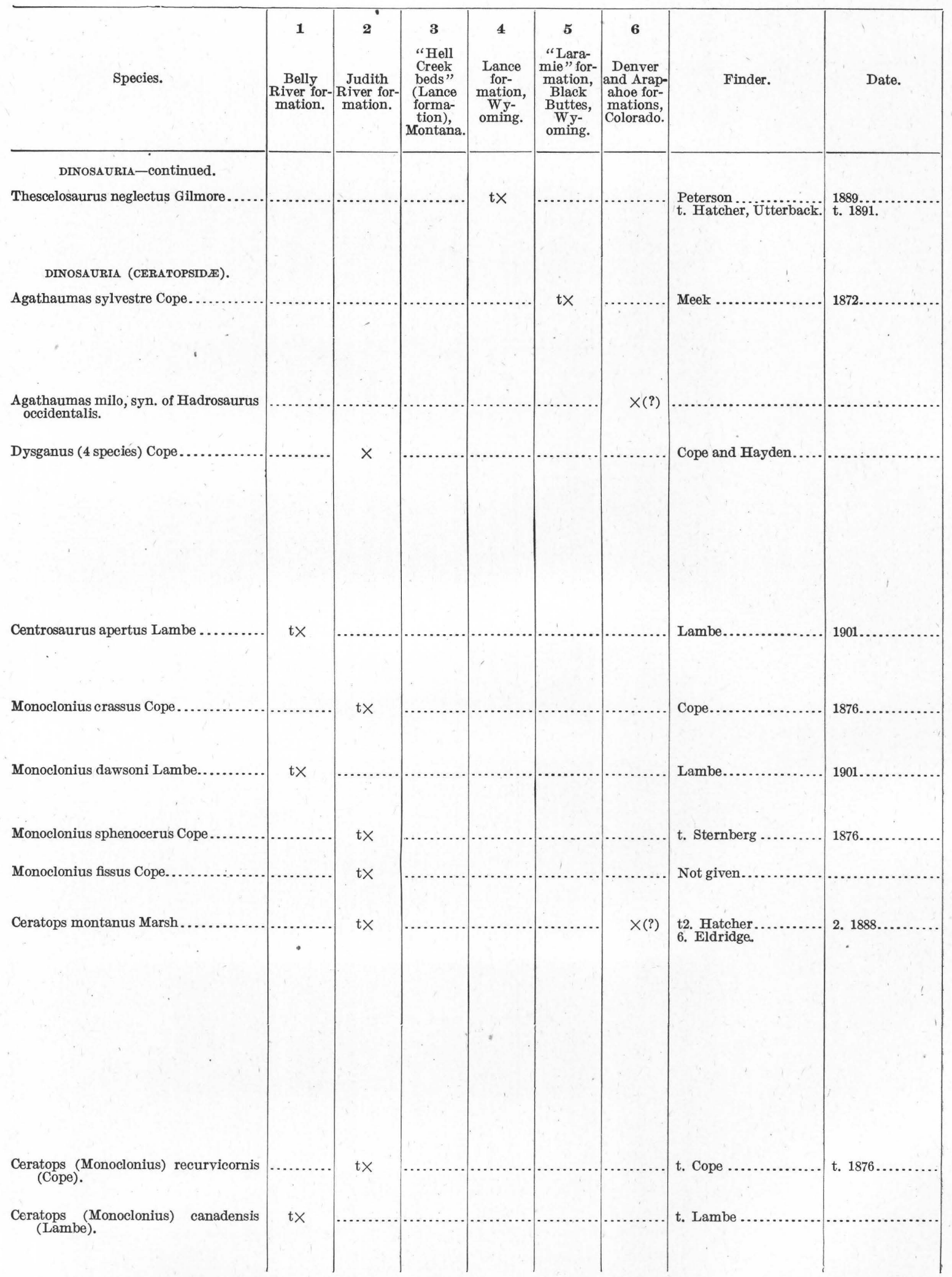


("Hell Creek beds" and "Ceratops beds"), and Denver and Arapahoe formations-Continued.

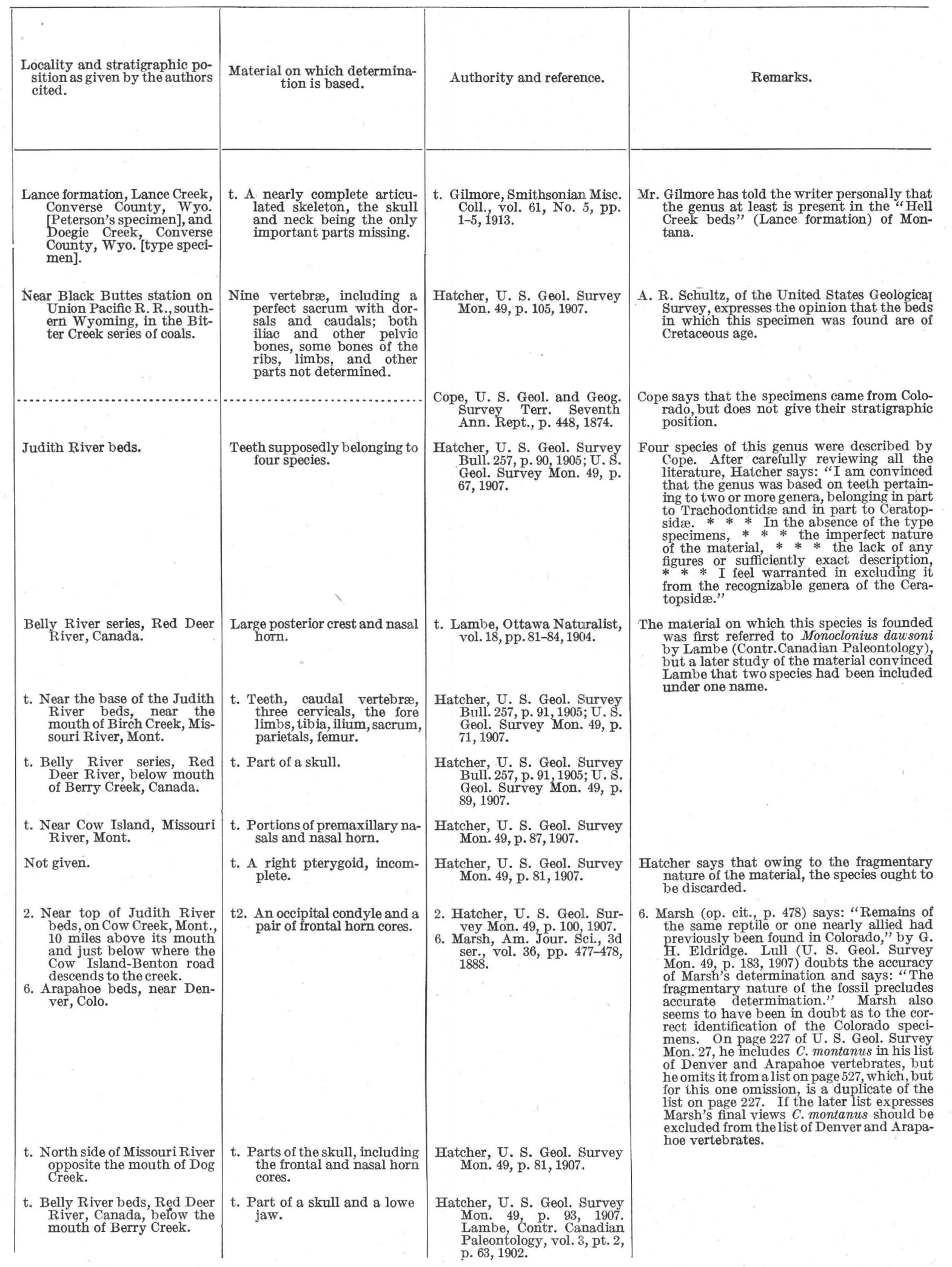


TẢBLE 6.-Geologic distribution of vertebrates in the Belly River, Judith River, Lance

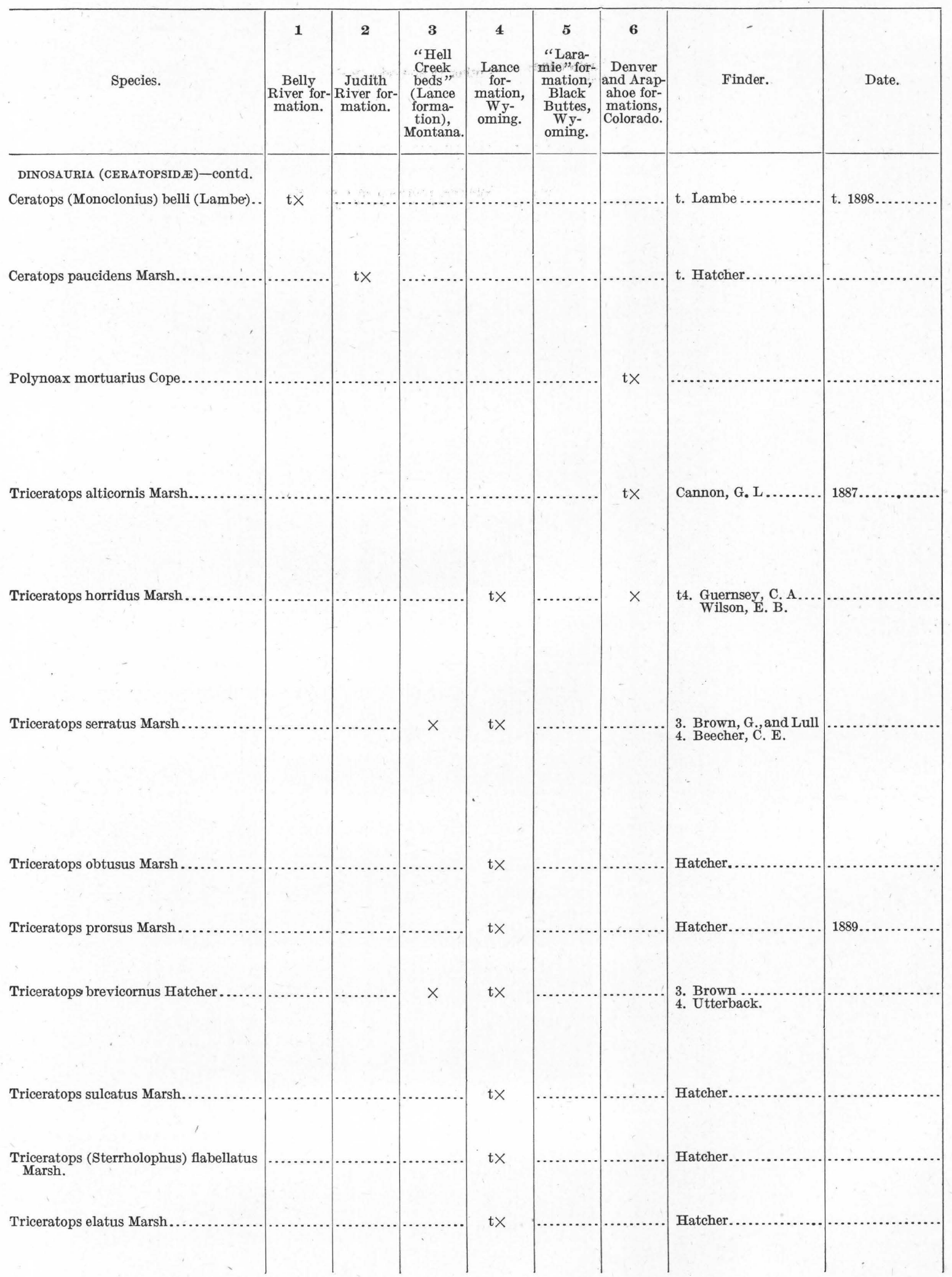


("Hell Creek beds" and "Ceratops beds"), and Denver and Arapahoe formations-Continued.

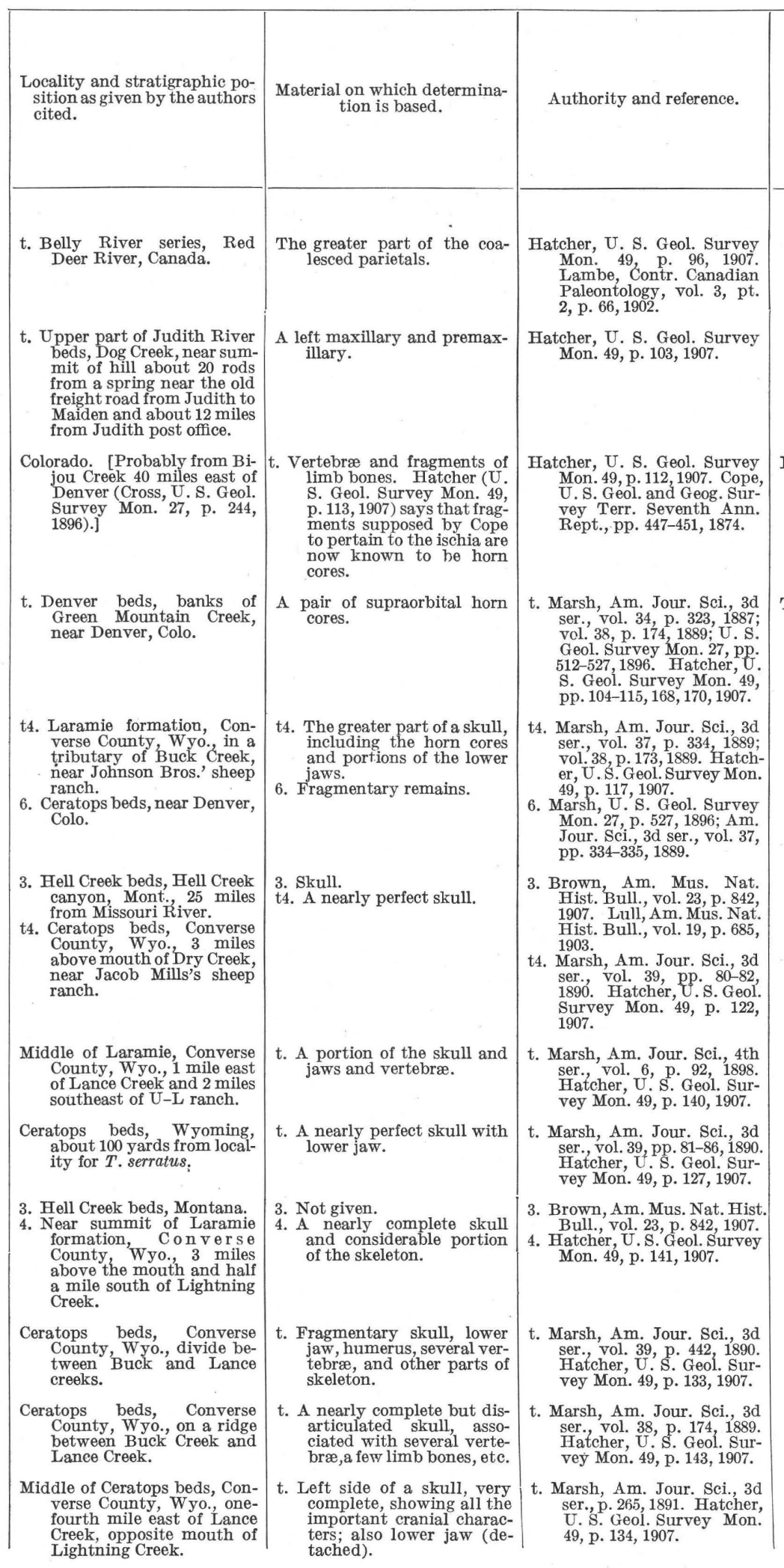

Remarks.

Hatcher (loc. cit.) says: “Cope's description and figures demonstrate $* * *$ the in adequate nature of the material upon which the genus and species were based. The name should be dropped from paleontological literature."

This species was first described as Bison alticornis by Marsh (1887). Later (1889) he ransferred it to the genus Ceratops. Hatcher (op. cit., p. 116) says that th rather than with Ceratops. 
TABLe 6.-Geologic distribution of vertebrates in the Belly River, Judith River, Lance

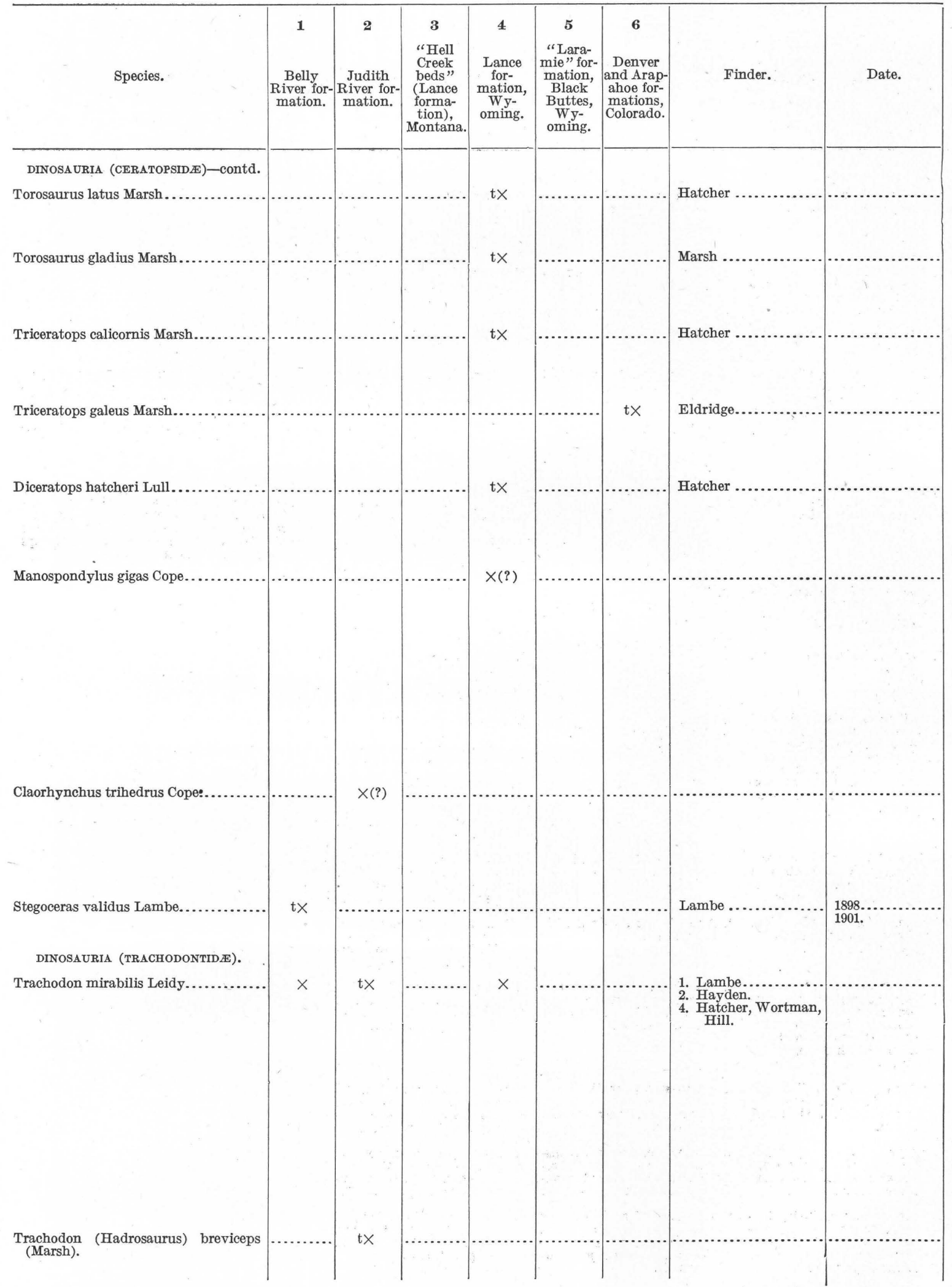


("Hell Creek beds" and "Ceratops beds"), and Denver and Arapahoe formations-Continued.

\begin{tabular}{|c|c|c|c|}
\hline $\begin{array}{l}\text { Locality and stratigraphic po- } \\
\text { sition as given by the authors } \\
\text { cited. }\end{array}$ & $\begin{array}{l}\text { Material on which determina- } \\
\text { tion is based. }\end{array}$ & Authority and reference. & Remarks. \\
\hline & & & ' \\
\hline $\begin{array}{l}\text { Ceratops beds, about } 1 \text { mile } \\
\text { east of } \mathrm{U}-\mathrm{L} \text { ranch, which } \\
\text { is at the junction of Lance } \\
\text { and Dry creeks, Wyo. }\end{array}$ & $\begin{array}{l}\text { t. Skull with lower jaw, } 11 \\
\text { dorsal vertebræ, several } \\
\text { ribs, part of the pelvis, and } \\
\text { other parts of the skeleton. }\end{array}$ & $\begin{array}{l}\text { t. Marsh, Am. Jour. Sci., 4th } \\
\text { ser., vol. 6, p. 92, } 1898 \text {. } \\
\text { Hatcher, U. S. Geol. Sur- } \\
\text { vey Mon. } 49 \text {, p. 138, } 1907 \text {. }\end{array}$ & \\
\hline $\begin{array}{l}\text { Arapahoe beds, near Brighton, } \\
\text { Colo. }\end{array}$ & Nasal horn core. & $\begin{array}{l}\text { Marsh, Am. Jour. Sci., 3d ser., } \\
\text { vol. 38, p. 174, } 1889 . \\
\text { Hatcher, U. S. Geol. Sur- } \\
\text { vey Mon. 49, pp. 132-183. }\end{array}$ & $\begin{array}{l}\text { Hatcher (op. cit., p. 132) says: "The extremely } \\
\text { fragmentary nature of the material on } \\
\text { which the species was based precludes the } \\
\text { possibility of defining it adequately, *** } * \text { } \\
\text { The species should be abandoned." }\end{array}$ \\
\hline $\begin{array}{l}\text { Ceratops beds, Converse } \\
\text { County, Wyo., } 35 \text { miles } \\
\text { southwest of the mouth of } \\
\text { Lightning Creek. }\end{array}$ & $\begin{array}{l}\text { t. A skull without the lower } \\
\text { jaw. }\end{array}$ & $\begin{array}{l}\text { Lull, U. S. Geol. Survey Mon. } \\
\text { 49, p. 149, } 1907 . \\
\text { t. Hatcher, Am. Jour. Sci., } \\
\text { 4th ser., vol. 20, p. } 41 \overline{\text {, }} \\
\text { 1905. }\end{array}$ & \\
\hline $\begin{array}{l}\text { Ceratops beds, Converse } \\
\text { County, Wyo., on the } \\
\text { north side of Lightning } \\
\text { Creek, about } 2 \text { miles above } \\
\text { the mouth of the stream. }\end{array}$ & $\begin{array}{l}\text { A skull without lower jaw. } \\
\text { Posterior part of parietals, } \\
\text { summits of horn cores, and } \\
\text { parts of maxillaries are } \\
\text { wanting. }\end{array}$ & $\begin{array}{l}\text { t. Marsh, Am. Jour. Sci., 3d } \\
\text { ser., vol. 42, p. 266, } 1891 \text {. } \\
\text { Hatcher, U. S. Geol. Survey } \\
\text { Mon. } 49, \text { p. } 150,1907 \text {. }\end{array}$ & \\
\hline $\begin{array}{l}\text { Laramie of Converse County, } \\
\text { Wyo., on low divide be- } \\
\text { tween Lightning and Cow } \\
\text { creeks, about } 1 \text { mile dis- } \\
\text { tant from the mouths of } \\
\text { these streams. }\end{array}$ & $\begin{array}{l}\text { A nearly complete parietal, } \\
\text { left squamosal, horn cores, } \\
\text { one epijugal, the occipital } \\
\text { condyle, and other parts } \\
\text { of the skeleton. }\end{array}$ & $\begin{array}{l}\text { t. Marsh, Am. Jour. Sci., 3d } \\
\text { ser., vol. } 42 \text {, pp. } 266-267 \text {, } \\
\text { 1891. } \\
\text { Hatcher, U. S. Geol. Survey } \\
\text { Mon. } 49 \text {, p. 152, 1907. }\end{array}$ & 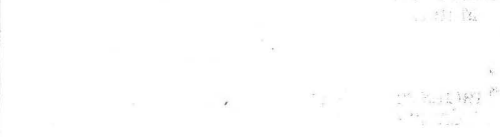 \\
\hline $\begin{array}{l}\text { Laramie of South Dakota; } \\
\text { probably also from the } \\
\text { Laramie of Converse } \\
\text { County, Wyo. } \\
\text { t. Laramie of South Dakota. }\end{array}$ & $\begin{array}{l}\text { t. Two dorsal vertebræ, of } \\
\text { which only one can be } \\
\text { found now. }\end{array}$ & $\begin{array}{l}\text { Hatcher, U. S. Geol. Survey } \\
\text { Mon. 49, p. 113, 1907; U. S. } \\
\text { Geol. Survey Bull. 257, p. } \\
\text { 96, } 1905 . \\
\text { t. Cope, Am. Naturalist, vol. } \\
\text { 26, p. 757, 1892. }\end{array}$ & 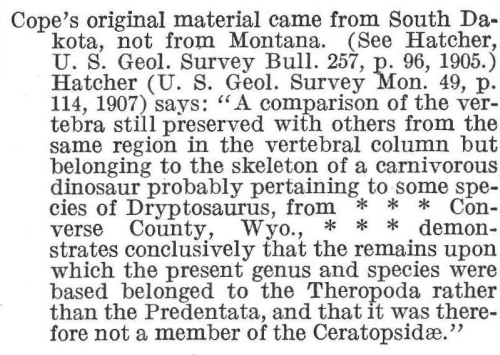 \\
\hline $\begin{array}{l}\text { Laramie. [No locality was } \\
\text { given by Cope; Hatcher } \\
\text { thinks it came from South } \\
\text { Dakota, but O b or n } \\
\text { (Contr. Canadian Paleon- } \\
\text { tology, vol. 3, pt. } 2 \text {, p. } 15 \text {, } \\
\text { 1902) has included it in his } \\
\text { Montana list.] }\end{array}$ & $\begin{array}{l}\text { t. A rostral and predentary, } \\
\text { both of which are now lost. }\end{array}$ & $\begin{array}{l}\text { Hatcher, U. S. Geol. Survey } \\
\text { Mon.49, p. 114, 1907. }\end{array}$ & $\begin{array}{l}\text { This species is regarded by Hatcher (op. cit.) as } \\
\text { belonging to the Trachodontidæ rather } \\
\text { than to the Ceratopsidæ, but he says that } \\
\text { in the absence of the type material the } \\
\text { affinities can not be established with cer- } \\
\text { tainty. }\end{array}$ \\
\hline $\begin{array}{l}\text { Belly River series, Red Deer } \\
\text { River, Canada. }\end{array}$ & $\begin{array}{l}\text { Founded on two cranial frag- } \\
\text { ments, probably belonging } \\
\text { to two species. }\end{array}$ & $\begin{array}{l}\text { Hatcher, U. S. Geol. Survey } \\
\text { Mon. 49, p. 98, 1907. } \\
\text { Lambe, Contr. Canadian } \\
\text { Paleontology, vol. } 3 \text {, pt. } 2 \text {, } \\
\text { p. } 68,1902 .\end{array}$ & $\begin{array}{l}\text { Hatcher does not include this species in the } \\
\text { Ceratopsidæ. He thinks that it belongs to } \\
\text { a hitherto unknown reptile, and that it will } \\
\text { probably be found to belong to another } \\
\text { order. }\end{array}$ \\
\hline $\begin{array}{l}\text { 1. Belly River series, near } \\
\text { mouth of Berry Creek, Red } \\
\text { Deer River, Canada. } \\
\text { t2. Badlands of Judith River, } \\
\text { Mont. } \\
\text { 4. Converse County, Wyo. }\end{array}$ & $\begin{array}{l}\text { 1. Numerous maxillæ and } \\
\text { rami, some with teeth well } \\
\text { preserved,as well as a large } \\
\text { number of principal bones. } \\
\text { t2. "Specimens of teeth, gen- } \\
\text { erally much worn and in a } \\
\text { fragmentary condition." } \\
\text { 4. By Wortman and Hill, a } \\
\text { skeleton; by Hatcher, a } \\
\text { skeleton. }\end{array}$ & $\begin{array}{l}\text { 1. Lambe, Ottawa Naturalist, } \\
\text { vol. 13, p. 69, } 1899 . \\
\text { t2. Leidy, Acad. Nat. Sci. } \\
\text { Philadelphia Proc., vol. 8, } \\
\text { p. } 72,1856 \text {. Hatcher, U. S. } \\
\text { Geol. Survey Bull. 257, p. } \\
\text { 96, } 1905 . \\
\text { 4. Hatcher, Carnegie Mus. An- } \\
\text { nals, vol. 1, pp. 382, 386, } \\
\text { 1902; Science, new ser., } \\
\text { vol. 12, p. } 719,1900 .\end{array}$ & $\begin{array}{l}\text { 1. Lambe (loc. cit.) states that remains of this } \\
\text { species have also been collected by F. G. } \\
\text { McConnell from the Laramie [so-called] at } \\
\text { Scabby Butte, on Red Deer River. } \\
\text { 2. Hatcher (loc. cit.) says: "It is scarcely pos- } \\
\text { sible to identify the various species of this } \\
\text { genus or the genera of the family [Tracho- } \\
\text { dontidær from the teeth alone." } \\
\text { 4. In Science, vol. 12, Hatcher refers to finding } \\
\text { a skeleton of Claosaurus of which he de- } \\
\text { scribes the dermal covering but does not } \\
\text { give the specific name. In the Carnegie } \\
\text { Mus. Annals, vol. 1, he credits Cope with } \\
\text { having first described this covering from } \\
\text { the same species, Trachodon (Diclonius) } \\
\text { mirabilis. The assumption is therefore } \\
\text { justified that Hatcher's Claosaurus from } \\
\text { Converse County, Wyo., is synonymous } \\
\text { with T. mirabitis. }\end{array}$ \\
\hline t. Laramie [Judith River $\mathrm{f}$ & Part of a right maxillary with & t. Marsh, Am. Jour. Sci., 3d & Hatcher (loc. cit.) says that the teeth resemble \\
\hline
\end{tabular}
mation], Bearpaw Mountains, Mont. teeth well preserved. $\quad$ ser., vol. 37, p. 335, 1889. Hatcher, U. S. Geol. Sur-
vey Bull. 257 , p. 97,1905 . closely those of T. selwyni Lambe. 
TABLE 6.-Geologic distribution of vertebrates in the Belly River, Judith River, Lance

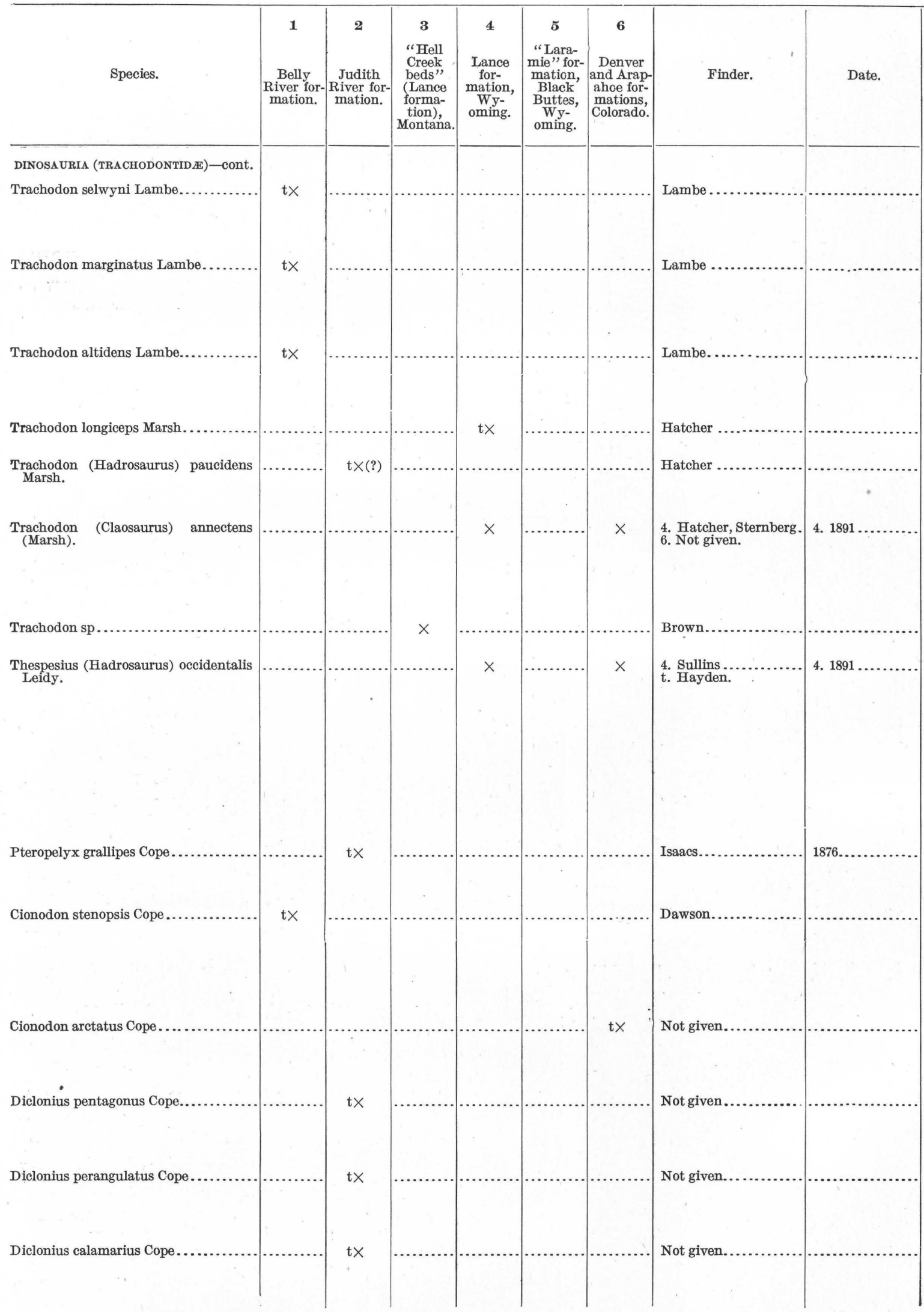


("Hell Creek beds" and "Ceratops beds"), and Denver and Arapahoe formations-Continued.

\begin{tabular}{|c|c|c|c|}
\hline $\begin{array}{l}\text { Locality and stratigraphic po- } \\
\text { sition as given by the authors } \\
\text { cited. }\end{array}$ & $\begin{array}{l}\text { Material on which determina- } \\
\text { tion is based. }\end{array}$ & Authority and reference. & Remarks. \\
\hline $\begin{array}{l}\text { Belly River series. [Location } \\
\text { not given.] }\end{array}$ & $\begin{array}{l}\text { Founded on teeth differing } \\
\text { from those of } T \text {. mirabilis } \\
\text { by being rounded oval } \\
\text { above instead of terminat- } \\
\text { ing in a point. }\end{array}$ & $\begin{array}{l}\text { t. Lambe, Contr. Canadian } \\
\text { Paleontology, vol. 3, pt. 2, } \\
\text { p. 69, 1902. Hatcher, U. S. } \\
\text { Geol. Survey Bull. 257, p. } \\
\text { 97, } 1905 .\end{array}$ & $\begin{array}{l}\text { Hatcher (loc. cit.) says that this species may be } \\
\text { a synonym of } T \text {. breviceps. }\end{array}$ \\
\hline $\begin{array}{l}\text { Belly River series, Red Deer } \\
\text { River district, Canada. }\end{array}$ & $\begin{array}{l}\text { Humerus, radius, ulna of left } \\
\text { fore limb, a metatarsal and } \\
\text { phalanges, fragments of } \\
\text { teeth of one individual, } \\
\text { and various parts of the } \\
\text { skeleton found dissociated. }\end{array}$ & $\begin{array}{l}\text { t. Lambe, Contr. Canadian } \\
\text { Paleontology, vol. 3, pt. 2, } \\
\text { p. 71, 1902. Hatcher, U. S. } \\
\text { Geol. Survey Bull. 257, p. } \\
\text { 97, } 1905 .\end{array}$ & $\begin{array}{l}\text { Hatcher (loc. cit.) says that this species is based } \\
\text { on material pertaining to different species, } \\
\text { genera, families, and even orders. }\end{array}$ \\
\hline $\begin{array}{l}\text { Belly River series, Red Deer } \\
\text { River district, Canada. }\end{array}$ & A left maxilla with the teeth. & $\begin{array}{l}\text { t. Lambe, Contr. Canadian } \\
\text { Paleontology, vol. 3, pt. 2, } \\
\text { p. 76, 1902. Hatcher, U. S. } \\
\text { Geol. Survey Bull. 257, p. } \\
\text { 98, } 1905 .\end{array}$ & \\
\hline Laramie of Wyoming. & $\begin{array}{l}\text { A nearly perfect right dentary } \\
\text { bone. }\end{array}$ & $\begin{array}{l}\text { Marsh, Am. Jour. Sci., } 3 \text { d ser., } \\
\text { vol. } 39 \text {, pp. } 422-424,1890 .\end{array}$ & \\
\hline Laramie of Montana. & $\begin{array}{l}\text { A left maxillary nearly com- } \\
\text { plete and other portions of } \\
\text { the skull. }\end{array}$ & $\begin{array}{l}\text { t. Marsh, Am. Jour. Sci., 3d } \\
\text { ser., vol. 37, p. 336, 1889. }\end{array}$ & $\begin{array}{l}\text { The only locality given is Montana. The fossils } \\
\text { may have come from either the Judith } \\
\text { River or the Lance formation, as Marsh } \\
\text { referred to both formations as the Laramie. }\end{array}$ \\
\hline $\begin{array}{l}\text { 4. Laramie of Converse County, } \\
\text { Wyo. } \\
\text { 6. Ceratops beds, near Denver, } \\
\text { Colo. }\end{array}$ & $\begin{array}{l}\text { 4. By Hatcher-a nearly com- } \\
\text { plete skeleton. } \\
\text { By Sternberg-a nearly com- } \\
\text { plete skeleton. } \\
\text { Not given. }\end{array}$ & $\begin{array}{l}\text { 4. Marsh, Am. Jour. Sci., 3d } \\
\text { ser., vol. 43, pp. 449-453, } \\
\text { 1892. Osborn, Science, } \\
\text { new ser., vol. 29, p. 793, } \\
1909 . \\
\text { 6. Marsh, U. S. Geol. Survey } \\
\text { Mon. 27, p. 227, 1896. }\end{array}$ & \\
\hline Hell Creek beds, Montana. & Not given. & $\begin{array}{l}\text { Brown, Am. Mus. Nat. Hist. } \\
\text { Bull., vol. 23, p. } 842,1907 \text {. }\end{array}$ & \\
\hline $\begin{array}{l}\text { 4. Laramie of Wyoming. } \\
\text { 6. Ceratops near Denver, Colo. } \\
\text { t. Grand River, Nebr. (N. } \\
\text { Dak.) }\end{array}$ & $\begin{array}{l}\text { 4. A nearly complete skull and } \\
\text { skeleton. } \\
\text { 6. Not given. }\end{array}$ & $\begin{array}{l}\text { 4. Marsh, Am. Jour. Sci., 3d } \\
\text { ser., vol. 43, pp. 449-453, } \\
\text { 1892. Hatcher, Am. Jour. } \\
\text { Sci., 3d ser., vol. 45, p. 143, } \\
\text { 1893. } \\
\text { 6. Cope, U. S. Geol. and Geog. } \\
\text { Survey Terr. Seventh } \\
\text { Ann. Rept., pp. 432-466, } \\
\text { 1874. Marsh, U. S. Geol. } \\
\text { Survey Mon. 27, p. 527, } \\
\text { 1896. } \\
\text { t. Leidy, Acad. Nat. Sci. Phil- } \\
\text { adelphia Proc., vol. 8, p. } \\
\text { 311, 1856. }\end{array}$ & $\begin{array}{l}\text { 4. Marsh described the Wyoming and Colorado } \\
\text { specimens as Claosaurus annectens. }\end{array}$ \\
\hline $\begin{array}{l}\text { t. Judith River beds, near } \\
\text { Cow Island, Mont. }\end{array}$ & $\begin{array}{l}\text { A considerable portion of a } \\
\text { skeleton without skull or } \\
\text { teeth. }\end{array}$ & $\begin{array}{l}\text { t. Cope, Am. Naturalist, vol. } \\
23 \text {, p. 904, 1889. Hatcher, } \\
\text { U. S. Geol. Survey Bull. } \\
257 \text {, p. } 98,1905 \text {. }\end{array}$ & \\
\hline $\begin{array}{l}\text { t. Fort Union (?) beds, near } \\
\text { Milk River near latitude } \\
49^{\circ} \text { and between longitudes } \\
112^{\circ} \text { and } 113^{\circ} \text {. }\end{array}$ & t. Maxillary and teeth. & $\begin{array}{l}\text { Cope, Acad. Nat. Sci. Phila- } \\
\text { delphia Proc., vol. 28, p. 9, } \\
\text { 1876. } \\
\text { t. Dawson, British North } \\
\text { America Boundary Comm. } \\
\text { Rept., p. 130, 1875. Hatch- } \\
\text { er,U. S. Geol. Survey Bull. } \\
\text { 257, p. 99, 1905. }\end{array}$ & $\begin{array}{l}\text { Eugene Stebinger, of the United States Geologi- } \\
\text { cal Survey, who has recently mapped this } \\
\text { area, says that the formation is undoubt- } \\
\text { edly of Belly River age. }\end{array}$ \\
\hline Colorado. & $\begin{array}{l}\text { A tooth, two dorsal vertebræ, } \\
\text { distal end of a femur with } \\
\text { the condyles well pre- } \\
\text { served. }\end{array}$ & $\begin{array}{l}\text { t. Cope, U. S. Geol. Survey } \\
\text { Terr. Rept., vol. 2, pp. 57- } \\
62 \text {, 1875. Hatcher, Car- } \\
\text { negie Mus. Annals, vol. 1, } \\
\text { p. } 381,1902 \text {. }\end{array}$ & \\
\hline $\begin{array}{l}\text { Fort Union beds [Judith River } \\
\text { formation], Montana. }\end{array}$ & Detached teeth. & $\begin{array}{l}\text { t. Cope, Acad. Nat. Sci. Phil- } \\
\text { adelphia Proc., vol. 28, p. } \\
\text { 253, 1876. Hatcher, U. S. } \\
\text { Geol Survey Bull. 257, p. } \\
\text { 99, 1905. }\end{array}$ & $\begin{array}{l}\text { Concerning this and the next two species, } \\
\text { Hatcher (loc. cit.) says the genus is gen- } \\
\text { erally considered as a synonym of Tracho- } \\
\text { don. In the absence of any figures it is } \\
\text { doubtful if any of the species are identi- }\end{array}$ \\
\hline $\begin{array}{l}\text { Fort Union beds [Judith River } \\
\text { formation], Montana. }\end{array}$ & Detached teeth. & $\begin{array}{l}\text { t. Cope, Acad. Nat. Sci. Phil- } \\
\text { adelphia Proc., vol. 28, p. } \\
\text { 254, 1876. Hatcher, U. S. } \\
\text { Geol. Survey Bull. } 257, \text { p. } \\
\text { 99, 1905. }\end{array}$ & $\begin{array}{l}\text { these are no longer determinable in the } \\
\text { Cope collection, it would not be amiss to } \\
\text { drop the specific names referred to this } \\
\text { genus. }\end{array}$ \\
\hline $\begin{array}{l}\text { Fort Union beds [Judith River } \\
\text { formation], Montana. }\end{array}$ & Detached teeth. & $\begin{array}{l}\text { t. Cope, Acad. Nat. Sci. Phil- } \\
\text { adelphia Proc., vol. } 28, \text { p. } \\
\text { 255, } 1876 \text {. Hatcher, U. S. } \\
\text { Geol. Survey Bull. } 257, \text { p. } \\
\text { 99, } 1905 .\end{array}$ & \\
\hline
\end{tabular}


TABLE 6.-Geologic distribution of vertebrates in the Belly River, Judith River, Lance

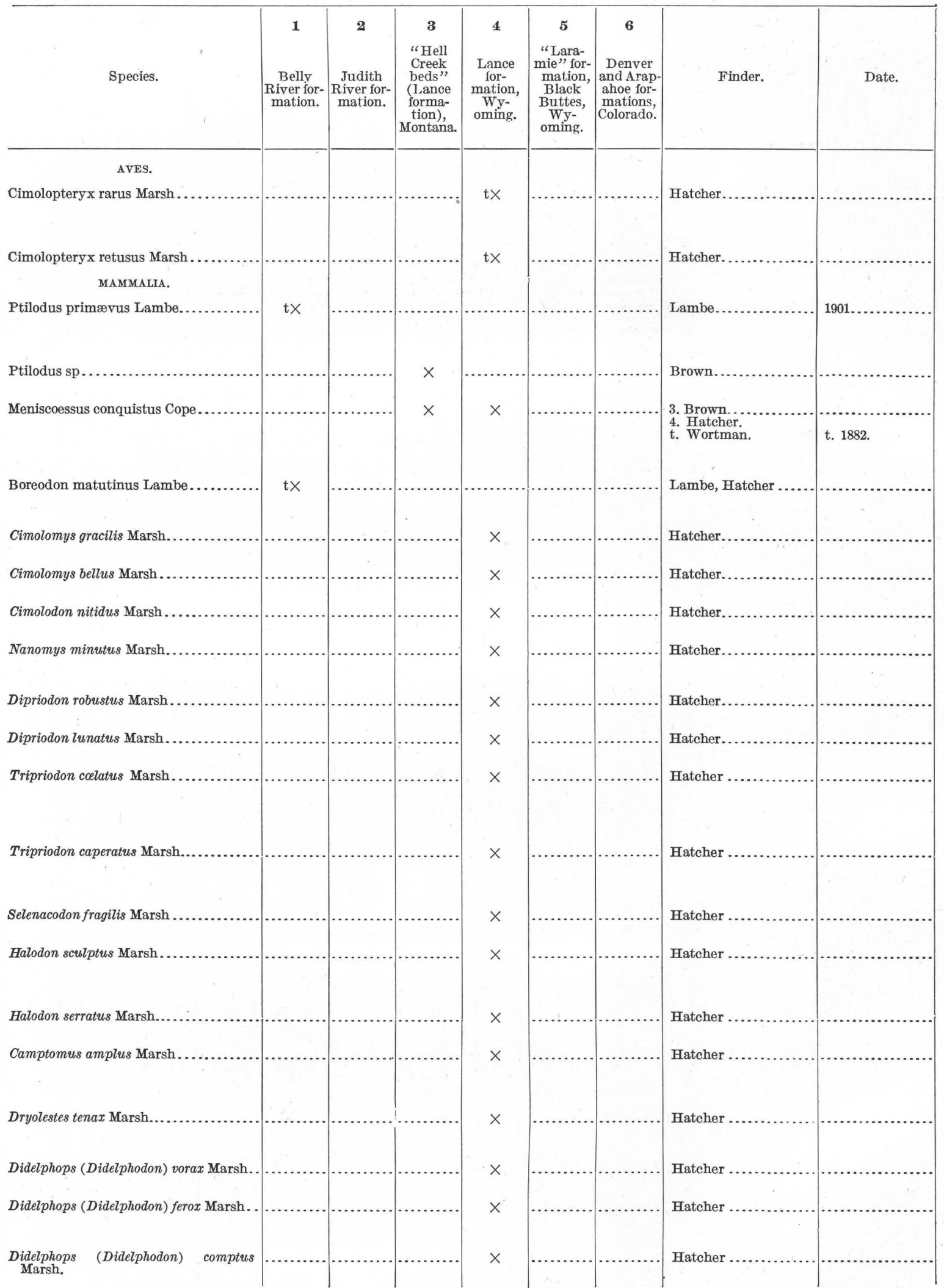


("Hell Creek beds" and "Ceratops beds"), and Denver and A rapahoe formations-Continued.

\begin{tabular}{|c|c|c|c|}
\hline $\begin{array}{l}\text { Locality and stratigraphic po- } \\
\text { sition as given by the authors } \\
\text { cited. }\end{array}$ & $\begin{array}{l}\text { Material on which determina- } \\
\text { tion is based. }\end{array}$ & Authority and reference. & Remarks. \\
\hline Laramie of Wyoming. & A coracoid bone. & $\begin{array}{l}\text { t. Marsh, Am. Jour. Sci., 3d } \\
\text { ser., vol. 38, p. } 83 \text { (foot- } \\
\text { note), 1889; vol. } 44 \text {, p. } 175 \text {, } \\
\text { 1892. }\end{array}$ & \\
\hline Laramie of Wyoming. & A left coracoid. & $\begin{array}{l}\text { t. Marsh, Am. Jour. Sci., 3d } \\
\text { ser., vol. 44, p. 175, 1892. }\end{array}$ & \\
\hline $\begin{array}{l}\text { Belly River series, Red Deer } \\
\text { River, Canada. }\end{array}$ & $\begin{array}{l}\text { An imperfect right mandible } \\
\text { and ramus with fourth } \\
\text { premolar and first molar } \\
\text { attached. }\end{array}$ & $\begin{array}{l}\text { Lambe, Contr. Canadian Pa- } \\
\text { leontology, vol. } 3 \text {, pt. } 2 \text {, p. } \\
79,1902 .\end{array}$ & \\
\hline Hell Creek beds, Montana. & Not given. & $\begin{array}{l}\text { Brown, Am. Mus. Nat. Hist. } \\
\text { Bull., vol. 23, p. } 842,1907 \text {. }\end{array}$ & \\
\hline $\begin{array}{l}\text { 3. Hell Creek beds, Montana. } \\
\text { 4. Laramie formation. Lo- } \\
\text { cality not given. } \\
\text { t. Laramie of South Dakota. }\end{array}$ & $\begin{array}{l}\text { 3. Not given. } \\
\text { t. Two molars and a distal ex- } \\
\text { tremity of a humerus. }\end{array}$ & $\begin{array}{l}\text { 3. Brown, Am. Mus. Nat. } \\
\text { Hist. Bull., vol. } 23, \text { p. } 842 \text {, } \\
\text { 1907. Am. Naturalist, vol. } \\
\text { 4. Cope, Am. Natu. } \\
\text { 16, p. } 830,1882 \text {. }\end{array}$ & \\
\hline $\begin{array}{l}\text { Belly River series, Red Deer } \\
\text { River, Canada. }\end{array}$ & $\begin{array}{l}\text { By Lambe, a single tooth. } \\
\text { By Hatcher, a jaw. }\end{array}$ & $\begin{array}{l}\text { Lambe, Contr. Canadian Pa- } \\
\text { leontology, vol. } 3 \text {, pt. } 2 \text {, p. } \\
79,1902 .\end{array}$ & \\
\hline Laramie of Wyoming. & An upper molar. & $\begin{array}{l}\text { Marsh, Am. Jour. Sci., } 3 \mathrm{~d} \text { ser., } \\
\text { vol. } 38, \text { pp. } 81-90,1889 .\end{array}$ & $\begin{array}{l}\text { In Science, new ser., vol. } 12, \text { p. } 719,1900 \text {, Hatcher } \\
\text { says that all the mammals obtained by } \\
\text { him under the direction of Marsh came }\end{array}$ \\
\hline Laramie of Wyoming. & An upper molar. & $\begin{array}{l}\text { Marsh, Am. Jour. Sci., 3d ser., } \\
\text { vol. } 38, \text { pp. } 81-90,1889 .\end{array}$ & $\begin{array}{l}\text { him under the direction of Marsh came } \\
\text { from Converse County, Wyo. Hence all } \\
\text { the succeeding species are from that gen- } \\
\text { eral locality. }\end{array}$ \\
\hline Laramie of Wyoming. & An upper molar. & $\begin{array}{l}\text { Marsh, Am. Jour. Sci., } 3 \mathrm{~d} \text { ser., } \\
\text { vol. } 38, \text { pp. } 81-90,1889 .\end{array}$ & $\begin{array}{l}\text { The } 17 \text { genera and } 28 \text { species whose } \\
\text { names are printed in italie in the list } \\
\text { (taken from Marsh) have, according to Os- }\end{array}$ \\
\hline Laramie of Wyoming. & $\begin{array}{l}\text { A number of very minute } \\
\text { teeth, of which a single } \\
\text { tooth is taken as a type. }\end{array}$ & $\begin{array}{l}\text { Marsh, Am. Jour. Sci., 3d ser., } \\
\text { vol. } 38, \text { pp. } 81-90,1889 .\end{array}$ & $\begin{array}{l}\text { born (Am. Naturalist, vol. } 25 \text {, p. } 609,1891 \text { ), } \\
\text { been reduced to “ four or five genera, one of } \\
\text { which can now be well defined (Meniscoes- } \\
\text { sus), while the remainder are probably }\end{array}$ \\
\hline Laramie of Wyoming. & A left upper molar. & $\begin{array}{l}\text { Marsh, Am. Jour. Sci., } 3 \mathrm{~d} \text { ser., } \\
\text { vol. } 38 \text {, pp. } 81-90,1889 .\end{array}$ & $\begin{array}{l}\text { sus), while the remainder are probably } \\
\text { distinct genera, which we may be able to } \\
\text { define by the acquisition of more material } \\
\text { (Cimolomys, Didelphops, and Cimolestes). }\end{array}$ \\
\hline Laramie of Wyoming. & A first or second molar. & $\begin{array}{l}\text { Marsh, Am. Jour. Sci., 3d ser., } \\
\text { vol. } 38, \text { pp. } 81-90,1889 .\end{array}$ & $\begin{array}{l}\text { There is no question that the majority of } \\
\text { the remaining generic names are syno- } \\
\text { nyms, although it is quite possible that }\end{array}$ \\
\hline Laramie of Wyoming. & $\begin{array}{l}\text { An upper molar. Several } \\
\text { lower molars were found } \\
\text { with the type, but the as- } \\
\text { sociation may be acciden- } \\
\text { tal. }\end{array}$ & $\begin{array}{l}\text { Marsh, Am. Jour. Sci., } 3 \text { d ser., } \\
\text { vol. } 38 \text {, pp. } 81-90,1889 .\end{array}$ & $\begin{array}{l}\text { nyms, although it is quite possible that } \\
\text { some of the types described, such as Oraco- } \\
\text { don and Pediomys, may be found to repre- } \\
\text { sent distinct or new genera." } \\
\text { The remaining species of the list have } \\
\text { been reviewed by the same writer (Am. Mus. }\end{array}$ \\
\hline Laramie of Wyoming. & $\begin{array}{l}\text { A lower incisor, associated } \\
\text { with other incisors and } \\
\text { other teeth in various } \\
\text { states of preservation. }\end{array}$ & $\begin{array}{l}\text { Marsh, Am. Jour. Sci., 3d ser., } \\
\text { vol. } 38, \text { pp. } 81-90,1889 .\end{array}$ & $\begin{array}{l}\text { Nat. Hist. Bull., vol. 5, pp. } 311-330,1893 \text { ), } \\
\text { with a considerable reduction in the num- } \\
\text { ber of genera. } \\
\text { From Osborn's reviews, cited above, it } \\
\text { appears that many of Marsh's species are }\end{array}$ \\
\hline Laramie of Wyoming. & An upper fragmentary molar. & $\begin{array}{l}\text { Marsh, Am. Jour. Sci., 3d ser., } \\
\text { vol. } 38 \text {, pp. } 81-90,1889 .\end{array}$ & $\begin{array}{l}\text { synonyms or are established on inadequate } \\
\text { material, and that the list should be greatly } \\
\text { reduced. }\end{array}$ \\
\hline Laramie of Wyoming. & $\begin{array}{l}\text { Fourth premolar of the lower } \\
\text { jaw. Two incisors, prob- } \\
\text { ably from the same spe- } \\
\text { cies, are also represented. }\end{array}$ & $\begin{array}{l}\text { Marsh, Am. Jour. Sci., 3d ser., } \\
\text { vol. } 38, \text { pp. } 81-90,1889 .\end{array}$ & $\begin{array}{l}\text { writer J. W. Gidley refers } 12 \text { of these species } \\
\text { to Ptilodus and } 7 \text { to Meniscoessus and } \\
\text { states that } 7 \text { are uncertain, leaving } 9 \text { species } \\
\text { as probably determined correctly by } \\
\text { Marsh. }\end{array}$ \\
\hline Laramie of Wyoming. & A lower molar. & $\begin{array}{l}\text { Marsh, Am. Jour. Sci., } 3 \mathrm{~d} \text { ser., } \\
\text { vol. } 38 \text {, pp. } 81-90,1889 .\end{array}$ & Marsn. \\
\hline Laramie of Wyoming. & $\begin{array}{l}\text { A scapula, with which are as- } \\
\text { sociated several parts of a } \\
\text { skeleton and fragments of } \\
\text { teeth. }\end{array}$ & $\begin{array}{l}\text { Marsh, Am. Jour. Sci., 3d ser., } \\
\text { vol. } 38, \text { pp. } 81-90,1889 .\end{array}$ & . \\
\hline Laramie of Wyoming. & $\begin{array}{l}\text { A lower jaw which does not } \\
\text { show the number or form } \\
\text { of the teeth. }\end{array}$ & $\begin{array}{l}\text { Marsh, Am. Jour. Sci., } 3 \mathrm{~d} \text { ser., } \\
\text { vol. } 38, \text { pp. } 81-90,1889 .\end{array}$ & \\
\hline Laramie of Wyoming. & $\begin{array}{l}\text { Several teeth and parts of the } \\
\text { skeleton. }\end{array}$ & $\begin{array}{l}\text { Marsh, Am. Jour. Sci., } 3 \mathrm{~d} \text { ser., } \\
\text { vol. } 38, \text { pp. } 81-90,1889 .\end{array}$ & \\
\hline Laramie of Wyoming. & $\begin{array}{l}\text { A number of teeth, of which } \\
\text { the lower molar is taken as } \\
\text { the type. }\end{array}$ & $\begin{array}{l}\text { Marsh, Am. Jour. Sci., } 3 \mathrm{~d} \text { ser., } \\
\text { vol. } 38 \text {, pp. } 81-90,1889 .\end{array}$ & \\
\hline Laramie of Wyoming. & $\begin{array}{l}\text { Several teeth, of which the } \\
\text { lower molar is taken as the } \\
\text { type. }\end{array}$ & $\begin{array}{l}\text { Marsh, Am. Jour. Sci., } 3 \text { d ser., } \\
\text { vol. } 38, \text { pp. } 81-90,1889 .\end{array}$ & \\
\hline
\end{tabular}


TABLE 6.-Geologic distribution of vertebrates in the Belly River, Judith River, Lance

\begin{tabular}{|c|c|c|c|c|c|c|c|c|}
\hline Species. & $\begin{array}{c}1 \\
\begin{array}{c}\text { Belly } \\
\text { Riverfor- } \\
\text { mation. }\end{array}\end{array}$ & $\begin{array}{c}2 \\
\text { Judith } \\
\begin{array}{c}\text { Riverfor- } \\
\text { mation. }\end{array}\end{array}$ & $\begin{array}{c}3 \\
\text { "Hell } \\
\text { Creek } \\
\text { beds" } \\
\text { (Lance } \\
\text { forma- } \\
\text { tion), } \\
\text { Montana. }\end{array}$ & $\begin{array}{c}\mathbf{4} \\
\\
\text { Lance } \\
\text { for- } \\
\text { mation, } \\
\text { Wy- } \\
\text { oming. }\end{array}$ & $\begin{array}{c}\mathbf{5} \\
\text { "Lara- } \\
\text { mie"'for- } \\
\text { mation, } \\
\text { Black } \\
\text { Buttes, } \\
\text { Wy- } \\
\text { oming. }\end{array}$ & $\begin{array}{c}6 \\
\text { Denver } \\
\text { and Arap- } \\
\text { ahoe for- } \\
\text { mations, } \\
\text { Colorado. }\end{array}$ & Finder. & Date. \\
\hline MAMMALIA-conti & & & & & & & & \\
\hline Cimolestes incisus Marsh. & & & & $x$ & & & Hatcher ....... & \\
\hline Cimolestes curtus Marsh. & & & & $x$ & & & Hatcher ...... & \\
\hline Pediomys elegans Marsh. & & & & $x$ & & & Hatcher... & \\
\hline Cimolomys digona Marsh & & & & $\times$ & & & Hatcher...... & \\
\hline Selenacodon brevis Marsh & & & & $x$ & & & Hatcher ..... & \\
\hline Stagodon tumidus Marsh. & & & & $\times$ & & & Hatcher .. & \\
\hline Stagodon nitor Marsh .... & & & & $\times$ & & & Hatcher... & \\
\hline Stagodon validus Marsh.. & & & & $x$ & & & Hatcher ... & \\
\hline Oracodon anceps Marsh. . & & & & $x$ & & & Hatcher ... & \\
\hline Oracodon conulus Marsh. & & & & $x$ & & & Hatcher...... & \\
\hline Allacodon lentus Marsh.. & & & & $x$ & & & Hatcher ..... & \\
\hline Allacodon fortis Marsh.. & & & & $x$ & & & Hatcher ..... & \\
\hline Allacodon pumilus Marsh & & & & $x$ & & & Hatcher ..... & \\
\hline Allacodon rarus Marsh.. & & & & $x$ & & & Hatcher.... & \\
\hline Halodon formosus Marsh. & & & & $x$ & & & Hatcher.... & \\
\hline Cimolodon parvus Marsh & & & & $x$ & & & Hatcher..... & \\
\hline Cimolodon agilis Marsh. & & & & $x$ & & & Hatcher..... & \\
\hline Telacodon præstans Mar & & & & $x$ & & & Hatcher .... & \\
\hline Telacodon lævis Marsh.. & & & & $x$ & & & Hatcher.... & \\
\hline Batodon tenuis Marsh. & & & & $x$ & & & Hatcher.... & \\
\hline
\end{tabular}


("Hell Creek beds" and "Ceratops beds"), and Denver and Araphoe formations-Continued.

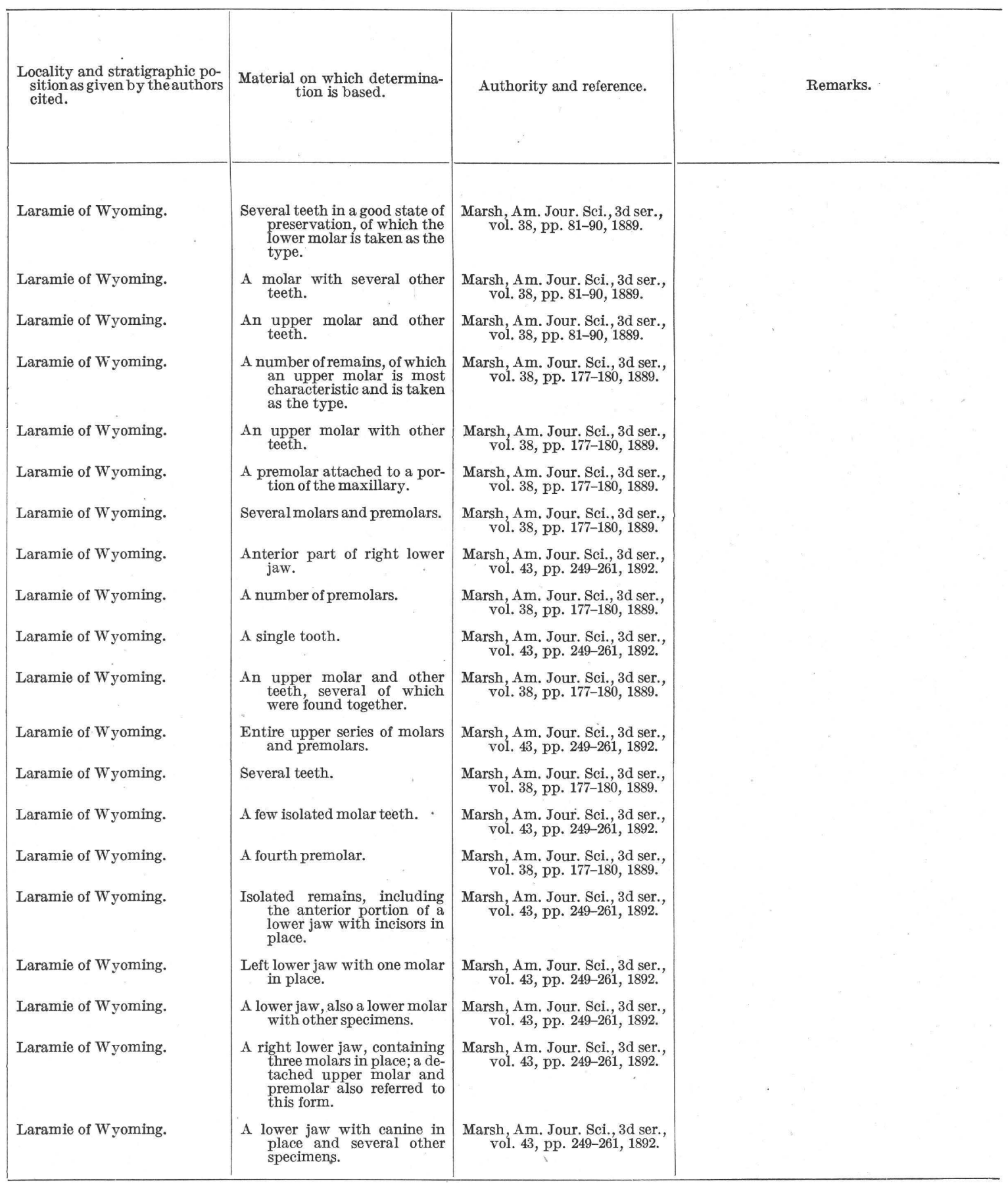


Exclusive of the mammals 135 species are described. In Table 7 are brought together for convenience of comparison all the forms given in Table 6 which have been reported to occur in more than one of the formations involved (the "Hell Creek beds," Lance of Wyoming, and Denver and Arapahoe being considered collectively as "Ceratops beds"). Table 7 therefore shows at a glance the forms common to the Judith River and Belly River, to the Judith River and "Ceratops beds," to the Belly River and "Ceratops beds," and to all three of these formations. It also indicates forms whose specific identification for certain of the formations is in doubt.

TABLE 7.-Species common to two or more of the formations represented in Table 6.

[Specific names in italic indicate doubt as to specific identity of the form from that particular formation. For basis of doubt see Table 6, columns "Material" and "Remarks."]

\begin{tabular}{|c|c|c|}
\hline Belly River formation. & Judith River formation. & "Ceratops beds." $a$ \\
\hline 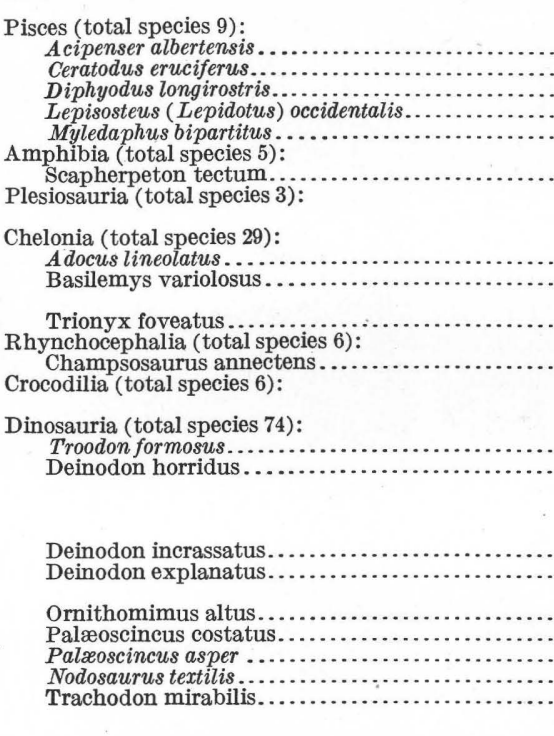 & 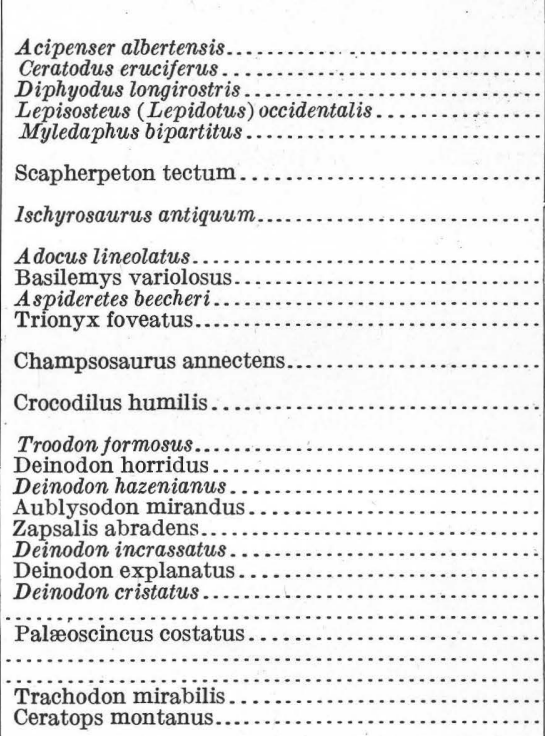 & $\begin{array}{l}\text { Acipenser albertensis. } \\
\text { Diphyodus longirostris. } \\
\text { Lepisosteus (Lepidotus) occidentalis. } \\
\text { Myledaphus bipartitus. } \\
\text { Scapherpeton tectum. } \\
\text { Ischyrosaurus antiquum. } \\
\text { Adocus lineolatus. } \\
\text { Aspideretes beecheri. } \\
\text { Trionyx foveatus. }\end{array}$ \\
\hline
\end{tabular}

$a$ The term "Ceratops beds" is here used to include "Hell Creek beds," Lance formation of Wyoming, and Denver and Arapahoe formation of Table 6.

The forms reported to be common to the "Ceratops beds" and one or both of the other formations are classified as follows:

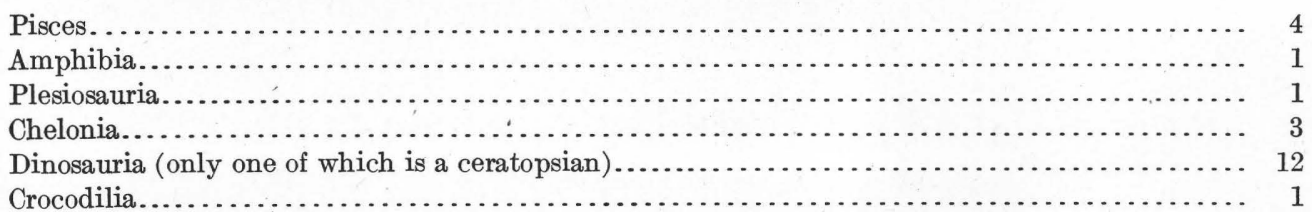

The distribution of these species according to geologic formations is as follows:

Pisces.-Out of 9 species described 5 are common to the Belly River and Judith River, and 4 of these are also common to the "Ceratops beds."

Amphibia.-Of 5 species described there is but 1 that occurs in more than one of the formations, and that 1 is common to the three formations.

Plesiosauria.-Out of 3 species described there are none common to the Belly River and either of the other formations and only 1 common to the Judith River formation and "Ceratops beds."

Chelonia.-Out of 29 species described 3 are common to the Judith River and Belly River, 2 of which are also common to the Lance, and only 1 is common to the Judith River and Lance and not found in the Belly River.

Rhynchocephalia.-Out of 6 species described 1 is common to the Belly River and Judith River, and none are common to either of these formations and the Lance.

Squamata.-No species in common.

Crocodilia.-Of 6 species described 1 is common to the Judith River and the Lance, and none are common to either of these formations and the Belly River. 
Dinosauria.-Of 74 species described 6 are common to the Belly River and Judith River, 7 are common to the Belly River and Lance, and 9 are common to the Judith River and Lance.

Table 8 is introduced for the purpose of showing in a concise way those forms whose specific identification for the localities indicated is doubtful.

TABLE 8.-Species whose identification, from certain formations, is based on inadequate material.

[The type of the species may or may not, however, be based on adequate material.]

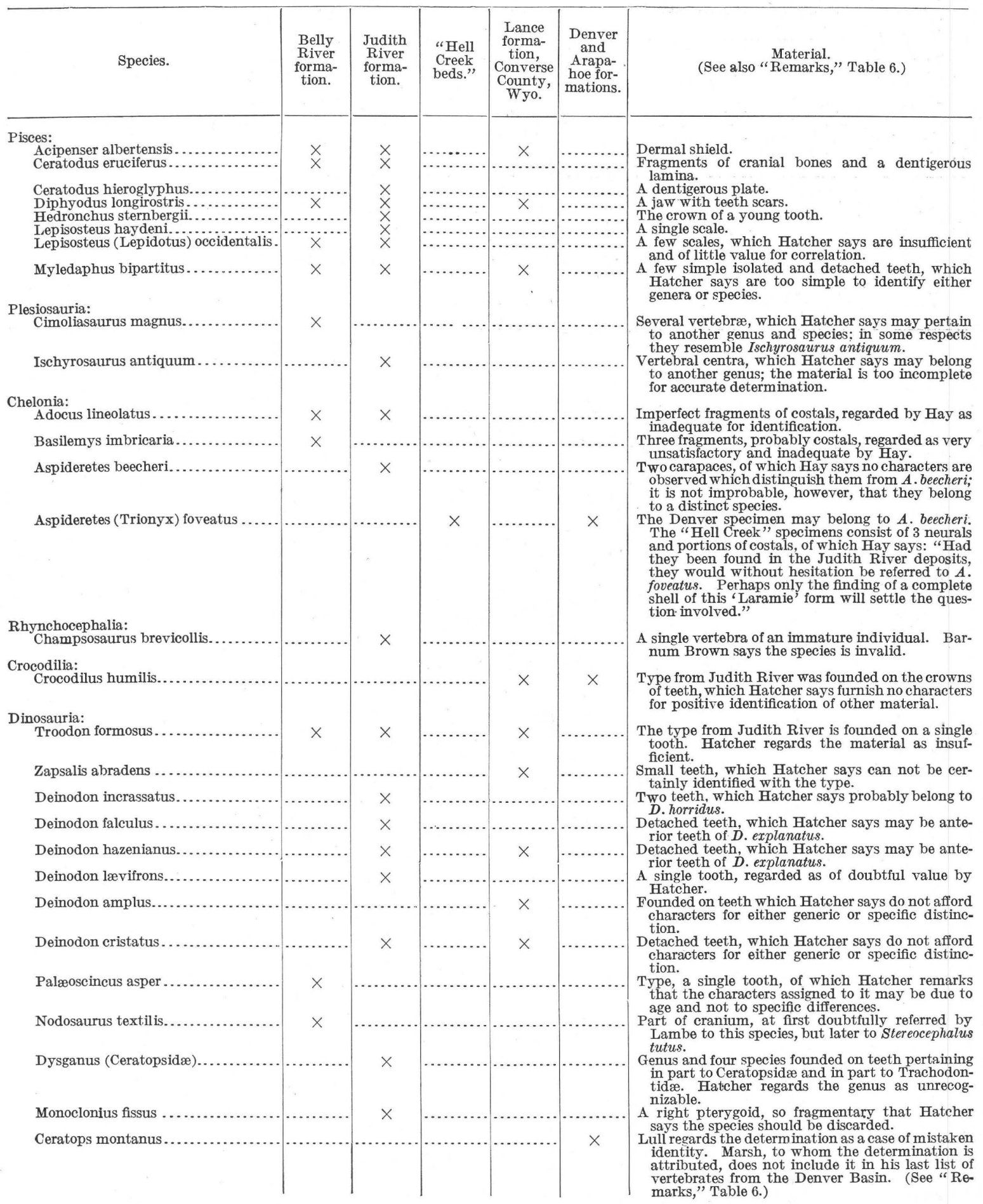


TABLE 8.-Species whose identification, from certain formations, is based on inadequate material-Continued.

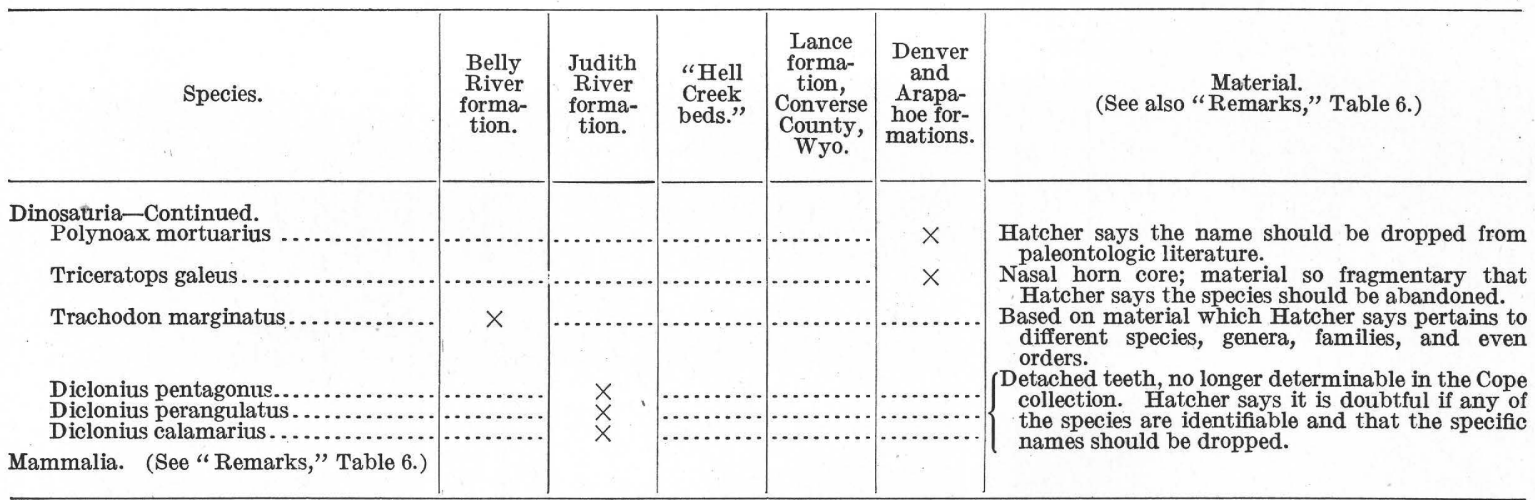

By combining part of the data in Tables 7 and 8, the number of species reported to be common to the several formations and also the number of these forms whose specific identification for either of the formations is doubtful are brought out in Table 9.

TABLE 9.-Number of probably valid and doubtful forms common to the formations represented in Tables 7 and 8.

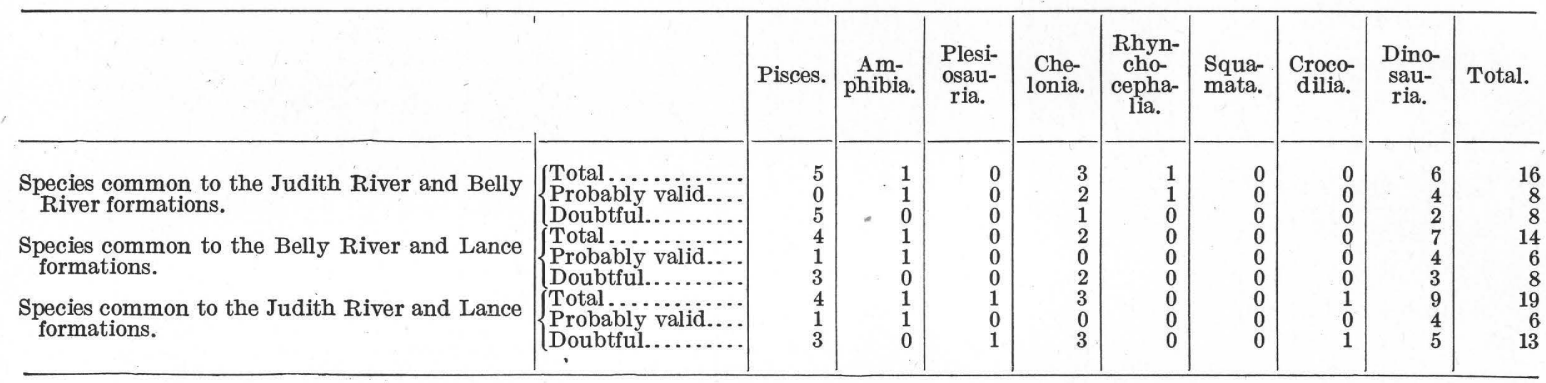

Table 10 gives a list of the species in Table 6 which are based on inadequate material and regarded as of doubtful validity, and Table 11 gives the forms that are probably synonyms.

TABLE 10.-Species whose types are of doubtful validity.

[For basis of doubt, see Table 6, columns "Material" and "Remarks."]

Pisces:

Acipenser albertensis.

Ceratodus eruciferus.

Ceratodus hieroglyphus.

Diphyodus longirostris.

Hedronchus sternbergii.

Lepisosteus occidentalis.

Plesiosauria:

Cimoliasaurus magnus.

Chelonia:

Basilemys imbricaria.

Rhynchocephalia:

Champsosaurus brevicollis.

Crocodilia:

Crocodilus humilis.

Ceratopsidæ:

Dysganus (genera and species).

Monoclonius fissus.

Polynoax mortuarius.

Triceratops galeus.
Trachodontidæ:

Trachodon mirabilis.

Trachodon marginatus.

Diclonius pentagonus.

Diclonius perangulatus.

Diclonius calamarius.

All other Dinosauria:

Troodon formosus.

Deinodon falculus.

Deinodon hazenianus.

Deinodon lævifrons.

Deinodon amplus.

Deinodon cristatus.

Deinodon incrassatus.

Palæoscincus costatus.

Palæoscincus asper. 
TABLE 11.-Forms which are probably synonyms.

[See "Remarks," Table 6.]

\begin{tabular}{|c|c|c|c|c|c|c|}
\hline & $\begin{array}{c}\text { Belly } \\
\text { River } \\
\text { forma- } \\
\text { tion. }\end{array}$ & $\begin{array}{c}\text { Judith } \\
\text { River } \\
\text { forma- } \\
\text { tion. }\end{array}$ & $\begin{array}{l}\text { "Hell } \\
\text { Creek } \\
\text { beds." }\end{array}$ & $\begin{array}{c}\text { Lance } \\
\text { forma- } \\
\text { tion, } \\
\text { Converse } \\
\text { County, } \\
\text { Wyo. }\end{array}$ & $\begin{array}{l}\text { Denver } \\
\text { and Arap- } \\
\text { ahoe } \\
\text { forma- } \\
\text { tions. }\end{array}$ & Authority. \\
\hline 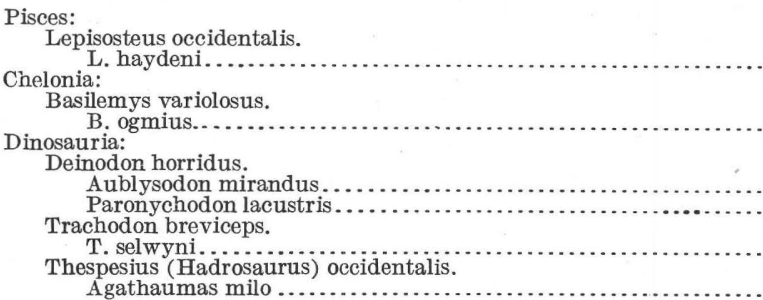 & $\times$ & $\stackrel{x}{x}$ & $\cdots$ & $x$ & $\cdots$ & $\begin{array}{l}\text { Hatcher. } \\
\text { Hay. } \\
\text { Osborn, Lambe. } \\
\text { Hatcher. } \\
\text { Hatcher. } \\
\text { Cope. }\end{array}$ \\
\hline
\end{tabular}

The preceding tables show that there are in all, as identified, 16 species, 8 of which are probably valid, common to the Belly River and Judith River; 14 species, 6 of which are probably valid, common to the Belly River and Lance; and 19 species, only 6 of which are probably valid, common to the Judith River and Lance.

So far as the number of species identified as common to the various formations goes, the vertebrates furnish no more basis for correlating the Judith River and the Lance than for correlating the Belly River and the Lance, but they do show a slight preponderance of evidence in favor of the correlation of the Judith River with the Belly River. On the other band, a study of the generic and specific relationships of the vertebrate faunas from the three formations shows a closer relation between the faunas of the Judith River and the Belly River than between either of these and that of the Lance. This is especially true of the Ceratopsidæ, which form so important an element in the faunas of these three formations and which in the present state of knowledge furnish the most reliable and conclusive evidence of all the vertebrates.

With regard to the Ceratopsidæ, the preceding tables show that with one doubtful exception (Ceratops montanus) there are no species or even genera which are reported as common to the faunas of the Judith River and Belly River on the one hand and the Lance formation on the other; and that there are two genera of the Ceratopsidæ (Ceratops and Monoclonius) which are reported to occur in the Judith River and Belly River formations but not in the Lance, and two genera (Triceratops and Torosaurus) which are reported to occur in the Lance but not in the Judith River or Belly River.

The remarks in Table 6 on Ceratops montanus, which occurs in the Judith River formation and has been reported as occurring in the Denver formation (supposed to be approximately the equivalent of the Lance), show that there is doubt regarding Marsh's identification of the specimen from the Denver formation. Ceratops montanus is therefore not certainly known to occur except in the Judith River formation. With this exception there is not a single instance reported in which Ceratops or Monoclonius has yet been found in the Lance formation, although these genera occur in the Judith River and Belly River formations. Similarly, not a single specimen of Triceratops or Torosaurus has yet been reported from either the Judith River or the Belly River formation, although these genera are abundant in the Lance formation.

It therefore appears that the Ceratopsidæ, which, as stated above, form an important element in the fauna of the Belly River, Judith River, and Lance formations, show a closer generic relationship between the Belly River and Judith River faunas than between either of these faunas and that of the Lance formation. It may be profitable now to consider briefly the genetic relationship of the faunas of the Belly River, Judith River, and Lance formations.

Most if not all paleontologists who are familiar with the faunas of these formations agree that there is a closer genetic relationship between the faunas of the Judith River and Belly River than between the fauna of either of these formations and that of the Lance; also that 
the Belly River and Judith River forms are more primitive than those occurring in the Lance. These conclusions are adequately expressed in the following quotations from Osborn and Hatcher. Osborn ${ }^{1}$ says:

It soon appeared to the writer, in the study of the fine collection made by Mr. Lambe, that the Belly River vertebrates of the Northwest Territory were of decidedly different and apparently of older type than those from the Laramie beds of Converse County, Wyo., described by Marsh, and were rather to be compared with those described by Leidy, Cope, and Marsh, from Montana, chiefly from the Judith River beds, a region by no means distant geographically. * * *

There is thus very little in common between the Belly River fauna and the Laramie fauna of Wyoming and Colorado, so far as described, except the dinosaur Ornithomimus and the very persistent chelonian Baena. Most of the dinosaurs will probably be found to be separated generically.

On the other hand, so far as known, the Montana fauna has much in common with the Belly River, especially the Testudinata, Iguanodontia, and Ceratopsia.

Hatcher's conclusions ${ }^{2}$ are in part as follows:

When considered in its entirety, the vertebrate fauna of these beds [Judith River] is remarkably similar to though distinctly more primitive than that of the Laramie. ***

It is in the Ceratopsidæ more than in any other group that we are at present able to contrast the Judith River and Laramie forms. * * * The primitive nature of the Judith River Ceratopsidæ, as compared with the Laramie, is especially seen in the smaller size of the individuals, the less perfectly developed armature of the skull, and the imperfectly developed parietal crest. ***

Briefly, the Judith River fauna, it is clear, is descended from the Jurassic and is the direct ancestor of the Laramie. Its relations with the former are not close, and several groups are absent in the one which are present in the other. Its relations with the Laramie are much closer, as should be expected, considering the stratigraphic position. With one or two possible exceptions, all the families represented in either of these two later deposits are present also in the other. Although several genera and species now appear to be common to both these formations, it is probable that when more perfect material is available they will be found, in most instances, to be quite distinct, though some pertaining to more persistent types may prove to be identical. In every case where any group of the fauna has been studied from sufficient material it has been found to be represented by distinctly older and more primitive types than the related forms from the Laramie. ${ }^{3}$

In a personal communication to the writer C. W. Gilmore, of the United States National Museum, says:

The more we come to know these faunas the more evidence there is that the Belly River and Judith River species are distinct from those of the Lance formation. If the fauna of the Belly River and Judith River were known from more adequate material, instead of the fragmentary material now at our disposal, the apparent conflicting evidence would no doubt largely, if not entirely, disappear.

A study of the lists of vertebrates reported from the formations under discussion renders one of two conclusions inevitable. Either the vertebrates are of little value for close time correlation or the identification of the stratigraphic horizon or of the material is at fault. As shown in the "Remarks" column of Table 6, many of the identifications have been made on inadequate and insufficient material, and in this connection the comments of so eminent an authority as W. D. Matthew, ${ }^{4}$ which have appeared in print since the tables of this paper were prepared, are of special significance. Matthew says:

Deinodon Leidy is determinable as to family but is not determinable generically, as the genera of carnivorous dinosaurs are now distinguished. The same is true of a whole series of genera and species described by Leidy and Cope from the Judith River. The treatment of types and referred specimens of these genera by paleontologists as specifically distinguishable or identical has sadly misled Dr. Peale in his recent discussion of the vertebrate evidence as to the age of the Judith River beds, leading him to present as conclusive evidence of identity in age a correspondence in fauna, which to those who know the nature of the specimens on which the lists are based is no evidence at all.

It is also possible that there was a confusion of stratigraphic horizons, especially in the assignment of the earlier collections, and until the type area of the Judith River formation (from which most of the vertebrate remains ascribed to that formation have been collected) is mapped in detail on an adequate base of large scale it can not be asserted that all the species

1 Osborn, H. F., Distinctive characters of the mid-Cretaceous fauna: Contr. Canadian Paleontology, vol. 3, pt. 3, pp. 7, $10,1902$.

${ }^{2}$ U. S. Geol. Survey Bull. 257, pp. 101-103, 1905.

C. F. B.

${ }^{3}$ Osborn and Hatcher here used the term "Laramie" for the formation which the United States Geological Survey now calls the Lance.-

${ }^{4}$ Matthew, W. D., The laws of nomenclature in paleontology: Science, new ser., vol. 37, pp. 788-792, May $23,1913$. 
attributed to the formation really belong there. The extensive faulting that has disturbed the strata along Missouri River renders it possible, though it is not extremely probable, that blocks of the Lance formation may be faulted down among the beds of Judith River age and that some of the vertebrates collected by Hayden and others "from the badlands of the Judith" may have been obtained from the Lance formation instead of the Judith River formation, as they supposed.

\section{SUMMARY AND CONCLUSION.}

The stratigraphic and paleontologic evidence as to the position and age of the Judith River formation has been presented in the foregoing pages. It is shown in the discussion of the stratigraphy that the Judith River formation has been traced from areas where its position beneath the Bearpaw shale is undisputed into the western part of the type area (namely, at the mouth of Judith River) and has been found to be identical with the Judith River at that locality. It has also been shown that at some localities along Missouri River, especially on Cow Creek, Stanton and Hatcher found the Judith River formation overlain normally and in flat-lying attitude by the Bearpaw shale, though over most of the area along Missouri River the Bearpaw has been completely eroded. Similar stratigraphic relations between the Judith River and Bearpaw have been observed by the writer between Missouri and Milk rivers in the area lying east of the Bearpaw Mountains.

The paleontologic evidence shows (1) that the marine sandstone of the Claggett formation immediately underlying the Judith River formation at the mouth of Judith River is no more closely allied to the Fox Hills proper than to the underlying Eagle sandstone, and therefore the argument that the Judith River formation overlies the Fox Hills is unfounded; (2) that the flora of the Judith River formation, so far as it has been determined, is of Montana age; (3) that the invertebrates of the Judith River formation are more closely allied to the Belly River than to the Lance; (4) that almost all the vertebrates that are common to the Judith River and Lance are also common to the Belly River and Lance, and hence, if the Judith River is to be made the equivalent of the Lance on the basis of the similarity of the vertebrate fauna, the Belly River must on the same evidence also be made the equivalent of the Lance formation; (5) that the Ceratopsidæ, which form so important an element of the Lance fauna, are generically and specifically unlike the representatives of that family in the Belly River and Judith River faunas.

The evidence of the vertebrate fauna, so far as in the present state of knowledge it has any weight, and the evidence of the fresh and brackish water invertebrates, so far as it is decisive for accurate time determination, indicate a closer relationship between the Belly River and Judith River than between either of these formations and the Lance. This is in accord with the stratigraphic evidence, which shows conclusively that both the Judith River and Belly River formations are separated from the Lance by a marine formation which is of undoubted Cretaceous age. 